RAFAEL DARIOLLI

\title{
Caracterização de células-tronco mesenquimais derivadas do tecido adiposo de porcos criopreservadas e sua responsividade ao Shear stress
}

Dissertação apresentada à Faculdade de Medicina da Universidade de São Paulo para obtenção do título de Mestre em Ciências

Programa: Ciências Médicas

Área de concentração: Distúrbios Genéticos de Desenvolvimento e Metabolismo

Orientador: Prof. Dr. José Eduardo Krieger

São Paulo

2011 
Dados Internacionais de Catalogação na Publicação (CIP)

Preparada pela Biblioteca da

Faculdade de Medicina da Universidade de São Paulo

Creprodução autorizada pelo autor

Dariolli, Rafael

Caracterização de células-tronco mesenquimais derivadas do tecido adiposo de porcos criopreservadas e sua responsividade ao Shear stress / Rafael Dariolli. -São Paulo, 2011.

Dissertação(mestrado)--Faculdade de Medicina da Universidade de São Paulo. Programa de Ciências Médicas. Área de concentração: Distúrbios Genéticos de Desenvolvimento e Metabolismo.

Orientador: José Eduardo Krieger.

Descritores: 1.Células-tronco mesenquimais 2.Shear stress 3.Suínos 4.Criopreservação 5.Tecido adiposo

USP/FM/DBD-281/11 
A meus pais, Odair e Isete, sem os quais e por motivos não tão óbvios, eu jamais teria chegado tão longe. Acima de tudo, por me ensinarem a ter persistência, a qual me impediu de desistir quando tudo parecia perdido. 


\section{Agradecimentos}

Primeiramente, gostaria de agradecer ao Prof. Dr. José Eduardo Krieger, pela a oportunidade, tendo me aceitado como seu aluno, pela confiança a mim depositada e pelos exemplos diários de determinação, dedicação e competência que tem me orientado na formação de meu caráter científico.

Aos funcionários Edna, Sueli, Eduardo, Liliane, Nelson, Richard, Elenice, Pedro, entre outros tantos, da Divisão de Experimentação do InCor, por toda ajuda com os experimentos realizados com os porcos.

Ao Prof. Dr. Luiz Francisco Poli de Figueiredo (in memoriam) e Prof. Dr. Luiz Alberto Soares e os funcionários Santana, Cláudio e Sueli, da Disciplina de Cirurgia da FMUSP pela ajuda com a extração de tecido adiposo dos porcos.

Ao Prof. Dr. Francisco Rafael Martins Laurindo e a Denise, João e Vitor do Laboratório de Biologia Vascular, pelo empréstimo do sistema de cones para Shear Stress e a Laura I. V. Brandizzi pelas dosagens de óxido nítrico no NO Analyser.

A Milena e Carlos do Laboratório de Pleura da Divisão de Pneumologia FMUSP, pelo apoio técnico.

A todos os amigos e colegas do LGCM que de alguma maneira tiveram participação direta ou indireta na realização deste.

À Luciene, Samantha, Thais, Juliana, Valério, Newton, Flávio, Tiago, pela ajuda imensamente importante e indispensável na geração do banco de célulastronco.

À Giovana Gonçalves, a primeira colega de LGCM, por me encorajar sempre em vir fazer o mestrado com Prof. Krieger.

À Ayumi Aurea Miyakawa pelo apoio científico e técnico, discussões enriquecedoras e orientação principalmente no período turbulento da produção do banco de células-tronco.

À Camila Zogbi e Fernando R. Giugni pela ajuda decisiva no final dos protocolos de contagem de tempo de dobramento. 
Ao Márcio Chaves, Arruda e Janilton pelo apoio técnico e a amizade de sempre.

À Juliana Sanajotti Nakamuta e Maria Elena Danoviz, por terem me recebido tão bem, me engajado no grupo de terapia celular e me ensinado todos os meus primeiros passos. Pelas discussões que me ensinaram muito e me permitiram escrever o projeto que deu origem a esse trabalho, pelos conselhos, as correções de trabalhos e relatórios e pela amizade diária.

Ao Vinicius Bassaneze, além de todo o apoio técnico, agradeço, por toda a dedicação, responsabilidade, conhecimentos e exemplos, nos quais tenho me baseado para me tornar um pesquisador competente. A confiança nas minhas tomadas de decisão e o apoio e orientação a cada passo dado. Também pelas experiências de vida, a paciência, a qual, muitas vezes me acalmou não permitindo que eu perdesse a razão.

Ao grande amigo e parceiro de republica Vinicius Melo, por ter me agüentado falando sobre as células-tronco sem parar, pela importante ajuda no começo de tudo no LGCM com a produção de adenovirus e pelas horas de violão, viagens, cervejas, amizade.

Ao Luis Felipe Neves do Santos, um grande amigo que surgiu na hora certa para ajudar de forma considerável no manejo com os porcos e muito, além disso, por me fazer lembrar os grandes amigos que já fiz nessa vida, cultivando uma amizade que não se limita apenas as paredes de nossos laboratórios.

À Gabriela Venturini, pelo apoio científico e técnico, sem os quais essa trajetória teria sido muito mais tortuosa. Você me ajudou a equilibrar tudo desde primeira lista de atividades até meus sentimentos e atitudes profissionais fazendo com que eu me tornasse um profissional mais eficiente, acessível e tolerável. Acima de tudo pelas várias discussões, trocas de experiência, amizade, companheirismo, paciência, dedicação e carinho que tem tido diariamente com este seu colega de laboratório e namorado.

A meus pais, Odair e Isete pela incansável dedicação que tiveram em me dar educação, bons modos e respeito, principalmente com o que é diferente. Pela infinita segurança e apoio que me deram sempre que resolvi enfrentar novos desafios e mudanças de trajetória, somada a implacável fé e confiança 
em minhas decisões e escolhas. A minha irmã Nicole que com sua sinceridade de sempre me fez enxergar mais longe colaborando para formação de meu caráter.

Este trabalho foi elaborado com financiamento da Agência de Fomento à pesquisa CNPq (Conselho Nacional de Desenvolvimento Científico e Tecnológico). 
Esta dissertação está de acordo com as seguintes normas, em vigor no momento desta publicação:

Referências: adaptado de International Committee of Medical Journals Editors (Vancouver)

Universidade de São Paulo. Faculdade de Medicina. Serviço de Biblioteca e Documentação. Guia de apresentação de dissertações, teses e monografias. Elaborado por Anneliese Carneiro da Cunha, Maria Julia de A. L. Freddi, Maria F. Crestana, Marinalva de Souza Aragão, Suely Campos Cardoso, Valéria Vilhena. 2a ed. São Paulo: Serviço de Biblioteca e Documentação; 2005.

Abreviaturas dos títulos dos periódicos de acordo com List of Journals Indexed in Index Medicus. 


\section{Sumário}

Lista de Abreviações................................................................................

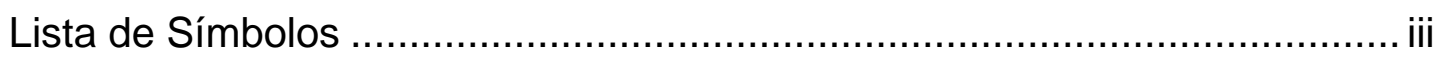

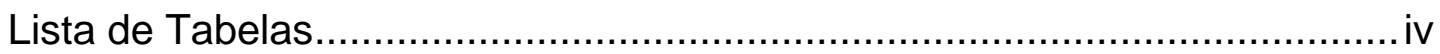

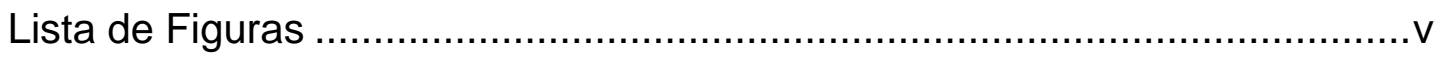

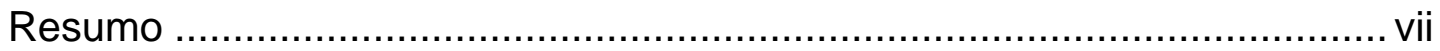

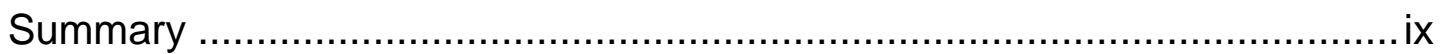

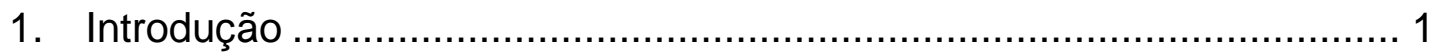

1.1. Células-tronco Adultas - Renovação e Manutenção dos Tecidos ...............3

1.2. O Tecido Adiposo - Uma Fonte de Células-Tronco Mesenquimais ............5

1.3. Banco de Células-Tronco - Perfil Imunológico e Criopreservação.............. 7

1.4. O Shear stress, Células-Tronco e o Reparo Cardíaco ...............................8

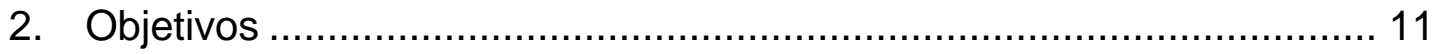

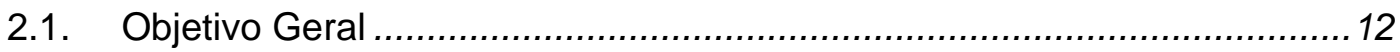

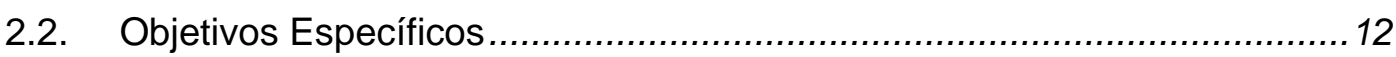

3. Materiais e Métodos ......................................................... 13

3.1. Isolamento, expansão e congelamento ex vivo de pASC ........................14

3.2. Citometria de Fluxo - Marcadores de superfície de pASC .....................16

3.3. Elaboração das Curvas de Crescimento Populacional das pASC .............17

3.4. Determinação do Tempo de Dobramento (TD) Populacional - pASC ........18

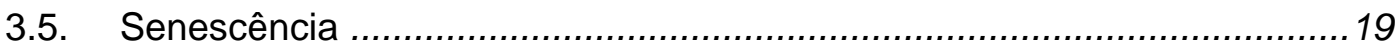

3.6. Diferenciação de pASC por Indução Química ........................................20

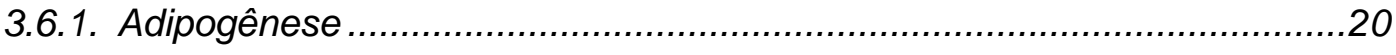

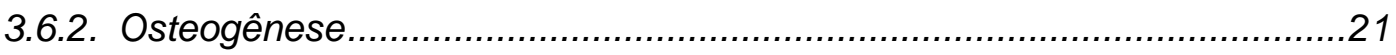

3.7. Experimentos com shear stress - Diferenciação por Estímulo Físico.......22

3.7.1. Determinação da Produção de Óxido Nítrico (NO).................................25

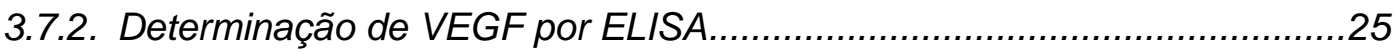


3.7.3. Análise protéica - Extração, eletroforese e Western Blotting .27

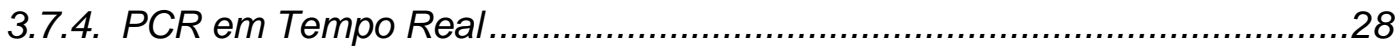

3.7.5. Extração do ácido ribonucléico (RNA) ...............................................28

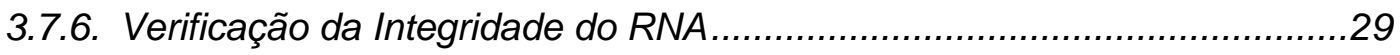

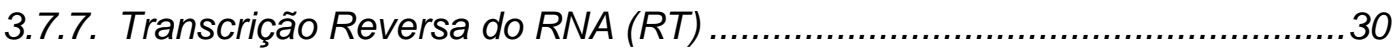

3.7.8. Reação em Cadeia da Polimerase (PCR) - qRT-PCR ........................... 30

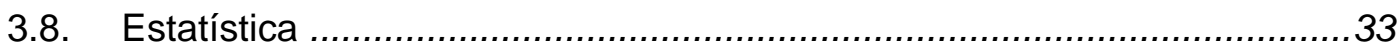

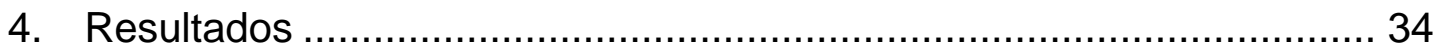

4.1. Caracterização das Células Mesenquimais de Tecido Adiposo de Porcos (pASC) - Gerando um Banco de Células ............................................................35

4.2. Isolamento, Expansão e Congelamento ex vivo de pASC........................35

4.3. Viabilidade das pASC Após Descongelamento e Entre Passagens..........37

4.4. Marcadores de Superfície - Imunofenótipo Mesenquimal........................38

4.5. Cinética de Crescimento das pASC ....................................................41

4.5.1. Tempo de Dobramento ................................................................. 41

4.5.2. Índice de dobramento populacional cumulativo (IDPC) .........................42

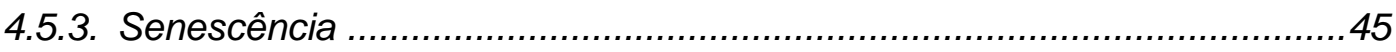

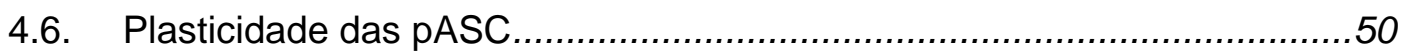

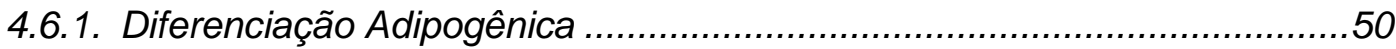

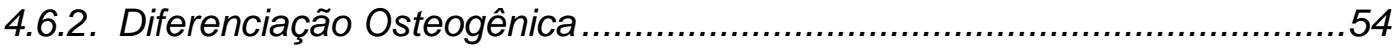

4.7. Experimentos com shear stress......................................................56

4.7.1. Análise Morfológica de pASC - Alinhamento Celular ..............................56

4.7.2. Análise de Marcadores Endoteliais em pASC Submetidas ao SS.............58

4.7.3. Dosagem de NO em pASC submetidas ao SS ....................................60

4.7.4. Dosagem de VEGF em pASC submetidas ao SS ...............................63

4.7.5. Avaliação da Fosforilação de ERK e AKT em pASC Submetidas a Curto Período de SS .66

4.7.6. Dosagem de NO e VEGF em pASC submetidas a Diferentes Magnitudes de SS 69 


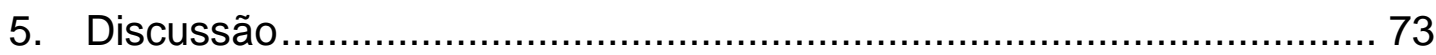

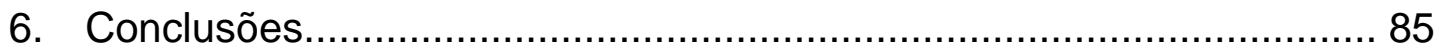

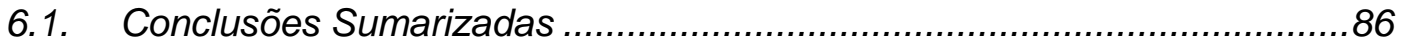

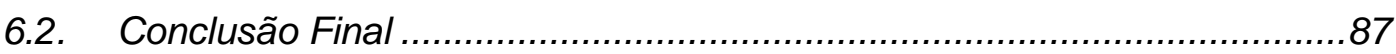

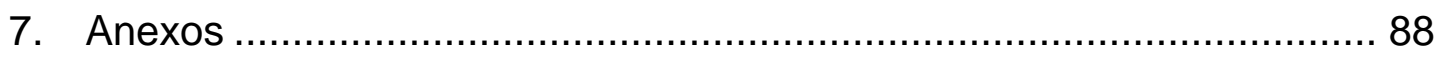

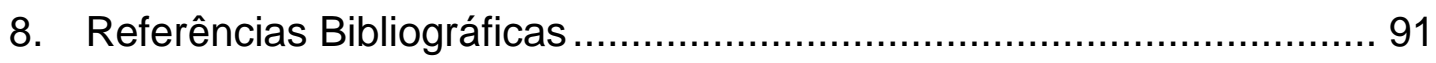
Apêndices 


\section{Lista de Abreviações}

\begin{tabular}{|c|c|}
\hline ARS & - do inglês, Alizarin Red S \\
\hline ASC & - do inglês, Adipose derived stem cell \\
\hline BM-MSC & - do inglês, Bone marron mesenchymal stem cell \\
\hline BSA & - do inglês, Bovine serum albumin \\
\hline CAPPesq & - Comissão de Ética para Análise de Projetos de Pesquisa \\
\hline cASC & - do inglês, Canine ASC \\
\hline CD29 & - Cluster de diferenciação 29 \\
\hline CD31 & - Cluster de diferenciação 31 \\
\hline CD44 & - Cluster de diferenciação 44 \\
\hline CD90 & - Cluster de diferenciação 90 \\
\hline CDNA & - DNA complementar \\
\hline $\mathrm{CO}_{2}$ & - Dióxido de carbono \\
\hline Ctrl & - Controle \\
\hline DEPC & - Dietileno pirocarbonato \\
\hline DMEM & - do inglês, Dulbecco's Modified Eagle Medium \\
\hline DMEM-Low & - do inglês, Dulbecco's Modified Eagle Medium with Low glucose \\
\hline DMSO & - Dimetilsulfóxido \\
\hline DNA & - do inglês, Deoxyribonucleic acid \\
\hline dNTP's & - Desoxirribonucleotídeos fosfatados \\
\hline ECA & - Enzima Conversora de Angiotensina \\
\hline ECGS & - do inglês, Endothelial cell growth supplement \\
\hline ECL & - do inglês, Enhanced chemiluminescence \\
\hline EDTA & - Ácido etilenodiamino tetra-acético \\
\hline EGM-2 & - do inglês, Endothelial Cell Growth Medium-2 \\
\hline EGTA & - Ácido Etilenoglicol tetra-acético \\
\hline ELISA & - do inglês, Enzyme Linked Immunosorbent Assay \\
\hline eNOS & - do inglês, Endothelial Nitric Oxide Synthase \\
\hline FLK-1 & - do inglês, Fetal Liver Kinase-1 \\
\hline Flt-1 & - do inglês, Fms-Related Tyrosine Kinase 1 \\
\hline FMUSP & - Faculdade de Medicina da Universidade de São Paulo \\
\hline $\mathrm{H}_{2} \mathrm{O}_{2}$ & - Peróxido de Hidrogênio \\
\hline $\mathrm{H}_{2} \mathrm{SO}_{4}$ & - Ácido sulfúrico \\
\hline $\mathrm{H}_{3} \mathrm{PO}_{4}$ & - Ácido fosfórico \\
\hline hASC & - do inglês, Human ASC \\
\hline HEPES & - Ácido 4-(2-hidroxietil)-1-piperazineetanesulfonico \\
\hline HRP & - do inglês, Horseradish Peroxidase \\
\hline $\mathrm{Hs}$ & - Horas \\
\hline IBMX & - 3-isobutil-1-metilxantina \\
\hline IM & - Infarto do miodárdio \\
\hline iNOS & - do inglês, Inducible Nitric Oxide Synthase \\
\hline $\mathrm{KCl}$ & - Cloreto de potássio \\
\hline KDR & - do inglês, Kinase Insert Domain Receptor \\
\hline LDL & - do inglês, Low Density Lipoprotein \\
\hline L-NAME & - L-NG-Nitroarginina metil éster \\
\hline
\end{tabular}




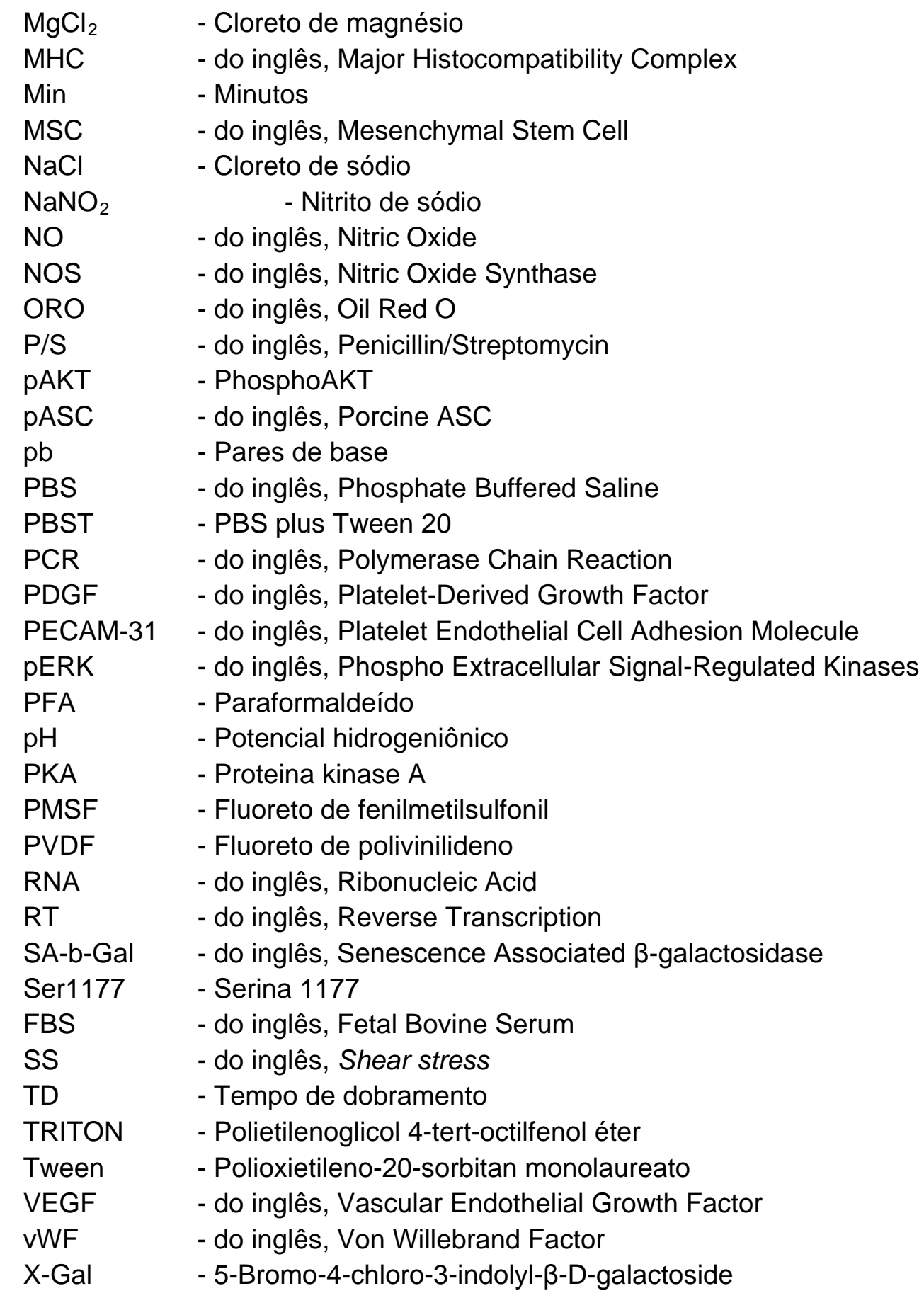




\section{Lista de Símbolos}

$\begin{array}{ll}\text { dyn/cm² } & \text { - Dinas por centímetro quadrado } \\ \mathrm{g} & \text { - Gramas } \\ \mathrm{G} & \text { - Giros } \\ \mathrm{kDa} & - \text { Kilo daltons } \\ \mathrm{M} & - \text { Molar } \\ \mathrm{mg} & - \text { Miligrama } \\ \mathrm{mL} & - \text { Mililitro } \\ \mathrm{mM} & - \text { Milimolar } \\ \mathrm{ng} & - \text { Nanograma } \\ \mathrm{nm} & - \text { Nanômetro } \\ \mu \mathrm{g} & - \text { Micrograma } \\ \mu \mathrm{L} & - \text { Microlitro } \\ \mu \mathrm{M} & - \text { Micromolar } \\ \alpha & - \text { Ângulo de inclinação do cone em relação a placa de cultura } \\ \omega & - \text { Radianos/segundo }\end{array}$




\section{Lista de Tabelas}

Tabela 1: Marcadores Imunofenotípicos de Superfície de ASC versus BMMSC.

Tabela 2: Primers usados para RT-PCR e qRT-PCR 32

Tabela 3: Caracterização imunofenotípica de pASC em passagens 4 e 5, antes ou após serem submetidas a congelamento. 40 


\section{Lista de Figuras}

Figura 1: Sistema de "Cone-plate"

Figura 2: Morfologia de pASC Antes e Após Congelamento

Figura 3: Viabilidade após descongelamento e entre passagens de pASC. 38

Figura 4: Homogeneidade da população de pASC

Figura 5: Histograma representativo para marcadores avaliados por citometria de fluxo.

Figura 6: Marcadores Mesenquimais de Superfície das pASC

Figura 7: Tempo de dobramento das pASC

Figura 8: Índice de Dobramento Populacional Cumulativo (IDPC) de pASC em função do tempo em dias de cultura.

Figura 9: Índice de Dobramento Populacional Cumulativo (IDPC) médio de pASC em função do tempo em dias de cultura.

Figura 10: Índice de Dobramento Populacional Cumulativo (IDPC) médio de pASC em função das passagens 45

Figura 11: Senescência de pASC - Teste Citoquímico de SA- $\beta-G a l$ 46

Figura 12: Controle positivo para senescência em pASC - Indução com $\mathrm{H}_{2} \mathrm{O}_{2}$

Figura 13: Senescência de pASC passagem 5 até 10.

Figura 14: Gráfico de Regressão Linear para Senescência media de pASC em função das passagens

Figura 15: pASC induzidas com meio de diferenciação para linhagem adipogênica.

Figura 16: Linhagem adipogênica após protocolos de coloração com ORO 52 
Figura 17: Diferença no diâmetro das vesículas lipídicas de hASC VS. pASC

Figura 18: Organização em forma de crista de pASC após indução para linhagem osteogênica

Figura 19: pASC induzidas com meio de diferenciação para linhagem osteogênica 55

Figura 20: Morfologia de pASC após 48 horas de shear stress. 57

Figura 21: Gráfico de Tamanho (FSC) em função da granulosidade (SSC) 58

Figura 22: Análise de marcadores mesenquimais e endoteliais para pASC 60

Figura 23: Shear stress induz a liberação de NO em pASC

Figura 24: Shear stress induz a liberação de NO em pASC e esta não é bloqueada por L-NAME após 24 horas de estímulo 62

Figura 25: L-NAME bloqueia a atividade de NOS sob Shear stress reduzindo a liberação de NO em pASC 63

Figura 26: Shear stress induz a liberação de VEGF em pASC. 65

Figura 27: Shear stress induz a liberação de VEGF mediado por NO em pASC 66

Figura 28: Pico de fosforilação de ERK e AKT em pASC submetidas a SS 67

Figura 29: Fosforilação de ERK em pASC submetidas a SS 68

Figura 30: Fosforilação de AKT em pASC submetidas a SS 69

Figura 31: Diferentes intensidades de Shear stress de curta duração não alteram a liberação de NO em pASC 70

Figura 32: Diferentes intensidades de Shear stress de longa duração induzem diferentes níveis de liberação de NO e VEGF em pASC. 


\section{Resumo}

Dariolli R. Caracterização de células-tronco mesenquimais derivadas do tecido adiposo de porcos criopreservadas e sua responsividade ao Shear stress [dissertação]. São Paulo: Faculdade de Medicina, Universidade de São Paulo; 2011.

As células-tronco mesenquimais derivados do tecido adiposo (ASC) apresentam potencial para uso em terapêuticas para reparação cardíaca e o modelo de suínos recapitula aspectos relevantes dos seres humanos. Nesta dissertação quisemos caracterizar ASC de porcos (pASC), após criopreservação e avaliar a responsividade destas células ao shear stress. Após descongelamento as pASC exibiram 90-95\% de viabilidade, não apresentaram alterações morfológicas e nem na expressão de marcadores de superfície (CD29+ 99,74\% $\pm 0,10 ; \quad C D 90+97,84 \% \pm 1,32 ; \quad C D 44+$ $99,39 \% \pm 0,19$, CD31- $1,75 \% \pm 0,21 ; \quad$ média $\pm E P M, \quad n=3)$. O tempo de dobramento médio foi de $63,51 \pm 16,46$ horas (média $\pm D P$ ) e o dobramento populacional cumulativo aumentou constantemente até a passagem 10 , com pequeno e gradual aumento na senescência (P5 3,25\% $\pm 0,26$ e P10 $9,6 \% \pm 0,29$ SA- $\beta$-Gal). Além disso, as pASC responderam, in vitro, ao tratamento para diferenciação em adipócitos e osteócitos. Já a exposição ao SS (15 dyn $/ \mathrm{cm}^{2}$ por $48 \mathrm{hs}$ ) não induziu a expressão de marcadores endoteliais (CD31, VE-caderina e FLK-1), mas resultou no acúmulo de VEGF induzido por NO (15 dyn/ $/ \mathrm{cm}^{2}$ por $96 \mathrm{hs}$ ). Interessantemente, o SS induziu a fosforilação de ERK e AKT e a liberação de NO independente da magnitude do SS (1-30 dyn/ $\mathrm{cm}^{2}$, por $30 \mathrm{~min}$ ). No entanto, longos períodos de 
estímulo (24-48 hs) e diferentes intensidades de shear stress induziram desigualmente a liberação de NO e VEGF (5 dyn/cm² maior do que 10 ou 15 dyn/ $\mathrm{cm}^{2}$ ). Tomados em conjunto, nossos dados promovem evidências de que a viabilidade, morfologia, cinética de crescimento e resposta a estímulos químicos ou físicos de pASC não foram influenciados pela criopreservação. Além disso, a magnitude de SS aplicada a essas células afetou a liberação de NO e VEGF somente após longos períodos de exposição a esse estímulo.

Descritores: Células-tronco mesenquimais; Shear stress; Suínos; Criopreservação; Tecido Adiposo. 


\section{Summary}

Dariolli R. Characterization of cryopreserved porcine adipose-derived mesenchymal stem cells and responsiveness to shear stress [dissertation]. São Paulo: "Faculdade de Medicina, Universidade de São Paulo"; 2011.

Adipose tissue-derived mesenchymal stem cells (ASC) offer potential regenerative therapeutic application for cardiac repair and the porcine model recapitulates key aspects relevant to humans. In this dissertation we wanted to establish the culture characteristics of pig ASC (pASC), especially after long-term cryopreservation and the effect of shear-stress (SS)-induced phenotypes. Upon thawing, pASC displayed 90-95\% viability and no changes in morphological characteristics or in the expression of surface markers (CD29+ 99.74\% $\pm 0.10 ; C D 90+97.84 \% \pm 1.32 ; C D 44+99.39 \% \pm 0.19$, CD31$1.75 \% \pm 0.21$; mean $\pm S E M, n=3$ ). Mean population doubling time was $63.51 \pm 16.46$ hours (mean $\pm S D$ ) and cumulative population doubling increased constantly until passage 10 with a small and gradual increase in senescence (P5 3.25\% \pm 0.26 and P10 9.6\% \pm 0.29 SA- $\beta-G a l$ staining). In addition, pASC in vitro responded to adipogenic and osteogenic chemical cues, whereas SS exposure (15 dyn/ $/ \mathrm{cm}^{2}$ up to 48 hours) failed to induce endothelial cell (EC) markers (CD31, VE-cadherin and FLK-1), but resulted in nitric oxide (NO)-induced VEGF accumulation (15 dyn/ $\mathrm{cm}^{2}$ up to 96 hours). Interestingly, SS-induced phosphorylation of ERK and AKT and the release of NO were independent of the magnitude of the stimulus (1-30 dyn/ $/ \mathrm{cm}^{2}$, up to 30minutes). In contrast, long term (24-48 hours) SS-induced NO and 
VEGF release under $5 \mathrm{dyn} / \mathrm{cm}^{2}$ were higher than 10 or $15 \mathrm{dyn} / \mathrm{cm} 2$. Altogether, we provided evidence that pASC cell viability, morphology, growth characteristics and capacity to respond to chemical or physical cues were not influenced by cryopreservation. Moreover, the magnitude of the SS affected the NO and VEGF release in pASC only during long-term exposure to SS.

Descriptors: Mesenchymal Stem Cells; Shear stress; Swine; Cryopreservation; Adipose Tissue. 
1. Introdução 
Introdução

As doenças cardiovasculares são a principal causa de morte em todo o mundo, dentre elas, o infarto do miocárdio (IM) é considerado a patologia mais comum. Estudos epidemiológicos realizados no ano de 2005 registraram 17,5 milhões de óbitos devido a doenças cardiovasculares, 0 que representa cerca de $30 \%$ da população mundial. Destes, 7,6 milhões morreram em decorrência de IM (1). Segundo dados do Ministério da Saúde, no Brasil as doenças do aparelho circulatório somam $28,20 \%$ das doenças causadoras de morte, das quais, 29,92\% referem-se às doenças isquêmicas do coração (2).

Avanços significativos têm sido observados nas últimas décadas no desenvolvimento de tratamentos para doenças cardíacas oclusivas como a utilização de medicamentos e técnicas de revascularização cirúrgica ou por angioplastia. Contudo, o grande desafio continua sendo como evitar o remodelamento ventricular e a falência cardíaca decorrentes da perda tecidual que se segue ao infarto do miocárdio. Buscando resolver esse desafio, estudos recentes têm testado terapias alternativas como o uso de células-tronco para a recuperação de tecidos lesados, por exemplo, por isquemia, e diferentes mecanismos para explicar a melhora da função cardíaca observada tem sido demonstrados (3-10).

Algumas poucas evidências suportam a idéia de que as células-tronco são capazes de se diferenciar em cardiomiócitos adultos e repovoar o músculo cardíaco isquêmico $(11,12)$. Um maior número de evidências aponta para um efeito secundário, oriundo de atuação parácrina destas células, através da liberação de fatores de crescimento, fatores anti- 
Introdução

apoptóticos e pró-angiogênicos que podem colaborar para uma melhora no microambiente cardíaco $(9,10,13-15)$.

Estudos pré-clínicos, principalmente utilizando modelos de roedores, têm apresentado resultados promissores $(9,10,16)$, porém para que estas terapias possam ser aplicadas com segurança e efetividade no homem, fazem-se necessários estudos em modelos animais mais apropriados para possíveis extrapolações. Neste sentido, o modelo de suínos apresenta grande potencial para cardiologia experimental, visto que este é um animal de grande porte com características anatômicas e fisiológicas muito próximas as de um humano $(17,18)$. Contudo, assim como para roedores, as células-tronco de porcos precisam ser mais bem estudadas para que se possam conhecer suas características e perfis de expressão imunofenotípicos, gênicos, protéicos, frente aos mais diversos estímulos, tanto em estudos in vitro como em terapia experimental.

\subsection{Células-tronco adultas - renovação e manutenção dos tecidos}

Devido a questões éticas e políticas, além das dificuldades para isolamento e o elevado risco da formação de teratomas e teratocarcinomas em aplicações in vivo, $(19,20)$ células-tronco embrionárias, a despeito de toda sua capacidade plástica (21), ainda tem sido pouco exploradas para fins terapêuticos.

Por outro lado, é bem conhecido que em quase todos os tecidos de um organismo há constante substituição celular, sobretudo através da diferenciação de células-tronco residentes. Essas células podem ser 
Introdução

encontradas nos diferentes estágios da vida e, exceto em casos de dano tecidual, se dividem em baixa frequência apenas para manutenção de uma população de reserva nos tecidos. Por isso, tecidos adultos têm sido muito explorados como fonte para obtenção de células-tronco, visto que praticamente todos eles apresentam células-tronco residentes (22).

Uma característica interessante e inerente a essas células é seu alto grau de plasticidade, de forma que são capazes de gerar células maduras de órgãos distintos (23). Apesar desta plasticidade, estas células parecem não dar origem a tumores quando injetadas $(9,10,16)$ e ainda, em determinados casos, promover a manutenção das células viáveis ou ainda regeneração de tecidos lesados $(24,25)$.

Dentre as células-tronco adultas mais exploradas no contexto da reparação de tecidos estão as de origem mesenquimal (do inglês, MSC) (11, 26). Estas células apresentam diversos marcadores de superfície que em conjunto qualificam este tipo celular. Dentre estes, o CD29 ou integrina beta1, uma proteína heterodimérica responsável principalmente pela adesão celular, é um marcador amplamente utilizado na sua caracterização. Outro marcador de superfície característico dessas células também relacionado com a adesão é o CD90 ou Thy-1 (27-30).

Estas células têm como principal apelo para aplicações clínicas sua plasticidade, facilidade de isolamento, facilidade de cultivo e alta viabilidade em culturas in vitro $(31,32)$. 
Introdução

\subsection{O tecido adiposo - uma fonte de células-tronco mesenquimais}

Estudos pioneiros com células-tronco utilizavam como fonte a medula óssea $(12,33,34)$ devido a oportunidade ética proporcionada pelos transplantes de medula óssea em pacientes com leucemia. No entanto, as pesquisas têm demonstrado ao longo dos anos que a medula óssea apresenta algumas limitações.

A medula óssea é uma fonte de células-tronco heterogênea composta principalmente por células-tronco hematopoiéticas com capacidade de regeneração tecidual por longo período de tempo, células-tronco hematopoiéticas com capacidade de regeneração tecidual por curto período de tempo, células progenitoras, além de células-tronco mesenquimais não hematopoiéticas (33-36).

Apesar da possibilidade de obtenção de células-tronco mesenquimais da medula (do inglês, BM-MSC), o isolamento destas células tem como resultado uma população ainda heterogênea, de difícil manutenção em cultura e pobre em quantidade de células mesenquimais (37), além de os procedimentos de isolamento causarem ao paciente desconforto e dor (3739). Por isso, em um contexto de facilidades e rentabilidade, ao longo dos anos o foco sobre as células-tronco de medula tem sido dividido com outras fontes de células.

Com essa divisão de atenções, dentre as fontes mais exploradas está o tecido adiposo, o qual demonstra elevado potencial para o uso terapêutico de células-tronco. Neste tecido é possível isolar uma população homogênea e abundante de células-tronco mesenquimais facilmente cultiváveis (37). As 
Introdução

células-tronco mesenquimais derivadas do tecido adiposo (do inglês, ASC) foram isoladas pela primeira vez em tecido adiposo humano (hASC) através de lipoaspirado resultante de cirurgia plástica estética (40), um procedimento muito menos desconfortável, doloroso e arriscado que a extração de medula óssea. As hASC foram capazes, por longos períodos em cultura, de se manter sem perda de estabilidade do dobramento populacional e com alta capacidade de diferenciação em múltiplas linhagens celulares $(23,39)$.

Estudos comparativos, bem revisados por Fraser e colaboradores, entre ASC e MSC demonstraram que o padrão fenotípico antigênico dessas células (principais marcadores $\mathrm{CD}^{+} 9^{+}, \mathrm{CD} 0^{+}, \mathrm{CD}^{+} 4^{+}, \mathrm{CD} 31^{-}$; Tabela 1) é similar (30). Análises de expressão gênica demonstraram que menos do 1\% dos genes destas células são expressos diferencialmente (41), além de elas apresentarem potencial proliferativo semelhante. Somadas as características biológicas e de manipulação justificam a importância dos investimentos em estudos para o uso de ASC com fins terapêuticos. 
Introdução

Tabela 1: Marcadores Imunofenotípicos de Superfície de ASC versus BMMSC

\begin{tabular}{ccc}
\hline M. Superfície & ASC & BM-MSC \\
\hline CD9 & + & + \\
CD10 & + & + \\
CD11b & + & + \\
CD13 & + & + \\
CD29 & + & + \\
CD31 & - & - \\
CD34 & - & - \\
CD44 & + & + \\
CD54 & + & + \\
CD55 & + & + \\
CD71 & + & + \\
CD90 & + & + \\
CD91 & + & + \\
CD146 & + & + \\
CD166 & + & + \\
CD49d & - & + \\
CD106 & + & - \\
\hline
\end{tabular}

Abreviações: M. Superfície: marcadores de superfície; CD: cluster de diferenciação; ASC células-tronco mesenquimais derivadas do tecido adiposo; BM-MSC células-tronco mesenquimais derivadas da medula óssea, adaptado de Fraser et al. 2004.

\subsection{Banco de células-tronco - perfil imunológico e criopreservação}

As células-tronco mesenquimais também tem sido alvo de pesquisas no campo da imunologia. Diversos trabalhos têm demonstrado que estas células apresentam baixa imunogenicidade bem como propriedades imunomodulatórias, possivelmente relacionados com a ausência de expressão de MHC's de classe II e sua capacidade de inibir a proliferação de células T $(35,42-44)$. Estes dados têm sido demonstrados tanto em MSC (44-46) como em ASC (47-49).

Além disso, evidências sugerem que as células-tronco mesenquimais mantém suas características de auto-renovação e plasticidade mesmo após serem submetidas a longos períodos de congelamento (50-53). 
Introdução

As propriedades imunológicas somadas à manutenção de suas características após longo período de congelamento permitem extrapolações para o uso de células de fontes alogênicas (54), as quais podem ser mantidas criopreservadas. Esta é uma abordagem clinicamente interessante que torna possível a construção de bancos de células-tronco favorecendo tratamentos mais rápidos e custo-efetivos, além de garantir qualidade e controle fino das células que venham a ser utilizadas para transplante em pacientes.

\subsection{O Shear stress, células-tronco e o reparo cardíaco}

Um grande número de estudos tem demonstrado que células-tronco adultas, de diferentes fontes, podem se diferenciar em linhagens de células adipogênicas (23), osteogênica (23), condrogênica (55), miogênica (23), neurogênica (56), entre outras. Estas células também podem sofrer alterações no perfil de secreção de fatores de crescimento, citocinas, proteases, interleucinas $(14,15,27,57)$, o que pode ser modulado por diferentes estímulos químico/farmacológicos e/ou físicos.

Em cardiologia, o uso da terapia celular resultando em melhora funcional do coração aponta para mecanismos parácrinos capazes de alterar o microambiente das células atingidas pela lesão, bem como a formação de novos vasos através da angiogênese estimulada, por exemplo, pela liberação de óxido nítrico (NO) e fator de crescimento endotelial vascular (VEGF). Neste cenário, faz-se pertinente o desenvolvimento de estudos que explorem o potencial das células-tronco sob estímulos cardíacos. 
Introdução

Dentre os estímulos físicos sofridos por células presentes no coração, o Estresse de Cisalhamento - do inglês, shear stress (SS), causado pela força de tração do sangue paralelamente ao endotélio vascular, desperta grande atenção. Células endoteliais respondem a variações deste estímulo hemodinâmico com alterações morfológicas e funcionais do vaso sanguíneo.

Alterações na intensidade de SS que tornem o fluxo turbulento podem levar a formação de placas de aterosclerose (58), além disso, a expressão de diversas proteínas como a enzima conversora de angiotensina (ECA) (59, 60), fator de crescimento derivado de plaquetas (PDGF), endotelina-1, óxido nítrico sintetase endotelial (eNOS) (61), podem ser regulados pelo SS em células endoteliais.

Vista a importância do SS para sistema vascular e os resultados positivos obtidos até o momento em terapia de reparação cardíaca, estudos in vitro, com células-tronco, tem demonstrado que o SS sozinho ou em sinergismo com outros estímulos, é capaz de promover a expressão de proteínas como o receptor-2 de VEGF (FLK-1), caderina endotelial vascular (VE-caderina), CD31 e a alteração do perfil de secreção de fatores como o NO e o VEGF, característicos de células endoteliais $(27,62,63)$.

Baseado no desenvolvimento de estudos de aplicação de célulastronco, nos dados apresentados até o momento pela literatura e nos resultados obtidos por este laboratório, faz necessário o desenvolvimento de estudos em modelos animais de grande porte, como o suíno, que permitam extrapolações com seres humanos. Neste sentido, estudos de 
Introdução

caracterização, criopreservação e responsividade das ASC a estímulos químico/farmacológicos e físicos são de extrema importância. 
2. Objetivos 
Objetivos

\subsection{Objetivo geral}

Caracterizar uma população de células-tronco mesenquimais derivadas do tecido adiposo de porcos (pASC) antes e após serem submetidas a longo período de criopreservação e então testar a responsividade destas células ao shear stress.

\subsection{Objetivos específicos}

a) Padronizar a extração de pASC de porcos domésticos;

b) Gerar um banco de pASC;

c) Caracterizar as pASC criopreservadas e compará-las com pASC frescas;

d) Padronizar experimentos de indução de shear stress in vitro;

e) Avaliar as pASC submetidas ao shear stress, morfológica, imunofenotípica e funcionalmente. 
3. Materiais e Métodos 
Materiais e Métodos

\subsection{Isolamento, expansão e congelamento ex vivo de pASC}

Para a obtenção de células-tronco mesenquimais derivadas do tecido adiposo (pASC) foram utilizados 4 porcos domésticos $(20-30 \mathrm{~kg})$ Sus scrofa domesticus, (linhagem MS60 EMBRAPA). Os animais foram mantidos no biotério de manutenção do Instituto do Coração (InCor) a temperatura ambiente entre $22-28^{\circ} \mathrm{C}$, luz controlada em ciclo de 12 horas (claro-escuro) e com livre acesso à comida e água. Os procedimentos experimentais seguiram as normas institucionais para o cuidado e uso de animais de laboratório e foram aprovados pelo Comitê de Ética em Pesquisa da Faculdade de Medicina da Universidade de São Paulo, Brasil (Protocolo \#022/09).

Os animais foram pré-anestesiados com $3,5 \mathrm{~mL}$ de cloridrato de cetamina $(50 \mathrm{mg} / \mathrm{mL})$ e $1,5 \mathrm{~mL}$ de midazolam $(5 \mathrm{mg} / \mathrm{mL})$. A indução anestésica foi feita com $5 \mathrm{~mL}$ de tiopentato de sódio $(25 \mathrm{mg} / \mathrm{mL})$. Os animais foram intubados orotraquealmente e a anestesia foi mantida por via inalatória com isoflurano ( $1 \%$ de volume de ventilação) durante todo o procedimento.

A região abdominal do animal foi submetida à tricotomia e posterior assepsia/antissepsia. O animal foi coberto com campos cirúrgicos estéreis. Uma incisão na pele da região abdominal foi feita com lâmina de bisturi estéril. A gordura abdominal foi removida cirurgicamente, com auxílio de pinça e tesoura esterilizadas, e armazenada a $4^{\circ} \mathrm{C}$ em um frasco contendo solução de tampão fosfato salino (140 mM de $\mathrm{NaCl}, 2,7 \mathrm{mM}$ de $\mathrm{KCl}, 10 \mathrm{mM}$ 
Materiais e Métodos

de $\mathrm{Na}_{2} \mathrm{HPO}_{4}$ e $1,8 \mathrm{mM}$ de $\mathrm{KH}_{2} \mathrm{PO}_{4}$ - PBS) suplementado com 1\% penicilina G (100 U/mL)/estreptomicina $(100 \mu \mathrm{g} / \mathrm{mL})$ (P/S - Gibco, Invitrogen $\left.{ }^{\mathrm{TM}}\right)$.

As pASC foram isoladas do tecido adiposo como previamente descrito por Danoviz et al. 2010 (9). Em fluxo laminar o tecido adiposo foi submetido inicialmente à digestão mecânica, realizada com auxílio de pinça, tesoura e lâminas de bisturi. Em uma Placa de Petri fragmentos de tecido foram picotados até estarem completamente desestruturados formando uma massa de aspecto pastoso. Cada 10 gramas de tecido adiposo mecanicamente digeridos foram então submetidos à digestão enzimaticamente a $37^{\circ} \mathrm{C}$ por 45 minutos sob agitação em $20 \mathrm{~mL}$ de uma solução de colagenase tipo 1A a 0,075\% (C-2674; Sigma® ${ }^{\circledR}$; St. Louis, MO) suplementado com $1 \%$ albumina bovina sérica (BSA - Sigma®) em Dulbecco's Modified Eagle's Médium (Gibco, Invitrogen ${ }^{\mathrm{TM}}$ - DMEM). Após digestão enzimática do tecido, foi adicionada a solução $20 \mathrm{~mL}$ de soro fetal bovino (Gibco, Invitrogen ${ }^{\mathrm{TM}}$ - FBS) para inibição da ação da colagenase. A solução foi então centrifugada a $1500 \mathrm{rpm}$ por 10 minutos a $4^{\circ} \mathrm{C}$ e o pellet obtido ressuspendido em $10 \mathrm{~mL}$ de DMEM-low, suplementado com 10\% de FBS e $1 \% \mathrm{P} / \mathrm{S}$, este procedimento foi repetido até que toda a massa de gordura retirada dos animais fosse processada.

Cada $10 \mathrm{~mL}$ de suspensão de células-tronco foi plaqueado em uma placa de cultura de $10 \mathrm{~cm}$ (Greiner Bio-One). Após 2 horas de plaqueamento o meio de cultura foi retirado e meio limpo adicionado. As placas de cultura foram mantidas sob atmosfera úmida contendo $5 \%$ de $\mathrm{CO}_{2}$ a $37^{\circ} \mathrm{C}$ durante todo o período que estiveram em cultura. 
Materiais e Métodos

As células foram submetidas a repique sempre $80 \%$ de confluência foi observada. As pASC foram soltas da superfície das placas com solução de tripsina $(0.25 \%$ tripsina em $1 \mathrm{mM}$ EDTA - Vitrocell Co.) por cerca de 2 minutos, a $37^{\circ} \mathrm{C}$. A tripsina foi inativada usando FBS. Para avaliar a viabilidade de pASC, a cada repique estas células foram submetidas à contagem em Câmara de NeuBauer sob coloração com corante de viabilidade (Trypan Blue Vital Dye), onde as células mortas são evidenciadas pela cor azul. Elas foram então replaqueadas a uma densidade de $1 \times 10^{4}$ células $/ \mathrm{cm}^{2}$ ou em quantidades variáveis conforme necessário para cada experimento realizado.

As células pASC foram expandidas até a passagem 4 e então metade das células foram submetidas a congelamento. Para esse procedimento pASC foram descoladas das placas, contadas e então $3,3 \times 10^{6}$ pASC foram submetidas a congelamento em 10\% Dimetilsulfóxido (DMSO - 472301; Sigma-Aldrich Co.) e 90\% FBS em nitrogênio líquido (-196 C).

\subsection{Citometria de fluxo - marcadores de superfície de pASC}

A citometria de fluxo foi utilizada para caracterizar fenotipicamente as pASC. As células nas passagens 4 e 5 (pré e pós congelamento, respectivamente) foram coletadas das placas de cultura, utilizando-se solução de tripsina. As células foram centrifugadas a 1500rpm por 5 minutos a $4^{\circ} \mathrm{C}$ e o pellet obtido re-suspendido em $3 \mathrm{~mL}$ de meio de cultura. As células foram contadas em câmara de Neubauer e alíquotas contendo $0,5 \times 10^{6}$ células foram preparadas. Cada alíquota foi lavada com tampão de 
Materiais e Métodos

lavagem (PBS 1X; 2\% FBS; 0,02\% azida sódica) e centrifugada a 1500 RPM, por 5 minutos a $4^{\circ} \mathrm{C}$ por 3 vezes.

Após as lavagens as alíquotas foram incubadas a $4{ }^{\circ} \mathrm{C}$ por 30 minutos com anticorpos primários purificado (CD29, CD90, CD44 e CD31 - BD Biosciences, San Jose, CA). Foram submetidas então a mais 3 lavagens e foram incubadas com anticorpo secundário do tipo Alexa 488 (Invitrogen ${ }^{\mathrm{TM}}$ ) a $4{ }^{\circ} \mathrm{C}$ por 30 minutos. As alíquotas foram novamente lavadas 3 vezes e o pellet de células marcadas ressuspendidas em $500 \mu \mathrm{L}$ de tampão de lavagem e fixadas com 1\% de paraformaldeído (PFA).

Um total de 10.000 eventos foram adquiridos no citometro de fluxo FACSCalibur e o software Cell Quest (BD Biosciences San Jose, CA) foi utilizado para a análise dos dados obtidos.

\subsection{Elaboração das curvas de crescimento populacional das pASC}

Para avaliação das medidas de crescimento populacional, utilizou-se o protocolo descrito por Freshney RI (64). As pASC foram plaqueadas em oito placas de $35 \mathrm{~mm}$ na concentração de $5 \times 10^{4}$ células/poço. As células foram coletadas diariamente, placa a placa, por oito dias consecutivos. Para a coleta das pASC, utilizou-se $300 \mu \mathrm{L}$ de tripsina e posteriormente $400 \mu \mathrm{L}$ de PBS e as células, juntamente com a tripsina e o PBS, foram armazenadas em tubos com $300 \mu \mathrm{L}$ de formaldeído $37 \%$, totalizando $1 \mathrm{~mL}$ de solução em cada tubo. As células foram então contadas em câmara de Neubauer. Este teste foi realizado para as PASC em diferentes passagens e condições (frescas e descongeladas). As contagens foram realizadas por experimentador cego para o conteúdo dos tubos. 
Materiais e Métodos

O logaritmo (log) do número de células, em cada um dos dias durante os oito dias de cultivo das pASC, foi calculado e plotado num gráfico exponencial, a partir do qual foi obtida a curva de crescimento para as pASC. Nessa curva foram identificadas as fases lag, log e platô, que indicam a dinâmica das células durante os dias de cultivo e representam, respectivamente, as fases de adaptação, de crescimento exponencial (onde a taxa de proliferação é maior que a de morte celular) e de estabilização (quando a taxa de proliferação é igual à de morte devido à ausência de espaço físico para as divisões celulares - inibição por contato).

\subsection{Determinação do tempo de dobramento (TD) populacional - pASC}

A partir da curva de crescimento, identificou-se a fase de crescimento exponencial das células. Os pontos do gráfico que correspondiam a esta fase na curva de crescimento foram utilizados para a confecção de um segundo gráfico, cujo padrão se aproxima de uma reta ascendente.

Foi obtida, através do software Microsoft Excel@, a equação da reta (no formato $y=A x+B$ ) que melhor representasse a sequência desses pontos plotados no gráfico.

Foi realizado, então, o cálculo do TD, com base na seguinte fórmula:

$\left.A=\operatorname{LOG}_{10}(\mathrm{~N} 2)-\mathrm{LOG}_{10}(\mathrm{~N} 1)\right) / 0,301$, onde $A$ é coeficiente da equação da reta $y=A x+B$.

O coeficiente $A$ (da equação $y=A x+B$ ) determina a inclinação da reta, e representa a razão entre a variação do eixo das ordenadas e a variação do eixo das abscissas. Como no caso, a variação do eixo das ordenadas foi representada pela diferença entre o log de dois números 
Materiais e Métodos

quaisquer, de forma que um seja o dobro do outro - caracterizando o dobramento populacional, temos que a variação do eixo das abscissas nos fornecerá o tempo de dobramento (TD) populacional (em horas).

\subsection{Senescência}

Para quantificar o número de células senescentes ao longo das passagens 5 a 10 o método de coloração de SA- $\beta$-Gal em pH 6,0 foi realizado conforme descrito (65). Placas de $35 \mathrm{~mm}$ foram preparadas com $5 \times 10^{4} \mathrm{pASC} /$ poço vinte e quatro horas após o plaqueamento de pASC, estas foram retiradas da estufa de cultivo, o meio de cultura foi descartado e as placas lavadas com PBS 1X por 3 vezes. Então as células foram fixadas por 5 minutos em solução $2 \%$ formaldeído e $0,2 \%$ glutaraldeído. Após fixação, as pASC foram incubadas em uma solução de SA- $\beta$-Gal $(1 \mathrm{mg} / \mathrm{mL}$ X-Gal, 5 $\mathrm{mM}$ ferricianeto de potásio, $5 \mathrm{mM}$ ferrocianeto de potásio, $150 \mathrm{mM} \mathrm{NaCl}, 2$ $\mathrm{mM} \mathrm{MgCl} 2,40 \mathrm{mM}$ tampão ácido cítrico/fosfato em um pH 6.0) preparada logo antes da incubação, por 24 horas a $37^{\circ} \mathrm{C}$. Após as 24 horas de incubação oito campos aleatórios foram adquiridos através fotografias digitais, feitas em microscópio de contraste de fases (100X magnificação). Células positivas para coloração azulada (células senescentes) foram contadas por analisador cego para as passagens avaliadas. Para validação da coloração controles positivos foram preparados usando pASC em passagem 5 tratadas com 200 e $400 \mu \mathrm{M} \mathrm{H}_{2} \mathrm{O}_{2}$ por 2 horas a $37^{\circ} \mathrm{C}$, e cultivadas posteriormente por 8 dias em meio de cultura livre de $\mathrm{H}_{2} \mathrm{O}_{2}$. Após oito dias as células foram plaqueadas nas mesmas condições dos experimentos anteriores e a coloração com solução de SA- $\beta$-Gal realizada. 
Materiais e Métodos

\subsection{Diferenciação de pASC por indução química}

Para de demonstrar a plasticidade de pASC, estas foram estimuladas a diferenciarem-se em células das linhagens adipogênica e osteogênica. Placas de $35 \mathrm{~mm}$ 90-100\% confluentes foram mantidas em cultivo com meios de indução específicos para cada uma das linhagens. Os meios de indução foram preparados como descrito por Zuk, 2001 (40).

\subsubsection{Adipogênese}

A diferenciação adipogênica foi realizada num período de 4 semanas. As pASC foram mantidas em meio de diferenciação adipogênica em estufas sob atmosfera úmida contendo $5 \%$ de $\mathrm{CO}_{2}$ a $37^{\circ} \mathrm{C}$, as culturas foram acompanhadas diariamente por visualização em microscópio de fases e a troca de meio de diferenciação foi feita a cada 3 dias.

pASC foram induzidas com $2 \mathrm{~mL}$ de meio de cultura (DMEM-Low) suplementado com 10\% FBS, 0,5 mM de isobutil-metilxantina (IBMX), 1 mM de dexametasona, $10 \mathrm{mM}$ de insulina, $200 \mathrm{mM}$ de indometacina e $1 \%$ de P/S como descrito por Zuk (40). Durante o protocolo as placas de cultura foram fotografadas com câmera digital, aleatoriamente, para ilustrar o andamento do protocolo. Ao final das quatro semanas de indução, as culturas tanto de pASC induzidas a diferenciação como os controles negativos, mantidos em meio de cultura com 10\% FBS, foram submetidos ao método de coloração com Oil Red O (Sigma - ORO).

Ao final das quatro semanas de indução as placas de cultura foram retiradas das estufas, o meio de cultura descartado e as placas lavadas $2 \mathrm{X}$ com PBS 1X. Então as placas foram fixadas com formaldeído $10 \%$ por 30 
Materiais e Métodos

minutos a temperatura ambiente. Após fixação as placas foram lavadas $2 X$ com água destilada e incubadas com álcool isopropílico a 60\% por 5 minutos a temperatura ambiente. O álcool isopropílico foi removido e uma solução de ORO (60\% ORO em água deionizada) foi adicionada e mantida por 5-10 minutos a temperatura ambiente nas placas. O ORO foi então removido e as placas foram gentilmente lavadas com água corrente até que todo o excesso de ORO fosse eliminado. As placas foram fotografadas com câmera digital acoplada ao microscópio de fases (66).

\subsubsection{Osteogênese}

O protocolo de indução osteogênica também se deu no período de 4 semanas de tratamento das células. A troca de meio de diferenciação foi realizada a cada 3 dias e durante o protocolo as placas de cultura foram fotografadas em dias aleatórios para ilustrar o andamento do protocolo.

O meio de indução osteogênica foi preparado utilizando-se: meio de cultura (DMEM), 10\% FBS, 0,1 mM de dexametasona, $50 \mathrm{mM}$ de ácido ascórbico, $10 \mathrm{mM}$ de $\beta$-glicerofasfato e 1\% de P/S (40).

Ao final das quatro semanas de indução, as culturas tanto de pASC induzidas a diferenciação como os controles negativos, mantidos em meio de cultura com 10\% FBS, foram submetidos ao método de coloração com Alizarin Red S (Sigma - ARS) (67). As placas de cultura foram retiradas das estufas, o meio de cultura foi descartado e as placas lavadas $2 \mathrm{X}$ com PBS 1X. As placas foram então fixadas por 60 minutos a temperatura ambiente com etanol $70 \%$. Após fixação as placas foram lavadas 2 X com água destilada. Então as células foram incubadas por 30-45 minutos a 
Materiais e Métodos

temperatura ambiente em solução ARS (2\% ARS em água deionizada). 0 ARS foi removido e as placas foram lavadas com água corrente até que todo o excesso de ARS fosse eliminado. As placas foram fotografadas ao microscópio de fases para observação e registro, da matriz calcificada corada em vermelho.

\subsection{Experimentos com Shear stress - Diferenciação por Estímulo Físico}

Os experimentos de estimulação de células com shear stress foram realizados usando um sistema "cone-plate viscometer" (Figura 1) como descrito anteriormente $(59,68)$. pASC, após ciclo de congelamento/descongelamento, entre as passagens 5 e 7 , foram plaqueadas em placas de 10 e $15 \mathrm{~cm}$ nas densidades de $0,8 \times 10^{6}$ e $1,5 \times 10^{6}$ células respectivamente. Todos os experimentos foram realizados com os sistemas de "cone-plate viscometer" mantidos a $37^{\circ} \mathrm{C}$ em câmara úmida e $5 \%$ de $\mathrm{CO}_{2}$. 
A)
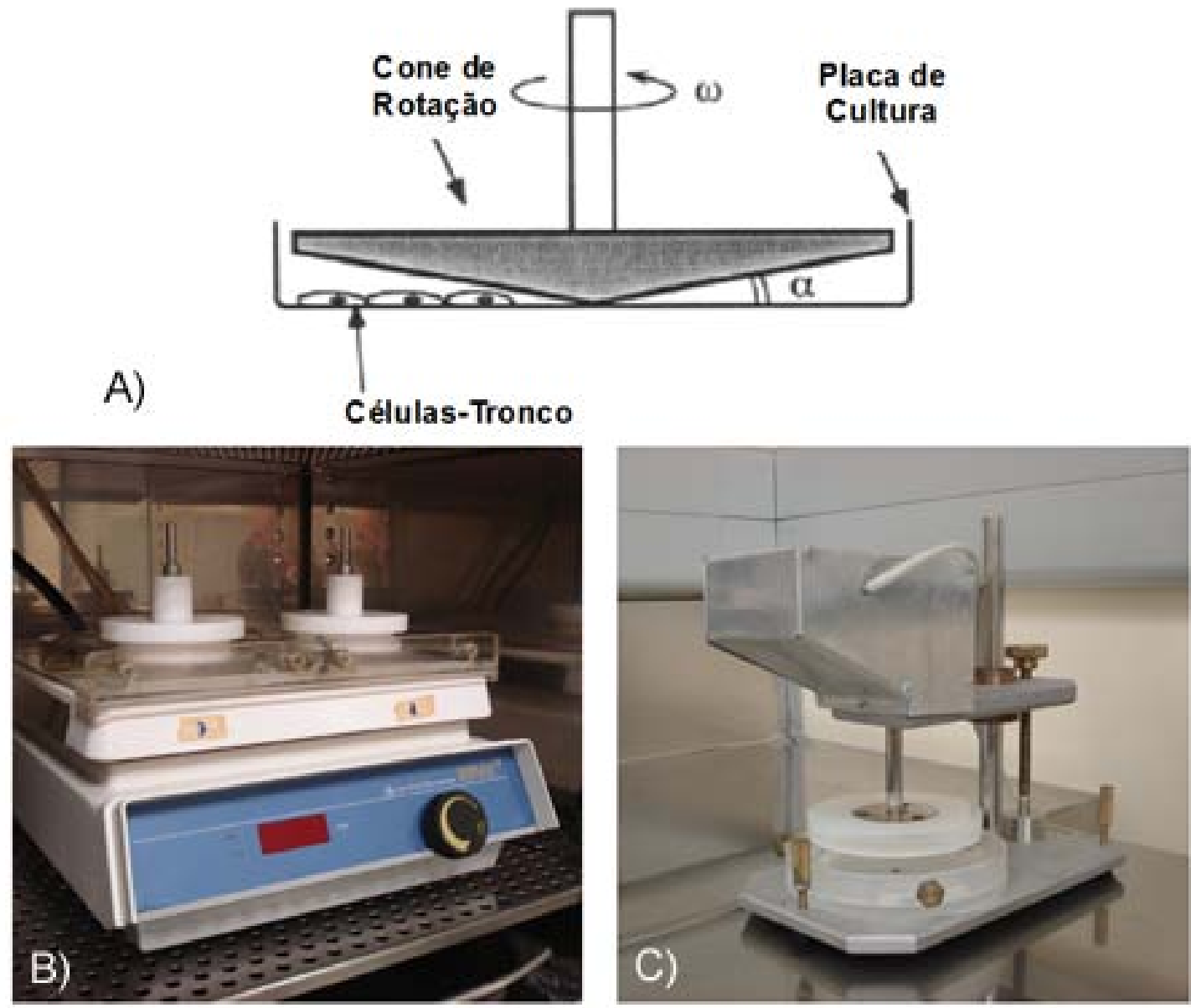

Figura 1: Sistema de "Cone-plate". A) Desenho esquemático de sistema de cone-plate. Adaptado de Malek et al. 1993. B) Foto ilustrativa de sistema de cone-plate para placas de $10 \mathrm{~cm}$. C) Foto ilustrativa de sistema de cone-plate para placas de $15 \mathrm{~cm}$.

Nos experimentos com as placas de $10 \mathrm{~cm}$, em um primeiro grupo de experimentos, 24 horas após plaqueamento, o meio de cultura sem suplementação com FBS foi adicionado e as células foram mantidas em "starving" (células mantidas em meio com menos FBS em período de adaptação) por 16 horas. Após esse período de starving o meio de cultura foi completamente trocado (por $10 \mathrm{~mL}$ de meio de cultura limpo e sem FBS) e as células estimuladas a 1-3, 5, 15 e $25-30 \mathrm{dyn} / \mathrm{cm}^{2}$ de shear stress por 30 minutos. Após 30 minutos, alíquotas de meio de cultura condicionado $(1 \mathrm{~mL})$ foram armazenadas e a proteína das células extraída. Em um segundo 
grupo de experimentos, 24 horas após plaqueamento, o meio de cultura das placas foi descartado e meio suplementado com 0,5\% FBS foi adicionado para realização de um período de 6-8 horas de starving. Após o starving, o meio de cultura foi novamente trocado por meio limpo (ainda suplementado com $0,5 \%$ de FBS) e então após 1 hora em estufa, as células foram submetidas a 5, 10 e $15 \mathrm{dyn} / \mathrm{cm}^{2}$ de SS por 48 horas. A cada 24 horas o sistema foi parado e uma alíquota de meio de cultura foi coletada $(1 \mathrm{~mL})$. $\mathrm{O}$ volume total de meio de cultura foi completamente trocado por meio limpo e o sistema ligado novamente. Os dados de 48 horas foram obtidos pela soma dos valores obtidos para as alíquotas de 24 e 48 horas. Células não submetidas ao SS foram usadas como controle estático em ambos os grupos de experimentos.

Nos experimentos em sistema de placas de $15 \mathrm{~cm}, 24$ horas após o plaqueamento, $40 \mathrm{~mL}$ de meio de cultura suplementado com 10\% FBS foi adicionado e após 1 hora em estufa as placas foram submetidas a 15 $\mathrm{dyn} / \mathrm{cm}^{2}$ de SS. Alíquotas de meio de cultura condicionado foram coletadas após 1, 24, 48, 72 e 96 horas ininterruptas de estimulação. Nestes experimentos quatro grupos de células foram avaliados. Em condição normal (meio 10\%FBS), suplementadas com inibidor do óxido nítrico sintase (1 mM L-NAME), em condição estática (meio 10\% FBS) e em condição estática e suplementadas com L-NAME (1 mM). 


\subsubsection{Determinação da produção de óxido nítrico (NO)}

O acúmulo de nitrito no meio de cultura foi aferido como medida indireta da produção de NO pelas células. Para a obtenção desta medida foi realizado o ensaio colorimétrico de Griess (69).

Alíquotas de meio de cultura condicionado de todos os experimentos de longa duração (24 e 48 horas) foram dosadas por essa técnica. $100 \mu \mathrm{L}$ do meio de cultura foram misturados a $100 \mu \mathrm{L}$ do reagente de Griess (50 $\mu \mathrm{L}$ de $1 \%$ de sulfonamida diluída em água deionizada e $50 \mu \mathrm{l}$ de $0,1 \%$ de N-(1NAFTIL) etilenodiamina dicloridrato diluído em 2,5 M de $\mathrm{H}_{3} \mathrm{PO}_{4}$ ). Após 10 minutos de incubação, à temperatura ambiente, para estabilizar a reação, foi feita a leitura de absorbância a 540 nm em espectrofotômetro. A concentração de nitrito no meio de cultura foi determinada por meio de uma curva-padrão preparada a partir de concentrações conhecidas de nitrito de sódio $\left(\mathrm{NaNO}_{2}\right)$.

Para os experimentos de curta duração de SS (30 minutos), nitrato e nitrito foram medidos um analisador do tipo Sievers NOA TM 280 nitric oxide analyzer, e os ensaios foram realizados conforme especificações do fabricante. Os dados obtidos foram demonstrados através da soma das leituras.

\subsubsection{Determinação de VEGF por ELISA}

Para realização da dosagem de VEGF no meio de cultura foi utilizado o método ELISA (do inglês, enzyme-linked immunoabsorbent assay) (R\&D System, Inc., Minneapolis, USA). Para esse ensaio foi utilizado um kit comercial de identificação para VEGF humano, que apresenta 
aproximadamente $90 \%$ de similaridade com o VEGF do porco, segundo o fabricante.

Uma placa com altíssima afinidade (MAXISORP NUNC) de 96 poços foi sensibilizadas com $100 \mu \mathrm{L}$ de anticorpo monoclonal anti-human VEGF e incubada por 18 horas à $4^{\circ} \mathrm{C}$. Posteriormente, a placa foi bloqueada para evitar ligações inespecíficas com $300 \mu \mathrm{L}$ de solução de bloqueio (BSA 2\%) e incubada por 2 horas à $37^{\circ} \mathrm{C}$. Após o bloqueio, foram adicionados $100 \mu \mathrm{L}$ por poço das amostras e dos padrões diluídos previamente em PBS. Em dois poços foram colocados somente PBS para caracterização do branco. A placa foi incubada por 18 horas à $4^{\circ} \mathrm{C}$. Após incubação, foram adicionados $100 \mu \mathrm{L}$ do anticorpo conjugado (Anticorpo anti-human Biotinilado) na concentração estabelecida e o material incubado por 3 horas à $37^{\circ} \mathrm{C}$. Posteriormente, foram adicionados $100 \mu \mathrm{L}$ de Estreptoavidina HRP (1:250) por poço e incubado por 30 minutos à $37^{\circ} \mathrm{C}$. A cada etapa a placa foi lavada com tampão de lavagem (PBS + Tween 20) por 6 vezes. A revelação foi realizada através da adição de $100 \mu \mathrm{L} /$ poço de solução de $\mathrm{H}_{2} \mathrm{O}_{2}$ e tetrametilbenzidina, incubando-se de 5 a 15 minutos a $37^{\circ} \mathrm{C}$. A reação foi interrompida com $50 \mu \mathrm{L}$ de $\mathrm{H}_{2} \mathrm{SO}_{4} 30 \%$ por poço sob agitação lenta.

A leitura das placas foi feita em leitor de ELISA (Power Wave, Bio-tek) utilizando filtro de $450 \mathrm{~nm}$. A concentração de VEGF no meio de cultura foi determinada por cálculos baseados em uma curva-padrão preparada a partir de VEGF de concentrações conhecidas fornecida no kit de ELISA. 
Materiais e Métodos

\subsubsection{Análise protéica - extração, eletroforese e western blotting}

Para analisar possíveis alterações de algumas proteínas após estimulação de pASC com SS, a proteína total de cada grupo experimental foi extraída. Após estímulos com SS as placas foram lavadas 2 X com PBS 1X gelado. Então foram adicionados $100 \mu \mathrm{L}$ de tampão de extração de proteínas (1\% TRITON X-100, 1 mM EGTA, 1 mM EDTA, 5 mM KCl, 2 mM MgCl2, 25 mM HEPES suplementado com 1:1000 fenil metil sulfonil fluoridro (PMSF) (Sigma), 1:300 coquetéis inibidores de fosfatases 1 e 2 (Sigma) e 1:300 inibidor total de proteases (Sigma)) e raspagem mecânica foi realizada. As proteínas extraídas foram armazenadas a $-80^{\circ} \mathrm{C}$ até o momento dos experimentos. A proteína total foi dosada utilizando Bradford Protein Assay (Biorad) com a metodologia proposta pelo fabricante.

Para realização da eletroforese, géis de SDS-PAGE de bis-acrilamida $6 \%$ foram feitos. $20 \mu \mathrm{g}$ de proteínas totais foram aplicadas nos géis para todos os experimentos realizados.

Após o término da corrida do gel de eletroforese, as proteínas foram transferidas para uma membrana de PVDF (GE Healthcare Life Sciences) em um sistema semi-seco (Trans-Blot SD Semi-Dry Electrophoretic Transfer Cell - Biorad) por 60 minutos. Após a transferência, a membrana foi corada com Ponceau S Stain (Invitrogen $®$ ), para confirmar a transferência das proteínas do gel para a membrana, e então permaneceu por 16-18 horas a $37^{\circ} \mathrm{C}$ para secagem. Quando seca a membrana foi submetida a bloqueio em tampão de bloqueio - PBS com 0,1\% de Tween 20 (PBST 0,1\%) e 5\% de BSA por 60 minutos. 
Materiais e Métodos

Ao final do bloqueio a membrana foi lavada 3 vezes com PBST 0,1\%, e finalmente incubada por $16-18$ horas a $37^{\circ} \mathrm{C}$ com anticorpo primário de interesse (FLK-1 1:300 \#07-716; Akt 1:1000 \#05-591; phospho-Akt 1:500 \#07-310 - Upstate-Millipore; Erk1/2 1:1000 - \#9102; phospo-Erk1/2 1:1000 \#9101 - Cell Signaling; $\beta$-actina 1:1000 ab8227 - ABCAM). Depois de seguidas lavagens, a membrana foi incubada por 1 hora com anticorpo antiIgG-HRP (1:3000, Invitrogen $®)$. Mais três lavagens com PBST 0,1\% foram realizadas e o Western Blotting foi revelado por método de quimiluminescência (ECL).

\subsubsection{PCR em Tempo Real}

A Reação em Cadeia da Polimerase (PCR) em tempo real foi utilizada para analisar a expressão gênica a partir da quantificação dos transcritos (RNAm) dos genes VEGF-A, CDH5 e $28 \mathrm{~S}$ das culturas de células submetidas a regime de shear stress e seus controle mantidos estáticos.

\subsubsection{Extração do ácido ribonucléico (RNA)}

Em cada grupo de estudo, as células foram lisadas das placas de cultura com TRIzol ${ }^{\circledR}(1 \mathrm{~mL}$ de TRIzol/100 mm do diâmetro das placas). O material insolúvel resultante da homogeneização foi retirado por centrifugação a 12.000 x G por 10 minutos a $4^{\circ} \mathrm{C}$. Essa solução foi coletada e transferida para um tubo de $1,5 \mathrm{~mL}$ e incubada durante cinco minutos à temperatura ambiente para permitir a completa dissociação dos complexos núcleo-protéicos. Então foi acrescentados $0,2 \mathrm{~mL}$ de clorofórmio, por $\mathrm{mL}$ de TRIzol utilizado, homogeneizado vigorosamente e incubado novamente, 
Materiais e Métodos

desta vez, por três minutos, à temperatura ambiente. Após essa segunda incubação, o material foi centrifugado a $12.000 \times \mathrm{G}$ por 15 minutos, a $4^{\circ} \mathrm{C}$.

Após a centrifugação do material, a fase aquosa foi descartada. O RNA foi precipitado com $0,5 \mathrm{~mL}$ de isopropanol (por $\mathrm{mL}$ de TRIzol utilizado inicialmente), por 10 minutos, à temperatura ambiente. Em seguida, o material foi novamente centrifugado a $12.000 \times \mathrm{G}$ por 10 minutos a $4^{\circ} \mathrm{C}$. $\mathrm{O}$ sedimento de RNA formado foi lavado com $1 \mathrm{~mL}$ de etanol $75 \%$ (por $\mathrm{mL}$ de TRIzol utilizado inicialmente) e centrifugado a $7.500 \times \mathrm{G}$ por cinco minutos a $4^{\circ} \mathrm{C}$. O sobrenadante foi removido e o pellet de RNA foi seco em temperatura ambiente por cinco minutos. O RNA total foi dissolvido em água destilada e livre de DNAse e RNAse (Gibco®), incubado por 10 minutos a $60^{\circ} \mathrm{C}$ (para a inativação de qualquer possível resíduo de RNase) e, finalmente, armazenado à $-80^{\circ} \mathrm{C}$.

\subsubsection{Verificação da integridade do RNA}

O RNA foi quantificado por espectrofotometria em $260 \mathrm{~nm}$, usando-se nanodrop ND-1000 (Thermo Scientific). Foi também determinada a razão entre 260 e $280 \mathrm{~nm}$, este dado nos forneceu uma estimativa da qualidade da extração.

A qualidade do RNA foi avaliada por eletroforese em gel de agarose 1\%. A eletroforese foi realizada na corrente constante de $70 \mathrm{~m} \AA$ por aproximadamente 45 minutos. Terminada a eletroforese, o gel foi corado com Brometo de Etídio (Invitrogen). As amostras que se mostraram íntegras foram utilizadas como substrato para a transcrição reversa. 
Materiais e Métodos

\subsubsection{Transcrição reversa do RNA (RT)}

A transcrição reversa é um processo que converte as moléculas do RNA em ácido desoxirribonucleico complementar (cDNA). A transcrição reversa do RNA total obtido das células foi realizada utilizando o kit de síntese de cDNA SuperScript II (Invitrogen) segundo manual do fabricante.

A amostras contendo $1 \mu \mathrm{g}$ de RNA total foi adicionado $1 \mu \mathrm{L}$ de OligodT (0,5 $\mu \mathrm{g} / \mu \mathrm{L}), 1 \mu \mathrm{L}$ de dNTP's (10 mM) e um volume de $\mathrm{H}_{2} \mathrm{O}$ DEPC totalizando de $12 \mu \mathrm{L}$ de volume final. Esta solução foi incubada por 5 minutos a $65^{\circ} \mathrm{C}$. Em seguida, as amostras foram incubadas por 1 minuto a $4{ }^{\circ} \mathrm{C}$ e então foi adicionado $4 \mu \mathrm{L}$ de tampão de transcriptase reversa (MMLV reverse transcriptase $5 \mathrm{X}$ buffer), $2 \mu \mathrm{L}$ DTT (0,1 M) e $1 \mu \mathrm{L}$ RNaseOut (40 U/ul) (inibidor de RNAses), seguido de incubação, por 2 minutos a $42{ }^{\circ} \mathrm{C}$. Então $1 \mu \mathrm{L}$ de enzima de transcriptase reversa $(200 \mathrm{U} / \mu \mathrm{L})$ foi adicionado à mistura e cada amostra foi incubada por 50 minutos a $42{ }^{\circ} \mathrm{C}$, seguido por um período de 15 minutos a $70{ }^{\circ} \mathrm{C}$. Ao final do protocolo de síntese de cDNA todas as amostras foram armazenadas $\mathrm{a}-20^{\circ} \mathrm{C}$

\subsubsection{Reação em cadeia da polimerase (PCR) - qRT-PCR}

As reações de qRT-PCR foram realizadas em um sistema ABI Prism 7700 Sequence Detection System (Applied Biosystems) utilizando o kit SYBRw Green PCR Master Mix-PE (Applied Biosystems). Todas as amostras foram dosadas em duplicatas. O gene ribossomal $28 \mathrm{~S}$ foi utilizado como gene controle, para normalização dos dados obtidos para os genes de interesse (VEGF e VE-caderina). 
Materiais e Métodos

O volume reacional de $20 \mu$ l contendo $1 \mu \mathrm{l}$ de cDNA foi utilizado, sendo a concentração deste cDNA previamente definida através de uma curva de diluição, a qual, foi feitas a partir da amplificação de diluições seriadas de um cDNA proveniente de uma placa de cultura de células em condição estática e outra em condição de Shear stress. Cada amostra foi colocada em um mix para a realização da PCR contendo: $200 \mathrm{nM}$ de cada primer, $10 \mu \mathrm{l}$ de $2 \mathrm{X}$ SYBR Green PCR Master Mix (Applied Biosystems) composta de AmpliTaq DNA Polymerase, SYBR Green buffer, SYBR Green I, dNTP's e de uma referência passiva chamada ROX que também é um corante fluorescente e 7,96 $\mu \mathrm{L}$ de água DEPC (livre de RNases). A mix foi então submetida a $95^{\circ} \mathrm{C}$ por 10 minutos para a ativação da Taq DNA Polymerase, seguido de $95^{\circ} \mathrm{C}$ por 15 segundos repetidamente por 50 ciclos e então a $60^{\circ} \mathrm{C}$ por 60 segundos como período de extensão onde a coleta do sinal de fluorescência foi realizada.

O método análise por número de ciclos necessários para que o produto de PCR atinja o limiar fixado (threshold) de detecção (CT) foi utilizado, onde CT indica o número fracionário de ciclos em que a quantidade do gene alvo amplificada chega a um limiar fixado, e $\Delta C T$, a diferença entre limiar fixado para o gene alvo (VEGF e VE-caderina) e para o gene de referência (28S). Os níveis de expressão gênica de VEGF e VE-caderina foram expressos por $2^{-\Delta \Delta C T}$; onde $\Delta \Delta C T$ é o valor de $\Delta C T$ das células induzidas por SS subtraído do valor de $\Delta \mathrm{CT}$ das células estáticas.

Os primers para VEGF, VE-caderina e $28 \mathrm{~S}$ (Tabela 1) foram sintetizados comercialmente. Eles foram desenhados no Software Primer3 
Materiais e Métodos

(http://www.broad.mit.edu/cgi-bin/primer/primer3_www.cgi), a partir das seqüências de cDNA desses genes disponíveis no GenBank (http://www.ncbi.nlm.nih.gov/Genbank). Os primers foram confeccionados como 18-22 nucleotídeos, com cerca de 50\% G/C, temperatura de anelamento entre $58-60^{\circ} \mathrm{C}$, além disso, não apresentarem mais de $2 \mathrm{Gs}$ ou Cs na extremidade 3', sendo o tamanho do produto da amplificação não inferior a 50 e nem superior a $150 \mathrm{bp}$. O primer Sense e Antisense foram desenhados em éxons diferentes para evitar problemas com possíveis contaminantes de DNA genômico.

Tabela 2: Primers usados para RT-PCR e qRT-PCR

Amplicon

\begin{tabular}{cccc} 
Gene & $\mathbf{( p b )}$ & Primer Forward (5'-3') & Primer Reverse (5'-3') \\
\hline VEGF & 190 & TTGCTGCTCTACCTCCACC & CACAGGACGGCTTGAAGAT \\
VE-cade & 93 & GGTCACTCGCTCATGCTCT & GCCAGAGTTGATGTGGGTC \\
$28 S$ & 102 & TCATCAGACCCCAGAAAAGG & GATTCGGCAGGTGAGTTGTT \\
\hline
\end{tabular}

Abreviação: pb: pares de base.

Depois de construídos, os primers foram submetidos a uma análise pelo programa BLAST disponível no site http://www.ncbi.nlm.nih.gov/BLAST, para verificar a especificidade dos oligos gerados. 
Materiais e Métodos

\subsection{Estatística}

Os resultados foram expressos por média \pm erro padrão da média (EPM). Análises de variância de uma ou duas vias (ANOVA) com testes post-hoc do tipo Bonferroni, ou testes $\mathrm{t}$ de Student não pareados foram utilizados para comparar grupos e tratamentos quando apropriado. Todas as análises estatísticas foram feitas usando o Software GraphPad Prism 5.0 (GraphPad Softwares Inc.,CA, USA). Valores de $\mathrm{p}<0.05$ foram considerados significativos. 
4. Resultados 
Resultados

\subsection{Caracterização das células mesenquimais de tecido adiposo de porcos (PASC) - gerando um banco de células}

As pASC foram obtidas de um único animal com o objetivo de gerar um banco de células para futuro uso em terapia celular. Esta população de pASC foi submetida a caracterização e então foi comparada à pASCs de outros três animais, em condições normais de cultivo após a extração (denominadas aqui células frescas) e após um ciclo de congelamento/descongelamento (denominadas aqui de células descongeladas). Os protocolos de caracterização foram realizados da passagem 5 até a passagem 10.

\subsection{Isolamento, expansão e congelamento ex vivo de pASC}

A eficiência da extração mecânica e posteriormente enzimática foi, em média, 7 milhões de células em passagem 0 a cada 10 gramas de tecido adiposo após 4 dias de cultivo. Após as primeiras horas de plaqueamento, as pASC ainda não se encontravam completamente aderidas e havia um grande número de contaminantes como hemácias, adipócitos e restos de células mortas pelos processos de extração. Para ampliar o número de células aderidas e favorecer que as células restantes conseguissem aderir, após duas horas do plaqueamento, todo o meio de cultura plaqueado foi transferido para uma nova placa, este procedimento aumentou consideravelmente o número final de células obtidas a cada extração.

As pASC demonstraram alta capacidade de expansão in vitro exibindo uma morfologia similar a de um fibroblasto (aspecto fusiforme - fibroblastlike), durante todo o período observado (Figura 2). As culturas se tornaram 
Resultados

morfologicamente mais homogêneas à medida que as células sofreram o repique mudando de passagem e sendo expandidas para novas placas.

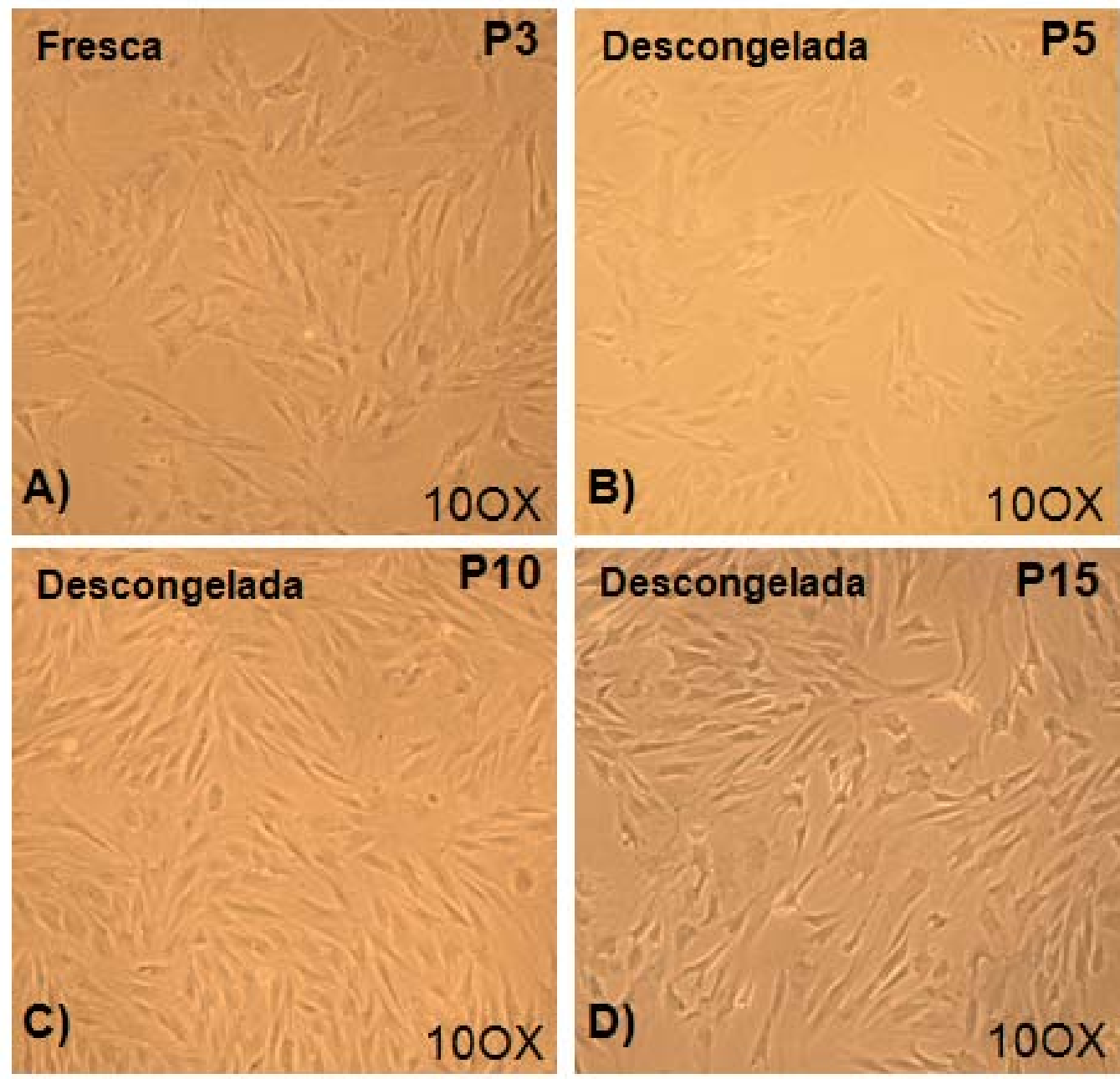

Figura 2: Morfologia de pASC Antes e Após Congelamento. A) pASC em passagem 3, antes de ser submetida a ciclo de congelamento/descongelamento. B) pASC em passagem 5, 48 horas após descongelamento. C) pASC em passagem 10. D) pASC em passagem 15. Notar a similaridade morfológica (Fibroblast-like) das pASC acima representadas, independentemente da passagem e condição (frescas/descongeladas). Todas as imagens com magnificação de 100X.

As células obtidas foram então expandidas em cultura até passagem 4 onde cerca de 3 bilhões de células de um único animal (300 gramas de tecido adiposo) foram congeladas em tubos de criopreservação $\left(3,3 \times 10^{6}\right.$ células/tubo) e armazenadas em nitrogênio liquido para futuros estudos de caracterização e uso em terapia celular. Os mesmo procedimentos foram 
Resultados

realizados para outros três animais, porém em menor escala (30 gramas de tecido adiposo em média). Paralelamente ao congelamento das pASC, uma parcela das células foi mantida em cultura não sendo submetida a congelamento, para que estudos comparativos pudessem ser realizados.

\subsection{Viabilidade das pASC após descongelamento e entre passagens}

Com o objetivo de avaliar a viabilidade de pASC a cada repique, estas células foram submetidas à contagem em Câmara de Neubauer com Trypan Blue Vital Dye, desde a passagem 5 até a passagem 10, tanto nas culturas submetidas ao congelamento como nas frescas, para posterior comparação. Cerca de $90-95 \%$ de células viáveis entre as passagens 5 e 10 foram obtidas independentemente da condição das células (descongeladas P5 vs. descongeladas 6-10, 90,58\% $\pm 1,52$ vs. 95,40\% $\pm 0,26$ ) (Figura 3). Entretanto, a viabilidade das células-tronco frescas manteve-se alta e estável em todas as passagens avaliadas (P5 a P10, 96,18\% $\pm 0,27$ em média) (Figura 3) sugerindo que o aumento de mortalidade observado em pASC descongeladas em P5 ocorre devido ao processo de congelamento, mas não altera a população durante o restante do período avaliado. 


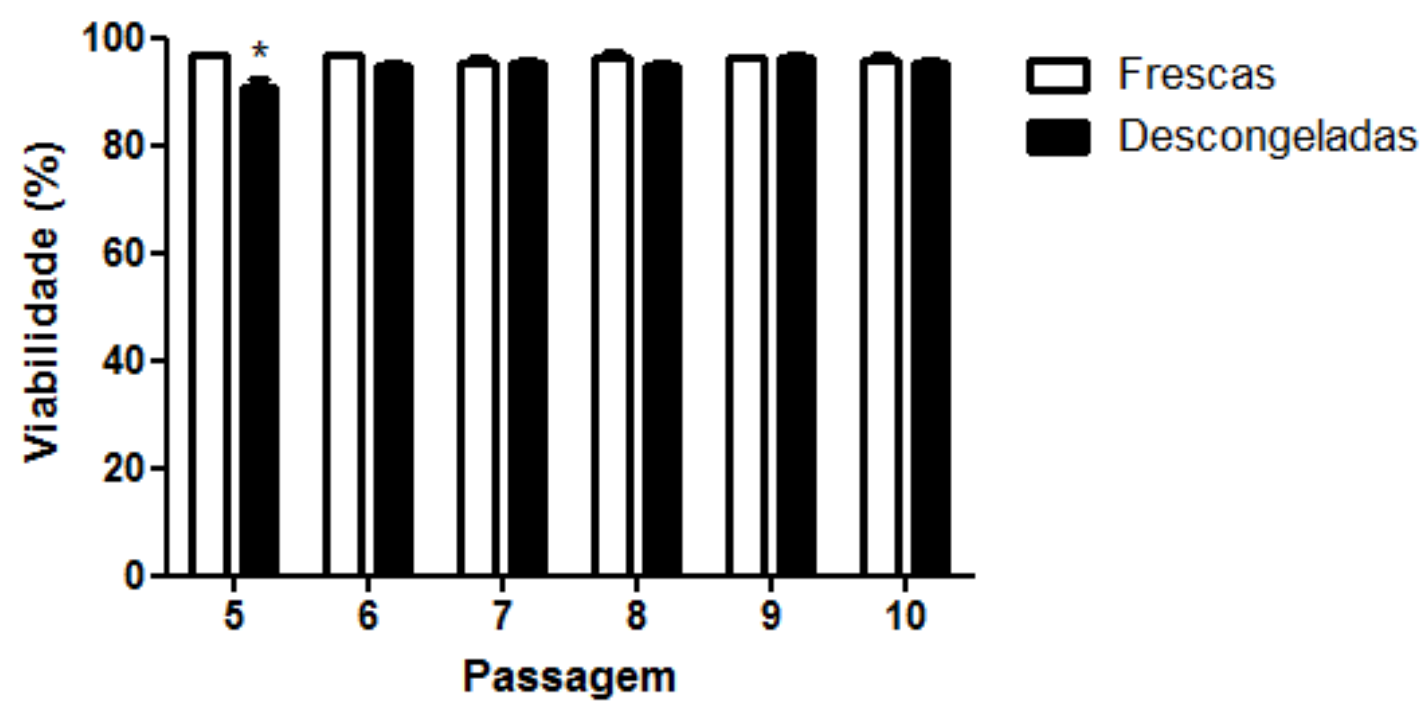

Figura 3: Viabilidade após descongelamento e entre passagens de pASC. Observa-se que após o descongelamento as pASC, em passagem 5, demonstraram uma redução estatisticamente significativa em sua viabilidade comparado as células frescas $\left({ }^{*} P<0.001 ; n\right.$ frescas $=3$ animais $/$ passagem e $n$ descongeladas $=4$ animais $/$ passagem) .

\subsection{Marcadores de superfície - imunofenótipo mesenquimal}

Os marcadores de superfície CD29, CD90 e CD44 e também o marcador de células endoteliais CD31 foram analisados por citometria de fluxo em culturas de pASC nas passagens 4 e 5 tanto antes e após o congelamento, respectivamente. A homogeneidade da população pode ser observada no gráfico de tamanho em função da granulosidade das células (Figura 4). 
Resultados

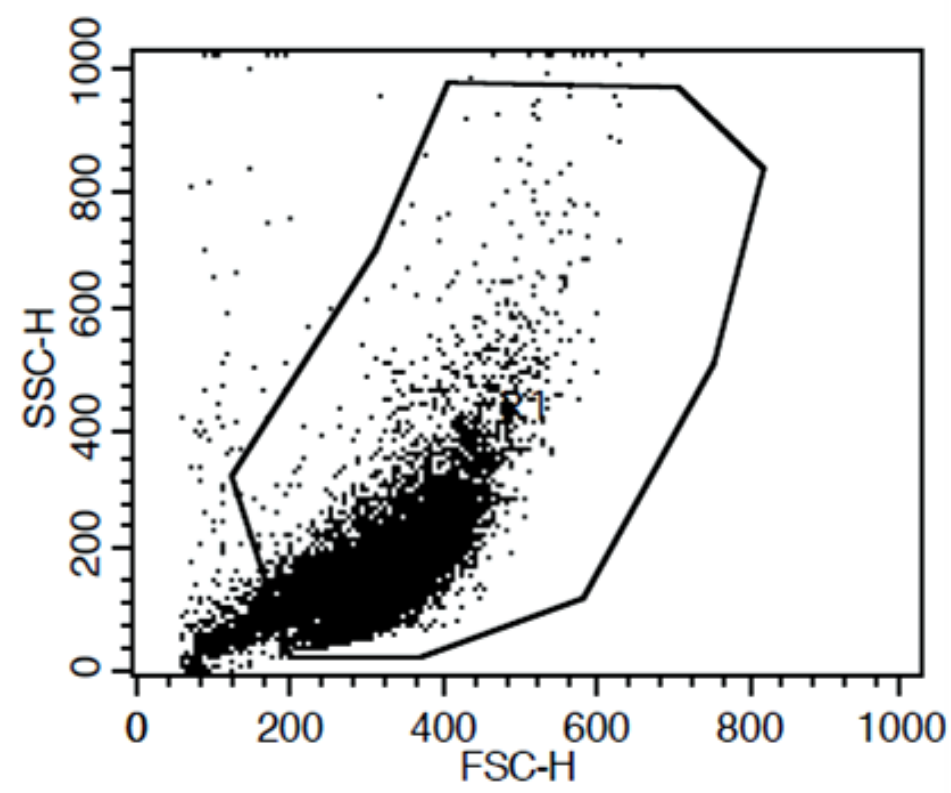

Figura 4: Homogeneidade da população de pASC. Gráfico de tamanho (FSC) em função da granulosidade (SSC) de pASC. A área delimitada pelo polígono (denominado "gate") acima representado demarca os eventos (células) com perfil considerado positivo para análises posteriores em citometria de fluxo. A elevada concentração de eventos visualizados nesse gate demonstra a homogeneidade da população de pASC avaliada.

Os valores obtidos para cada passagem foram transformados em valor médio para cada animal analisado, já que não houve diferença significativa entre as passagens (Tabela 2). Então os valores médios de cada animal (3 animais) foram plotados em um gráfico de barras que expressa a média das células positivas para cada marcador. O perfil dos marcadores pode ser visualizado na figura 5. 
Resultados
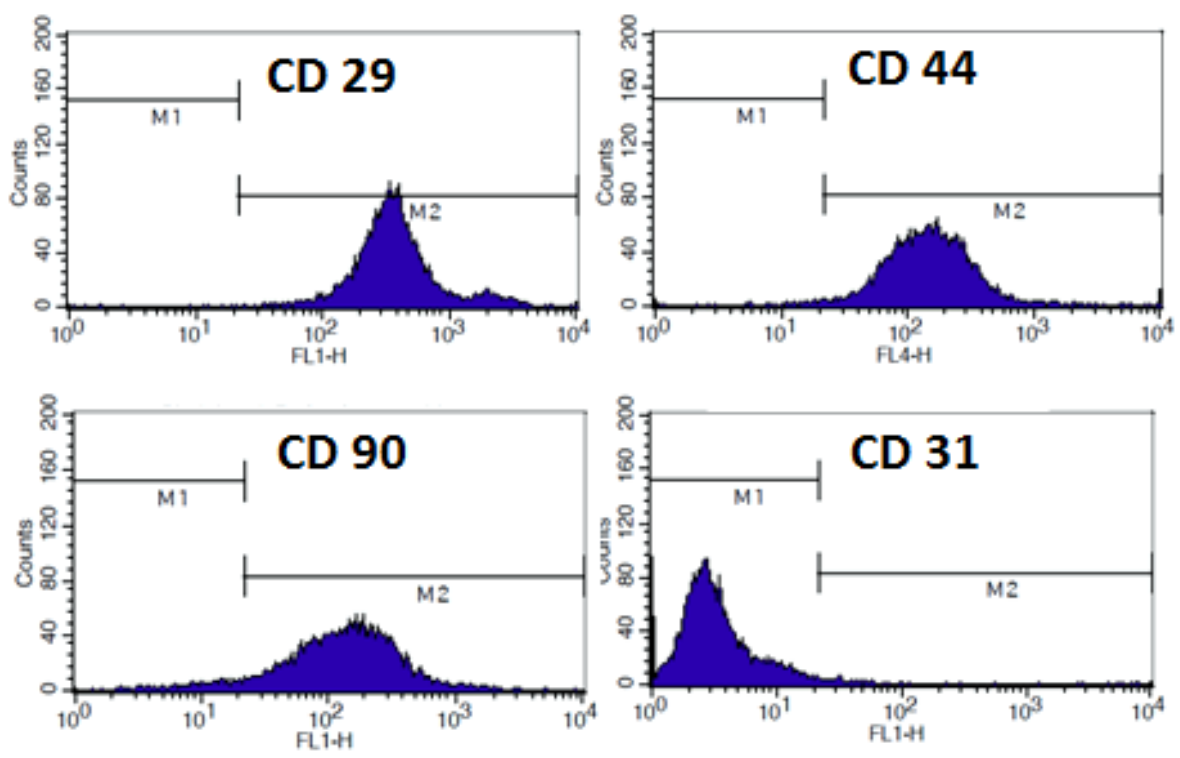

Figura 5: Histograma representativo para marcadores avaliados por citometria de fluxo. Os eventos avaliados são representados pelas barras azuis. O número de eventos observados está representado no eixo $y$, enquanto que as intensidades de fluorescência obtidas para cada evento se encontram no eixo x. M1/M2 representam os limites estabelecidos para definir se um evento é positivo ou negativo para o marcador avaliado.

Tabela 3: Caracterização imunofenotípica de pASC em passagens 4 e 5, antes ou após serem submetidas a congelamento.

\begin{tabular}{|c|c|c|c|c|c|c|c|c|c|c|c|}
\hline \multirow[b]{3}{*}{ Marcador } & \multicolumn{6}{|c|}{ Animal } & \multirow[b]{3}{*}{ Média } & \multirow[b]{3}{*}{ \pm} & \multirow[b]{3}{*}{$\begin{array}{c}\text { Erro } \\
\text { Padrão }\end{array}$} & \multirow[b]{3}{*}{ Resultado } & \multirow[b]{3}{*}{ Esperado } \\
\hline & \multicolumn{2}{|c|}{1} & \multicolumn{2}{|c|}{2} & \multicolumn{2}{|c|}{3} & & & & & \\
\hline & $\mathbf{F}$ & D & $\mathbf{F}$ & D & $\mathbf{F}$ & D & & & & & \\
\hline CD29 & 95,75 & 99,84 & 98,87 & 99,54 & 99,80 & 99,85 & 98,94 & \pm & 0,66 & + & + \\
\hline CD90 & 97,02 & 95,19 & 99,49 & 99,12 & 99,12 & 99,22 & 98,19 & \pm & 0,64 & + & + \\
\hline CD44 & 99,50 & 99,03 & 99,58 & 99,71 & 99,39 & 99,44 & 99,44 & \pm & 0,09 & + & + \\
\hline CD31 & 1,81 & 1,33 & 2,25 & 2,04 & 2,33 & 1,90 & 1,94 & \pm & 0,15 & - & - \\
\hline
\end{tabular}

Abreviações: $F=$ células frescas; $D=$ células descongeladas; 1,2 e 3 = animais avaliados.

A análise resultou num perfil fenotípico para a população de pASC na qual essas células foram caracterizadas como: $\operatorname{CD}^{+} 9^{+}(99,74 \% \pm 0,10 ; n=3)$, $\mathrm{CD}^{+}(97,84 \% \pm 1.32 ; \mathrm{n}=3), \quad \mathrm{CD}^{+} 4^{+}(99,39 \% \pm 0.19 ; \quad \mathrm{n}=3)$ e $\mathrm{CD}^{-}$ $(1,75 \% \pm 0.21 ; n=3)$ (Figura 6). 
Resultados

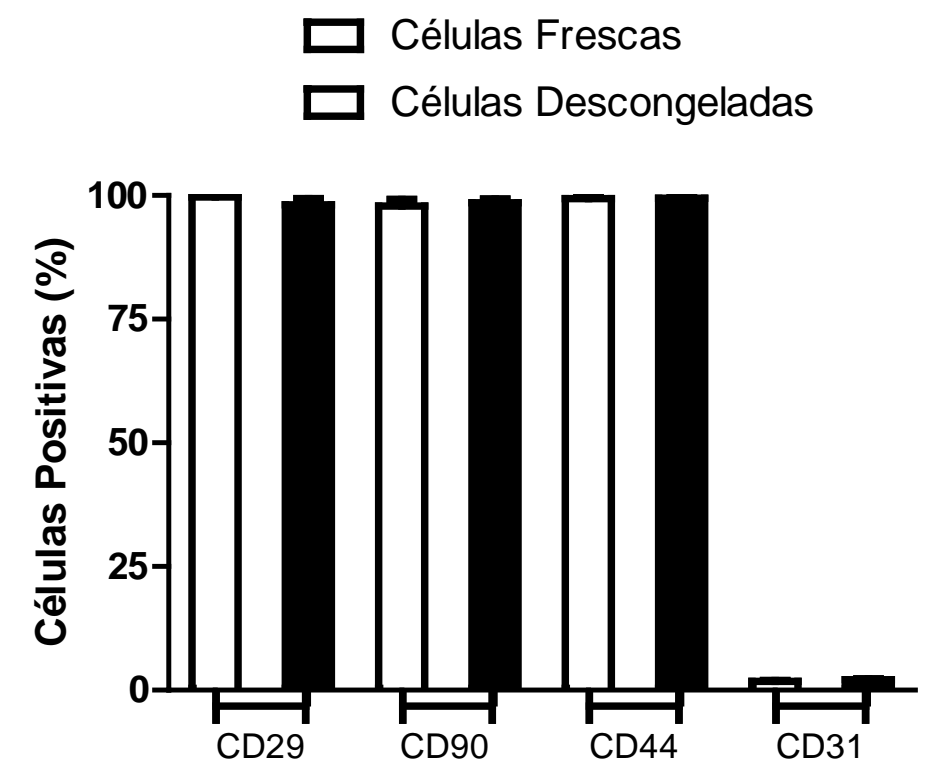

Figura 6: Marcadores Mesenquimais de Superfície das pASC. Note que não há diferenças estatisticamente significativas entre os marcadores de superfície avaliados para células frescas VS. Células descongeladas ( $n=3$ animais por marcador em cada condição). $O$ marcador CD 31 foi avaliado como controle negativo para células-tronco mesenquimais e os resultados obtidos confirmaram a homogeneidade da população nas passagens avaliadas.

\subsection{Cinética de crescimento das pASC}

A capacidade proliferativa das PASC foi avaliada através de curvas de crescimento celular das quais foi possível exprimir o tempo de dobramento médio das pASC. Além disso, através do acompanhamento das pASC em cultura durante o período avaliado o índice de dobramento populacional foi calculado.

\subsubsection{Tempo de dobramento}

A taxa de proliferação das pASC foi avaliada passagem a passagem de P5 até P10 (células em fase proliferativa) através das curvas de crescimento celular. Conforme pode ser observado no gráfico da figura 7 
Resultados

não há diferenças estatisticamente significativas no tempo de dobramento entre as passagens avaliadas.

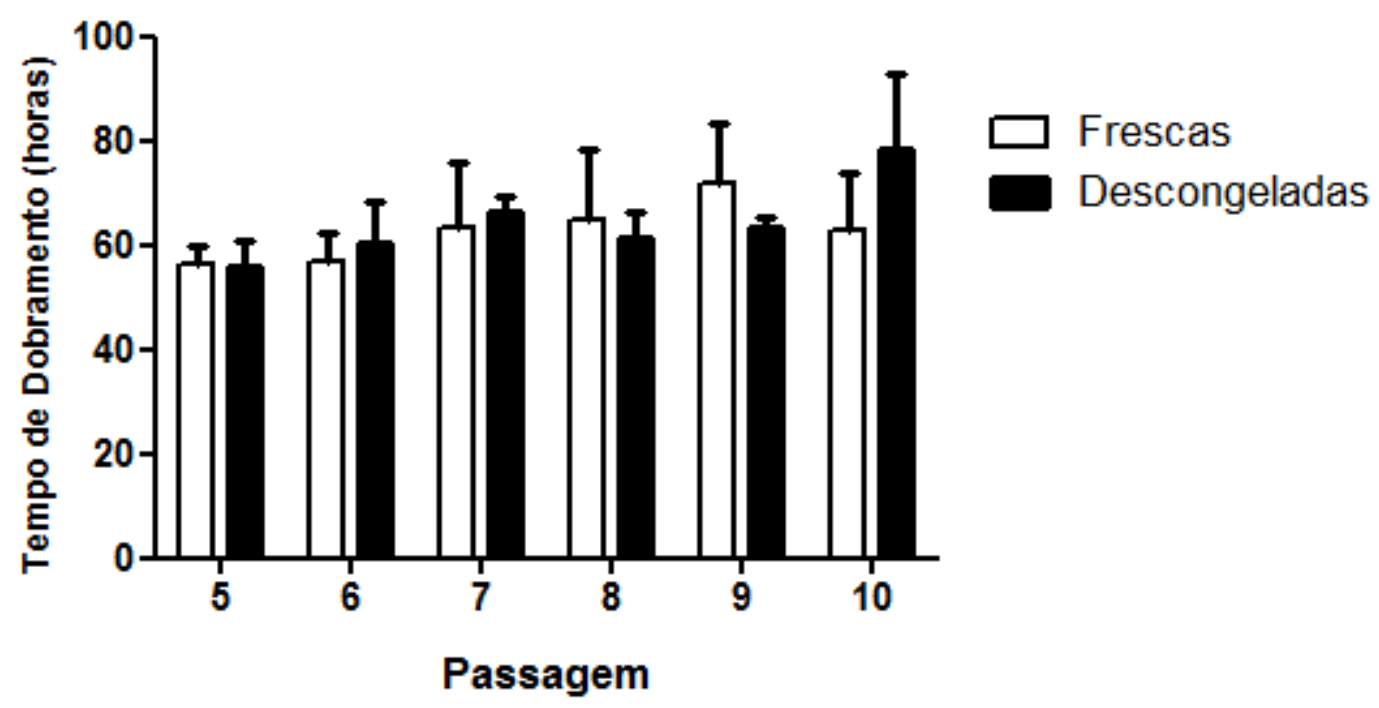

Figura 7: Tempo de dobramento das pASC. Tempo de dobramento de pASC da passagem 5 a 10. Não há diferenças estatisticamente significativas do tempo de dobramento de pASC independentemente da passagem e condição avaliada $(p>0,05) \quad n=4$ por passagem/condição.

O tempo de dobramento médio das pASC descongeladas obtido na análise das passagens 5 a 10 foi de 64,26 horas $\pm 15,11$. Para as células frescas o tempo de dobramento médio foi de 62,74 horas $\pm 18,07$, não havendo diferenças estatísticas significativas entre as condições de congelamento e não congelamento. Deste modo o tempo de dobramento médio das pASC independentemente da condição avaliada foi calculado resultando em 63,51 horas $\pm 16,46$.

\subsection{2. Índice de dobramento populacional cumulativo (IDPC)}

Através das quantidades de células iniciais e finais ao final de cada processo de repique entre as passagens 5 e 10 de pASC em cultura, foi 
Resultados

possível avaliar o índice de dobramento populacional cumulativo em função do tempo para cada animal estudado (Figura 8).

\section{5-10 Passagens}

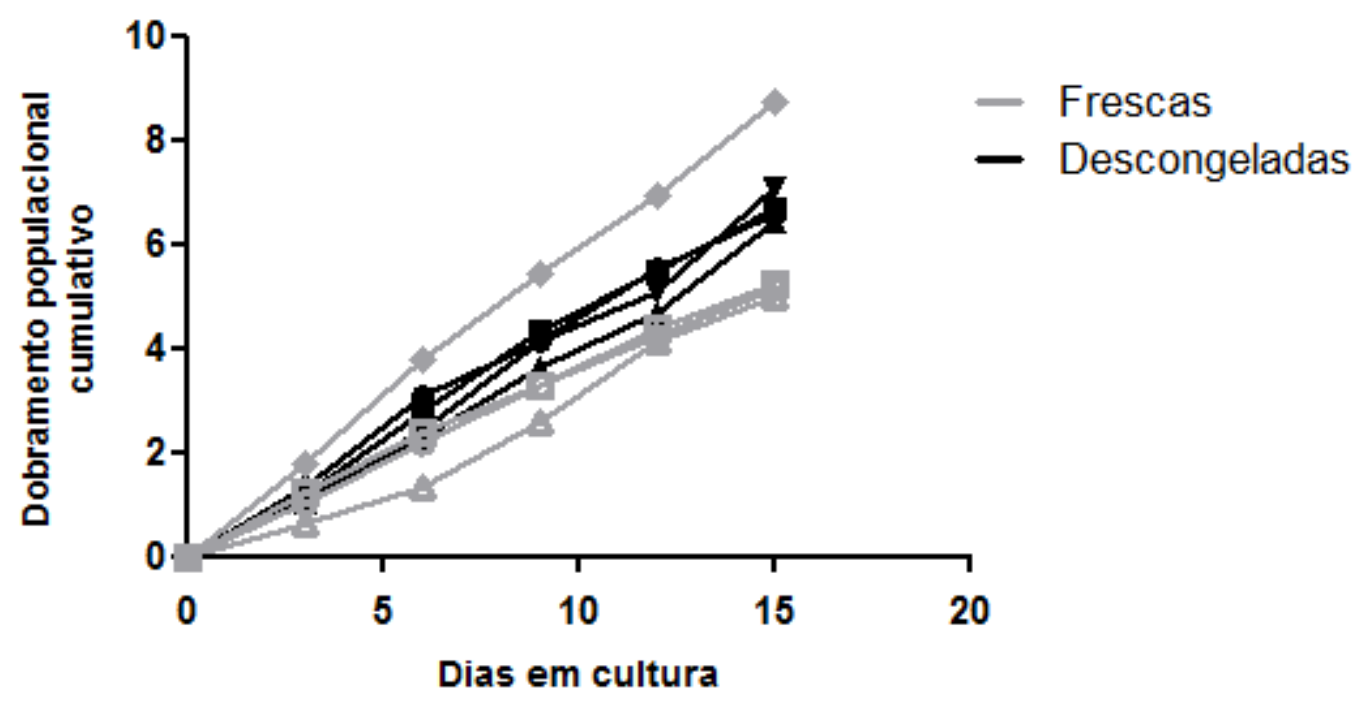

Figura 8: Índice de Dobramento Populacional Cumulativo (IDPC) de pASC em função do tempo em dias de cultura. O gráfico acima demonstra individualmente o IDPC de pASC de cada animal mantido e acompanhado em cultura ao longo do período de avaliação. Note que não há decréscimo no potencial proliferativo de nenhuma das pASC avaliadas (n células frescas $=4$ e $n$ células descongeladas $=3$ ).

Para permitir melhor compreensão deste dado o IDPC médio das pASC congeladas e frescas foi calculado, sendo o IDPC médio das pASC submetidas a ciclo de congelamento/descongelamento igual a 1,27 dobramentos populacionais por passagem, no período avaliado. O IDPC médio das pASC frescas foi de 1,20 dobramento populacionais por passagem no mesmo período, não havendo diferença estatisticamente significativa entre células congeladas e células frescas $(p>0,05)$ (Figura 9) permitindo o cálculo de um IDPC médio para pASC independentemente da condição avaliada, da ordem de 1,24 dobramentos populacionais por passagem avaliada. 
Resultados

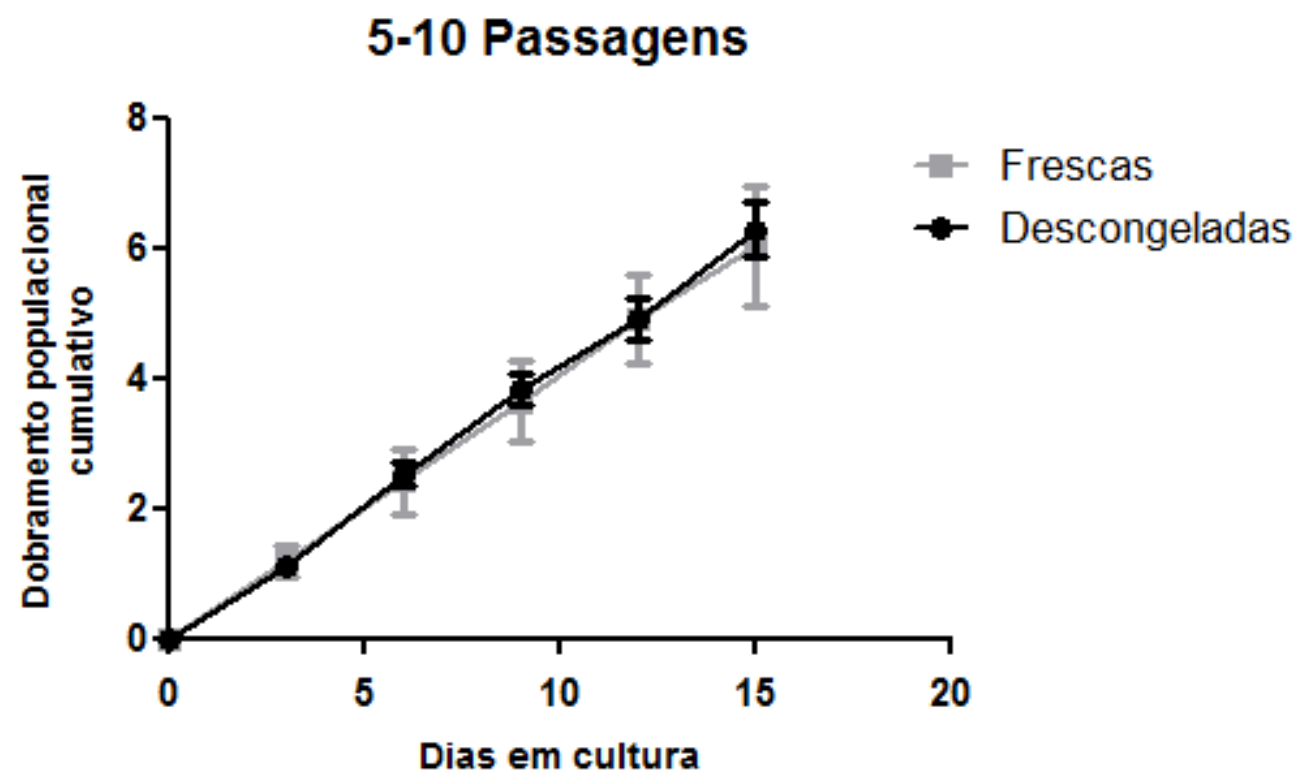

Figura 9: Índice de Dobramento Populacional Cumulativo (IDPC) médio de pASC em função do tempo em dias de cultura. O gráfico acima demonstra o IDPC médio das pASC descongeladas VS. pASC frescas. Note que não há decréscimo no potencial proliferativo das pASC avaliadas independentemente da condição ( $\mathrm{n}$ células frescas $=4$ e $n$ células descongeladas $=3$ ).

É possível observar uma relação estritamente linear dos dados de dobramento populacional cumulativo e número de passagem para pASC em ambas condições avaliadas indicando uma taxa de dobramentos populacionais relativamente constante, que pode ser observada no gráfico da figura 10. Ademais, nenhuma redução significante de dobramentos populacionais cumulativos foi observada nas passagens durante o período de análise, o que sugere que o congelamento de pASC não altera o potencial proliferativo destas células entre as passagens 5 e 10 . 
Resultados

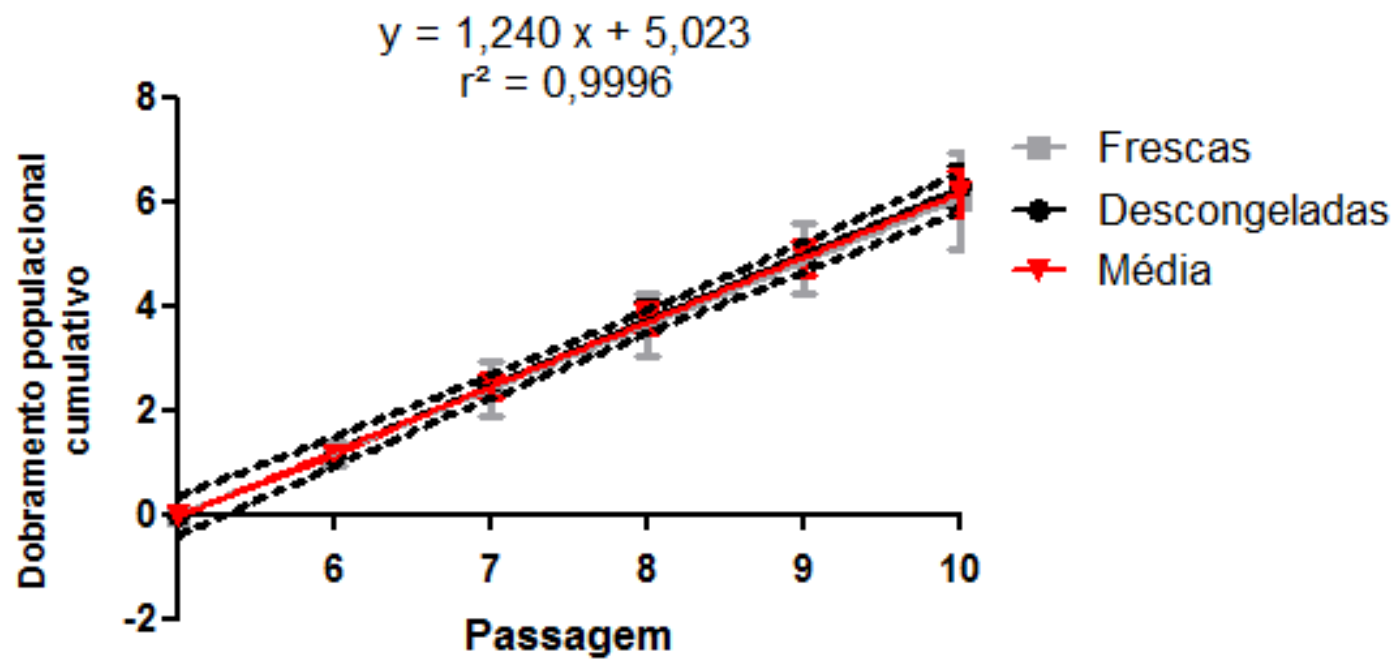

Figura 10: Índice de Dobramento Populacional Cumulativo (IDPC) médio de pASC em função das passagens. O gráfico acima demonstra o IDPC médio de pASC. Este dado foi obtido com base nos dados da figura 11. Note que não há decréscimo no potencial proliferativo das pASC avaliadas independentemente da condição ( $n$ células frescas $=4$ e $n$ células descongeladas $=3$ ) e uma relação linear do IDPC médio em função das passagens.

\subsubsection{Senescência}

Para complementar os dados relativos à cinética de crescimento das pASC fez-se necessário compreender como se deu o envelhecimento das células ao longo das passagens estudadas, para tanto, foi realizada a avaliação da senescência para pASC, submetidas ao congelamento e também para células frescas, entre as passagens 5 e 10 (Figura 11). 

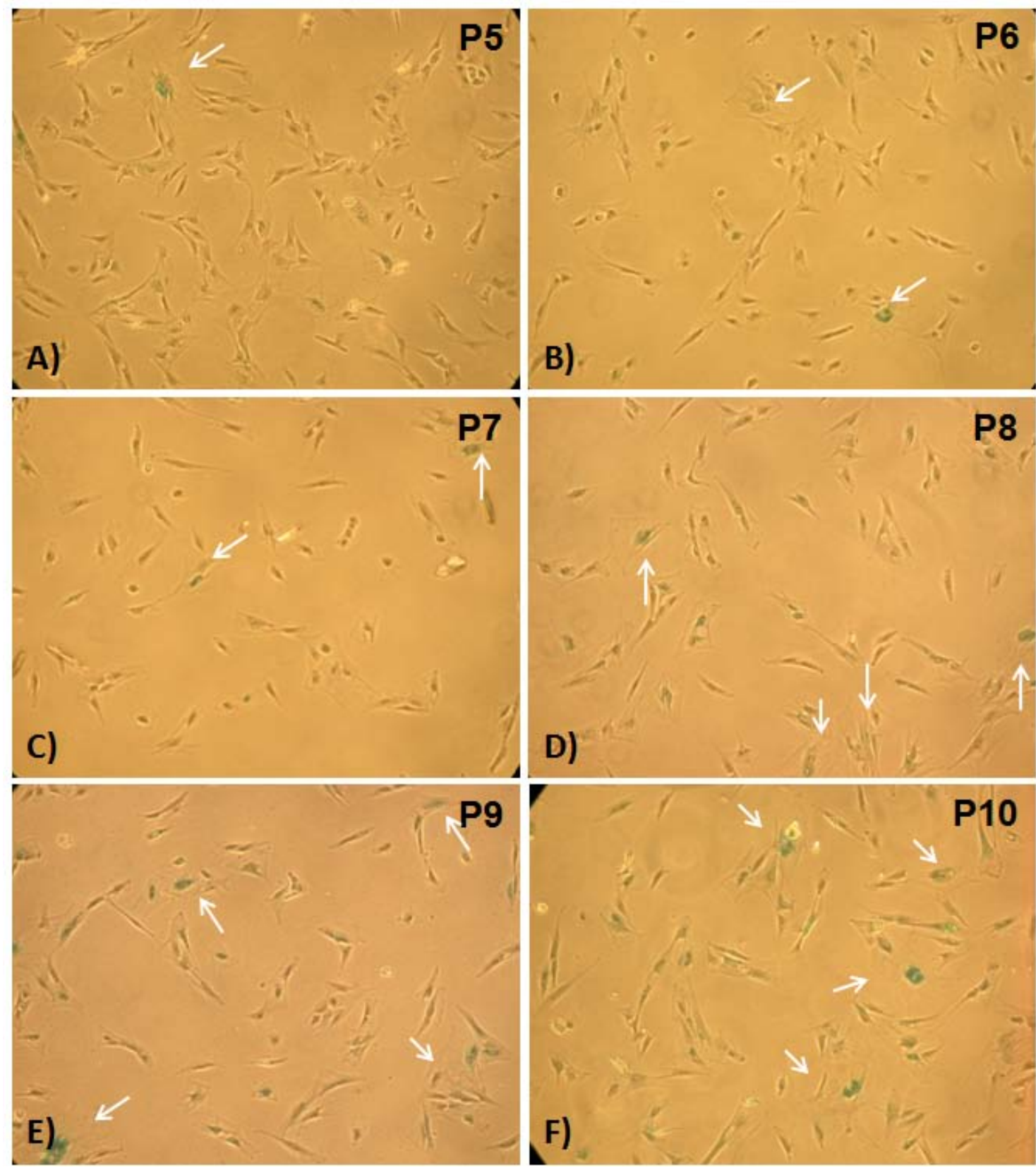

Figura 11: Senescência de pASC - Teste Citoquímico de SA- $\beta$-Gal . A) Imagem representativa de pASC em passagem 5. B) Imagem representativa de pASC P6. C) Imagem representativa de pASC P7. D) Imagem representativa de pASC P8. E) Imagem representativa de pASC P9. F) Imagem representativa de pASC P10. Note que as setas brancas evidenciam as células senescentes coradas em verde. Todas as imagens com magnificação de 100X.

Com o objetivo de comprovar a eficiência e exatidão do método do SA$\beta-G a l$, já que este é um método com alto grau de subjetividade e sujeito a respostas falso positivas, as contagens foram realizadas por operador cego 
Resultados

para o teste e dois grupos controle de senescência induzida com tratamento das pASC usando $\mathrm{H}_{2} \mathrm{O}_{2}$ foram produzidos. No primeiro grupo um tratamento com $200 \mu \mathrm{M}$ de $\mathrm{H}_{2} \mathrm{O}_{2}$ geraram 46,30\%₫0,78 de células senescentes, já no segundo tratamento, usando $400 \mu \mathrm{M}$ de $\mathrm{H}_{2} \mathrm{O}_{2}, 97,00 \% \pm 0,55$ das células tratadas tornaram-se senescentes (Figura 12).
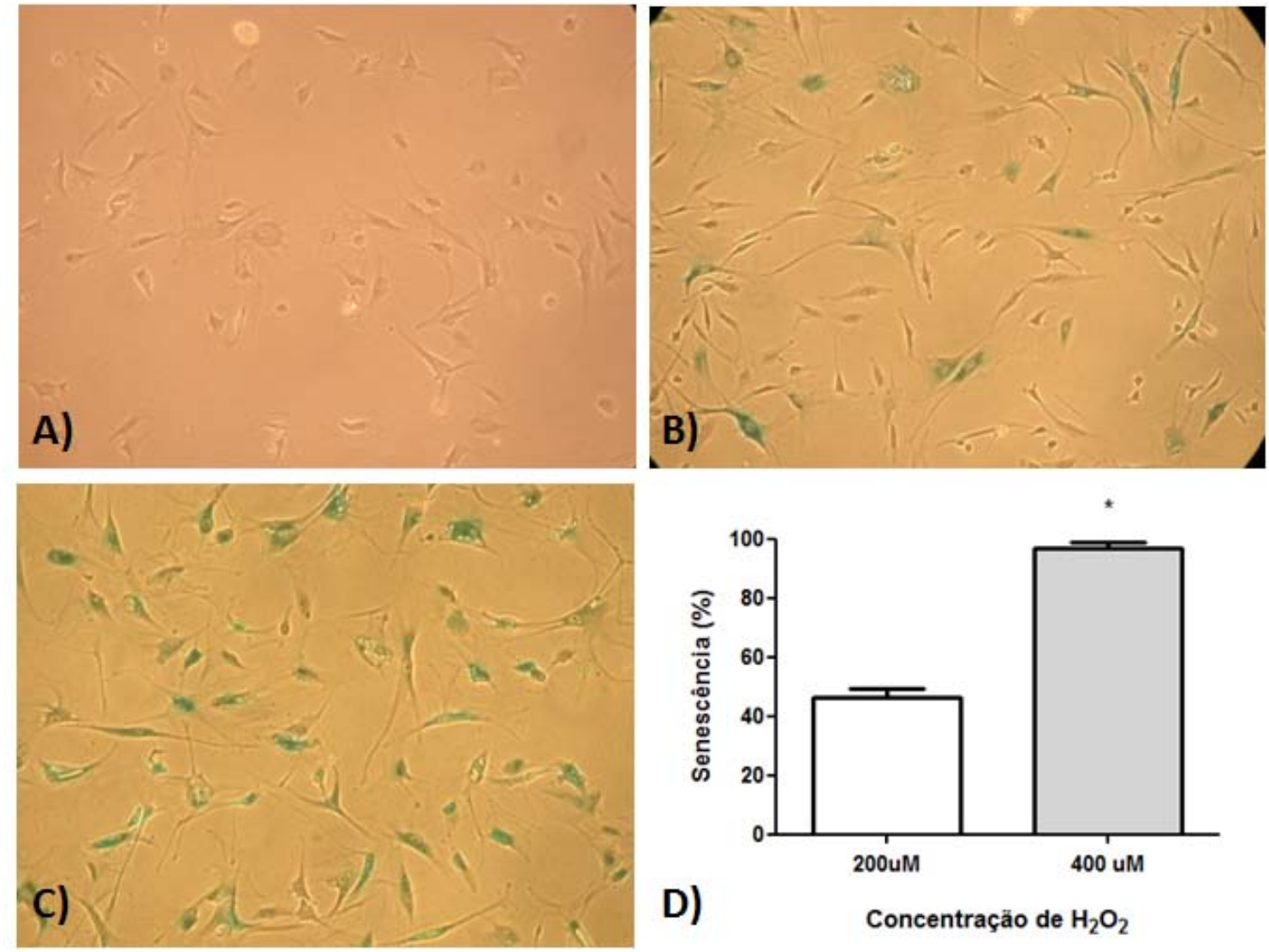

Figura 12: Controle positivo para senescência em pASC - Indução com $\mathrm{H}_{2} \mathrm{O}_{2}$. A) Imagem representativa de pASC após indução de senescência com $200 \mu \mathrm{M} \mathrm{H}_{2} \mathrm{O}_{2}$, antes da coloração pelo método citoquímico de SA- $\beta$-Gal . B) Imagem representativa de pASC após indução de senescência com $200 \mu \mathrm{M} \mathrm{H}_{2} \mathrm{O}_{2}$ e coloração pelo método citoquímico de SA- $\beta$ Gal. C) Imagem representativa de pASC após indução de senescência com $400 \mu \mathrm{M} \mathrm{H}_{2} \mathrm{O}_{2}$ e coloração pelo método citoquímico de SA- $\beta$-Gal. D) Gráfico de quantificação da porcentagem de células senescentes comparando a eficiência os dois tratamentos com $\mathrm{H}_{2} \mathrm{O}_{2}$ aplicados em pASC. Todas as imagens com magnificação de 100X.

Após validação do método e baseado na idéia do uso de células-tronco oriundas de banco de células para uso nas mais diversas terapias, onde não sejam necessários ciclos de reexpansão, é de extrema importância que ao 
Resultados

serem descongeladas as células apresentem parâmetros de crescimento, viabilidade e envelhecimento populacionais, muito bem estabelecidos na passagem de interesse, por isso, os resultados de senescência a cada passagem apresentados a seguir estão baseados nos dados obtidos para a passagem 5.

Os resultados obtidos demonstraram que apenas $3,25 \% \pm 0,26$ de pASC submetidas a ciclo de congelamento/descongelamento foram senescentes na passagem 5 enquanto 3,47\% $\pm 0,32$ células frescas foram senescentes nesta mesma passagem, não havendo diferenças estatisticamente significativas entre a porcentagem de células senescentes após descongelamento VS. células frescas $(p>0,05)$, dado este igualmente verificado à cada passagem avaliada (Figura 13).

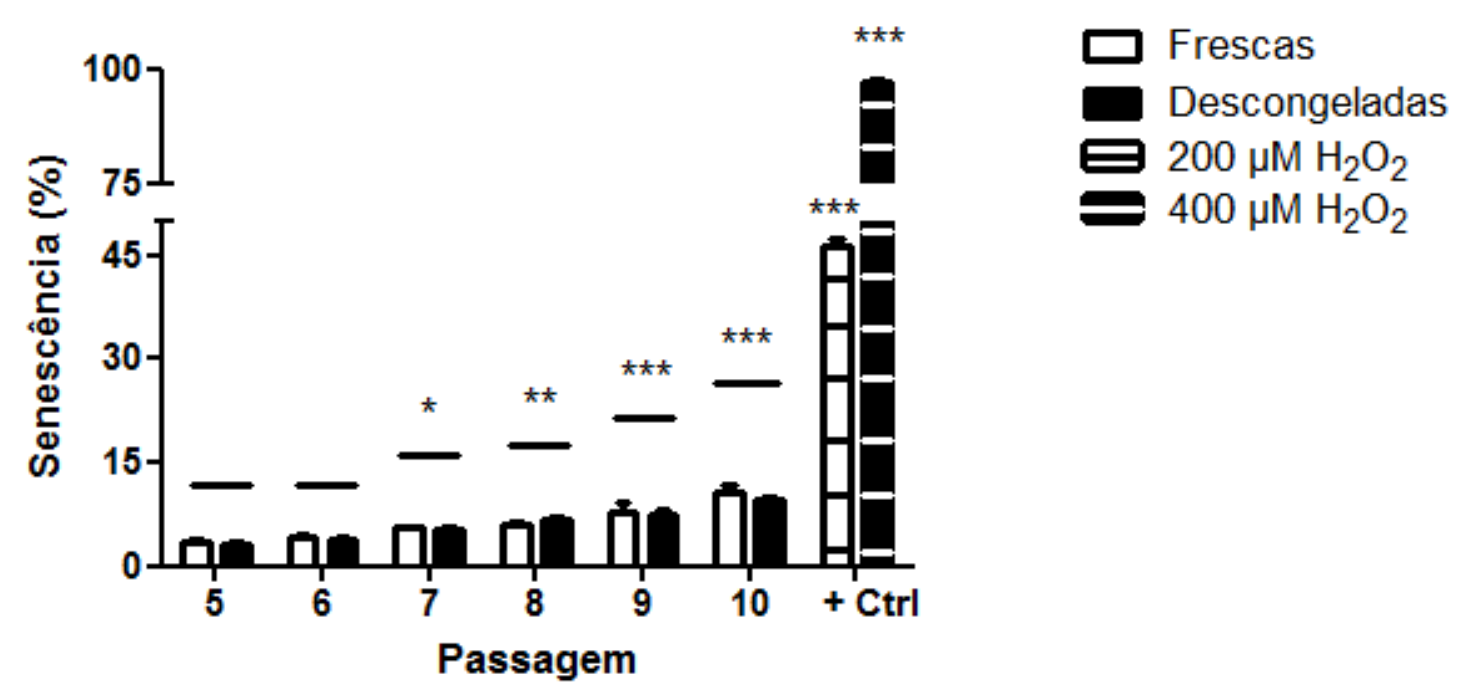

Figura 13: Senescência de pASC passagem 5 até 10. Não há diferenças estatisticamente significativas na porcentagem de células senescentes entre as condições de células frescas VS. descongeladas $(P>0,05)$, contudo diferenças estatisticamente significativas podem ser observadas quando comparamos as passagens 7 a $10 \mathrm{com}$ a passagem 5 , onde * $=$ $\mathrm{P}<0,05 ; * *=\mathrm{P}<0,01 ; * * *=\mathrm{P}<0,001$. P5 vs. $\mathrm{P} 6 \mathrm{p}>0,05$. 
Resultados

Entretanto, foi possível observar que houve um aumento significativamente lento e gradual na marcação positiva (verde) de células em nível de passagem, ao longo do período observado $(y=1,298 x+2,731$, onde $y=$ senescência média e $x$ é a passagem, $R^{2}=0,9698$, Pearson $R=$ 0,9848, Figura 14) refletindo um aumento na porcentagem de células senescentes neste intervalo, contudo, este aumento não excedeu $10 \%$ de células senescentes na passagem 10 (Figuras 11, 13 e 14).

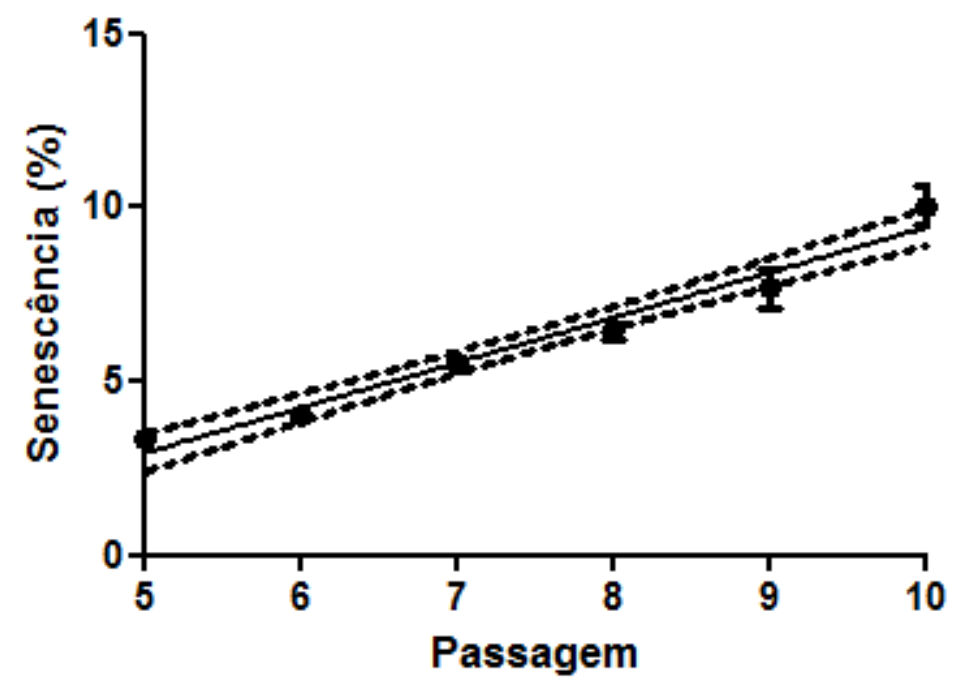

Figura 14: Gráfico de Regressão Linear para Senescência media de pASC em função das passagens. É possível observar um aumento gradual na porcentagem de células -tronco senescentes em função das passagens (Person $r$ frescas $=0,9694$ e descongeladas $=$ 0,$9895 ; R$ quadrado frescas $=0,9397$ e descongeladas $=0,9792 ; p<0,001 ;$ Regressão Linear - $p$ slope $>0,5)$.

Aliando os dados de proliferação celular e senescência populacional das pASC, fica claro que mesmo após o ciclo de congelamento/descongelamento, no período observado da passagem 5 até 10, estas células não sofrem alterações consideráveis, quando comparadas com células frescas. 
Resultados

Para uso futuro destas células em terapia celular, estes dados apontam para as passagens 5 e 6 como as mais seguras a serem exploradas, já que apesar do tempo de dobramento ser mantido constante durante todo o intervalo avaliado, há uma tendência de aumento deste parâmetro ao longo do tempo a partir da passagem 7. O que pode ser observado também para os parâmetros de envelhecimento da população de pASC em cultura independentemente do congelamento. Somados os dados de proliferação mais os dados de senescência, houve uma diminuição na capacidade proliferativa aparente das pASC a partir da passagem 7.

\subsection{Plasticidade das $p A S C$}

Além de serem capazes de se multiplicar gerando células-filhas não diferenciadas, as células-tronco podem, através de estímulos adequados, sofrer diferenciação para linhagens tecido-específicas. Diferentes passagens de pASC foram testadas (5-8) tanto em células congeladas como em células frescas, mas os resultados obtidos foram inconstantes.

\subsubsection{Diferenciação adipogênica}

As pASC cultivadas em meio de cultura suplementado para indução adipogênica demonstraram ao longo de três semanas um aumento gradual na quantidade de vesículas lipídicas intracelulares facilmente identificáveis sob microscópio invertido de luz (Figura 15), mas estas vesículas foram visualizadas apenas em nichos de células específicos espalhadas pela placa de cultura independentemente da condição (frescas ou descongeladas). 
Resultados
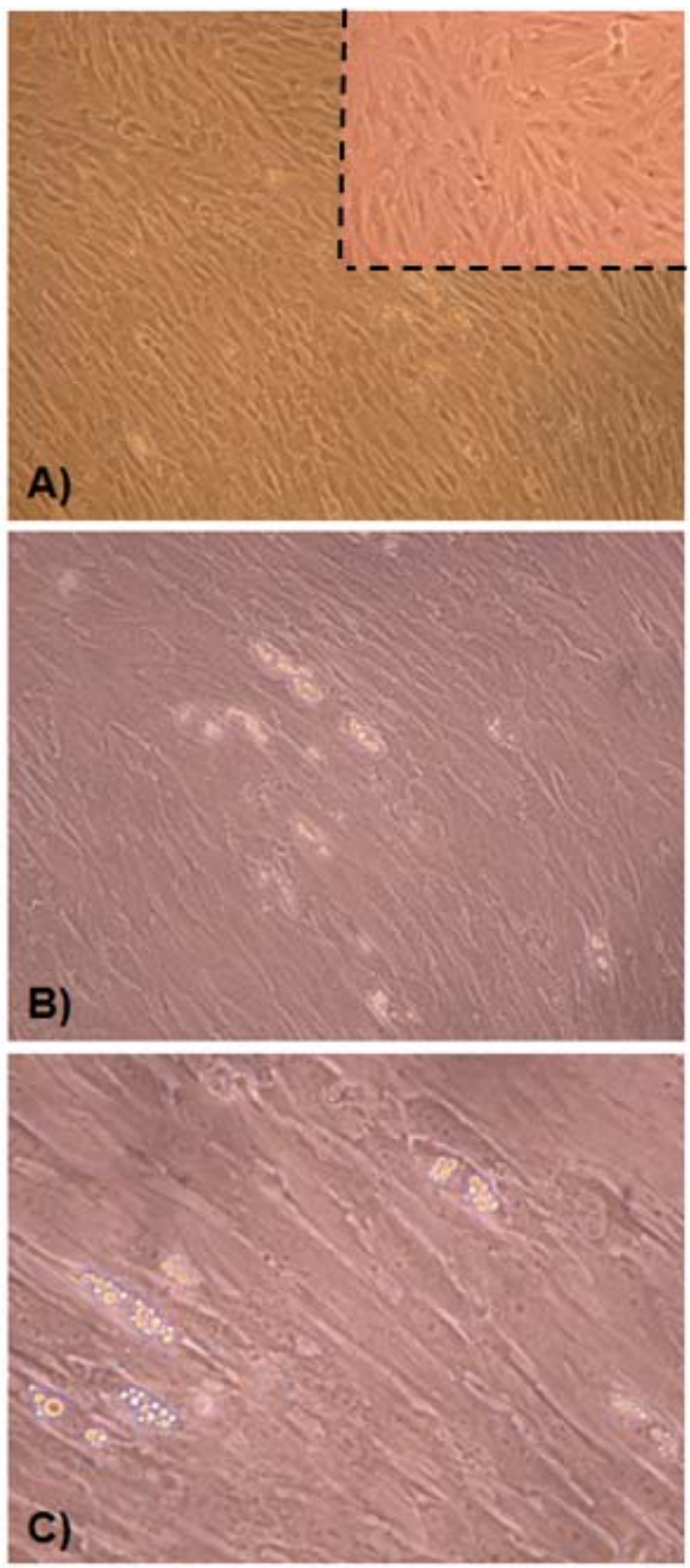

Figura 15: pASC induzidas com meio de diferenciação para linhagem adipogênica. A) Imagem representativa de pASC após 3 semanas do inicio de protocolo de indução. Note que o tamanho das vesículas lipídicas é pequeno, magnificação de 100X. No quadro superior esquerdo imagem representativa de PASC controle, mantida em meio de cultura suplementado apenas com 10\% de FBS. B) pASC após 3 semanas do início da indução. Note que as células que sofreram diferenciação estão esparsas pelo campo da imagem estão em menor quantia no total de células fotografadas, magnificação de 200X. C) pASC após indução, magnificação de 400X, note através do contraste da luz do microscópio que as vesículas são preenchidas por lipídio. 
Resultados

Para avaliar a eficiência da indução no fim de três semanas de protocolo, as células foram fotografadas e então fixadas e coradas com Oil Red $O$, que evidencia as gotículas lipídicas. Diferentes protocolos de coloração com ORO foram testados, mas todos eles acarretaram na perda das vesículas lipídicas intracelulares previamente fotografadas ficando visíveis apenas os vacúolos (Figura 16).
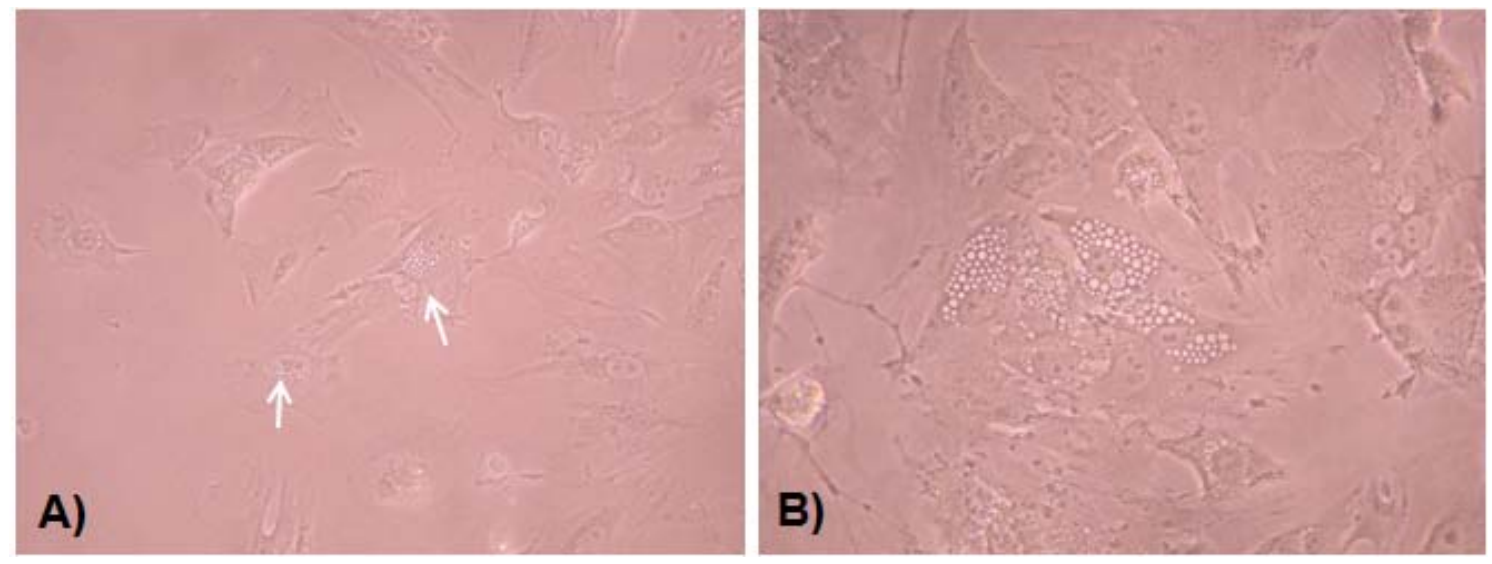

Figura 16: Linhagem adipogênica após protocolos de coloração com ORO. A) Imagem representativa de pASC após 3 semanas de indução para linhagem adipogênica logo após final do protocolo de coloração com ORO. Setas brancas apontam para células com vacúolos sem gotículas de lipídio, magnificação de 200X. B) Imagem representativa de pASC em magnificação de 400X, note em maior detalhe os vacúolos vazios.

Outra observação interessante feita comparativamente com célulastronco de humanos, usadas como controle, é que as vesículas lipídicas geradas pela indução das pASC são muito menores em diâmetro que as das células humanas, além de estarem presentes em menor quantidade (Figura 17). Ademais, somente $40 \%$ das tentativas de indução resultaram em células com morfologia esperada nos mais distintos meios de indução testados. 

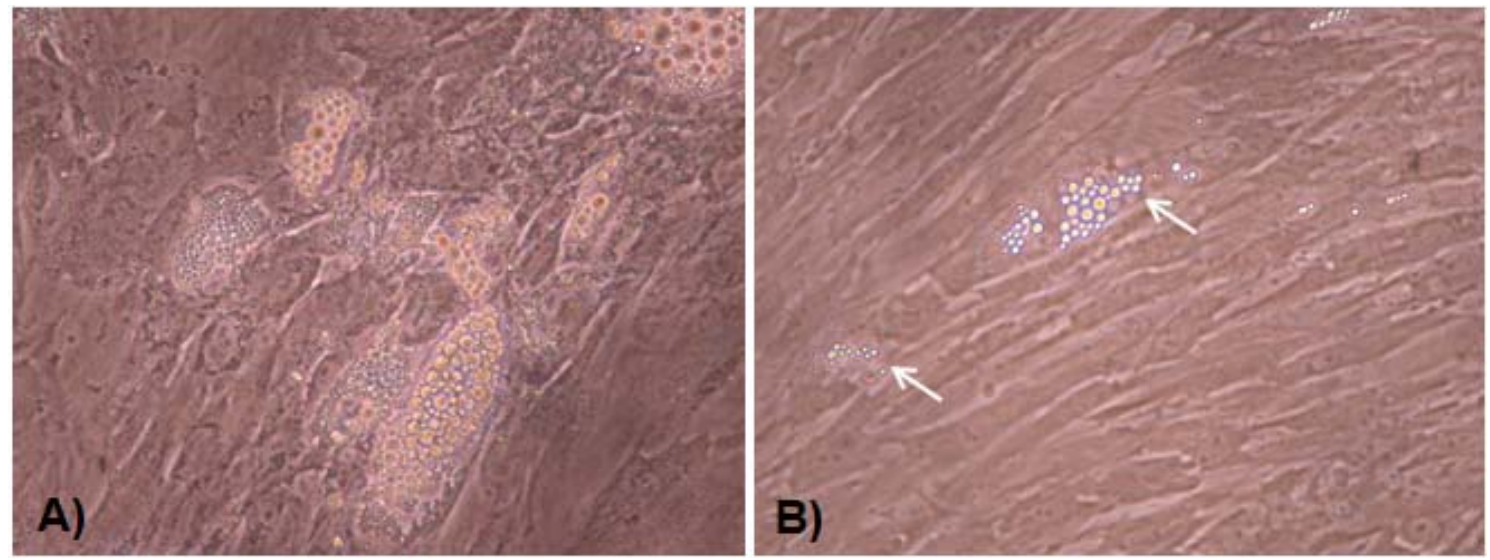

Figura 17: Diferença no diâmetro das vesículas lipídicas de hASC VS. pASC. A) Imagem representativa de hASC após 3 semanas de indução com meio de cultura suplementado com fatores pró-adipogênicos. B) Imagem representativa de pASC após 3 semanas de indução com o mesmo meio de cultura suplementado com fatores pró-adipogênicos usado para hASC da imagem A. Note a diferença clara na quantidade de vesículas em uma única células, bem como, o diâmetro das vesículas quem em hASC são consideravelmente maiores. Magnificação de 400X. 
Resultados

\subsubsection{Diferenciação osteogênica}

Após 3 semanas sob estímulo por cultivo em meio de cultura de indução osteogênica as pASC foram coradas com Alizarin Red S. Durante esse período modificações graduais na morfologia destas células foram observadas. As células curiosamente se organizaram em cristas (amontoados de células) que foram se alterando morfologicamente ao longo dos dias (Figura 18).
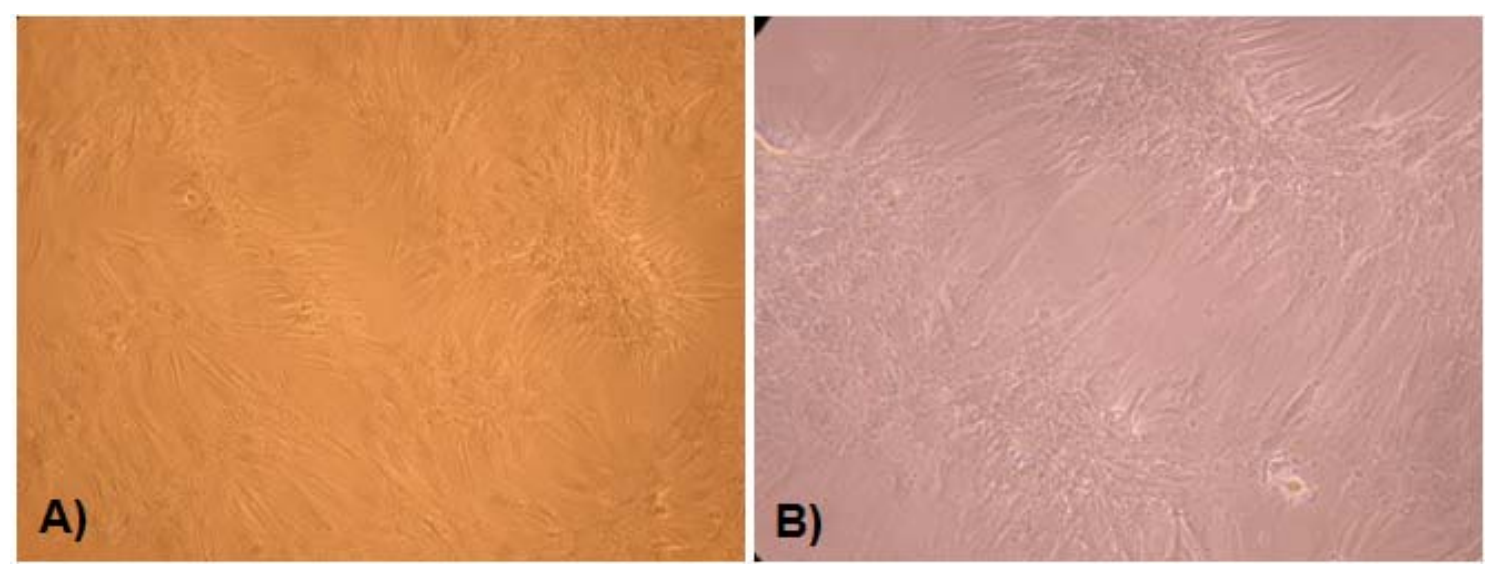

Figura 18: Organização em forma de crista de pASC após indução para linhagem osteogênica. A) Imagem representativa de pASC após 4 dias do início da indução para linhagem osteogênica. Note o rearranjo sofrido pelas células e o formato de cristas nas quais as células parecem se "amontoar". Magnificação de 100X. B) Imagem em magnificação de 200X evidenciando detalhes das cristas formadas pelas pASC após 3 semanas do início da indução de diferenciação para linhagem osteogênica.

Após a primeira semana foi possível observar algo como uma matriz mineralizada sendo depositada nas cristas de células. Ao final de 3 semanas foi confirmado pela coloração com ARS que a mineralização observada era verdadeira (Figura 19). 
Resultados
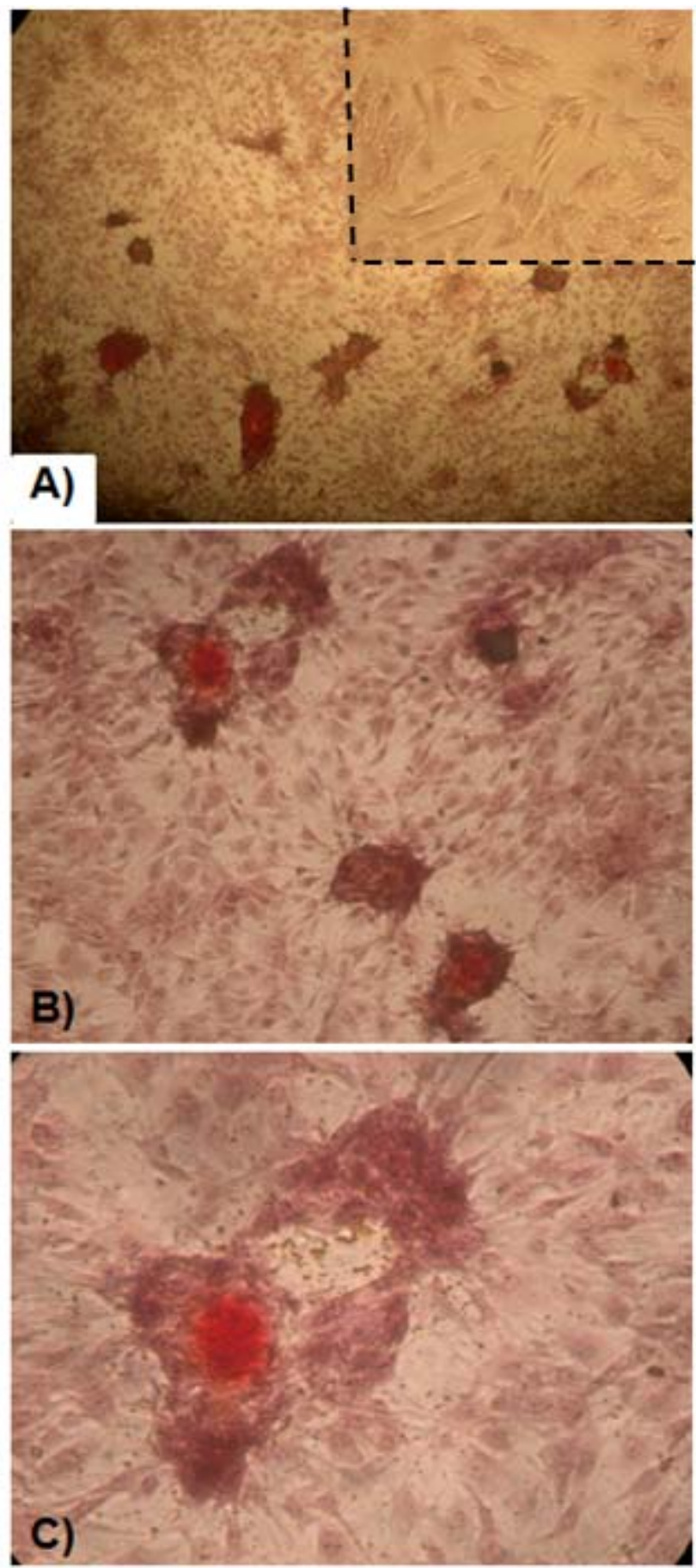

Figura 19: pASC induzidas com meio de diferenciação para linhagem osteogênica. A) Imagem representativa de pASC após 3 semanas do inicio de protocolo de indução e coloração com ARS. Note que as cristas coradas concentram-se principalmente na borda da placa de cultura, magnificação de 100X. No quadro superior esquerdo imagem representativa de pASC controle, mantida em meio de cultura suplementado apenas com $10 \%$ de FBS. Magnificação de 200X. B) pASC após coloração com ARS, magnificação de 200X. C) pASC após ARS. Note detalhes das cristas de pASC com cloração avermelhada denotando deposição de matriz mineralizada. Magnificação de 400X. 
Resultados

As células coradas, assim como na indução à adipogênese, foram visualizadas em nichos espalhados por toda a placa, mas principalmente nas regiões de borda. As células coradas apresentam focos de marcação avermelhada consistente com a deposição de cálcio, característica essa que demonstra o potencial das pASC em adquirir fenótipo de linhagem osteogênica. O mesmo não foi visualizado nas culturas controle, cultivadas em meio de cultura convencional (Figura 19 A quadro superior direito).

Contudo, apesar de as pASC apresentarem potencial para retenção de cálcio quando induzidas por meio de cultura suplementado, não mais que $20 \%$ das tentativas de diferenciação foram bem sucedidas.

\subsection{Experimentos com shear stress}

Após termos caracterizado pASC tanto em condições normais de cultivo como após ciclos de congelamento/descongelamento estas células foram submetidas ao estímulo físico de shear stress. Os experimentos foram realizados em diferentes condições e tempos e após os períodos de estímulo foram avaliadas características morfológicas, fenotípicas e também funcionais destas células.

\subsubsection{Análise morfológica de pASC - alinhamento celular}

As pASC foram submetidas a diferentes intensidades de shear stress e seu padrão morfológico foi visualizado, fotografado e comparado com pASC em condições estáticas. Quando submetidas às diferentes intensidades de shear stress $\left(1-3,5,15,25-30 \mathrm{dyn} / \mathrm{cm}^{2}\right)$ por curto período de tempo (até 30 minutos) nenhuma diferença morfológica, ou alteração na 
Resultados

disposição das células foi observada. No entanto, à medida que o tempo de exposição de pASC ao SS foi aumentado (24 e 48 horas, sob SS de 5, 10 e $15 \mathrm{dyn} / \mathrm{cm}^{2}$ ) observou-se alterações significativas na morfologia e organização destas células (Figura 20). Interessantemente, observou-se, nestas condições experimentais, que as pASC tiveram a tendência de se alinhar perpendicularmente ao fluxo gerado pelo sistema de SS (Figura $20 \mathrm{I}$ ).

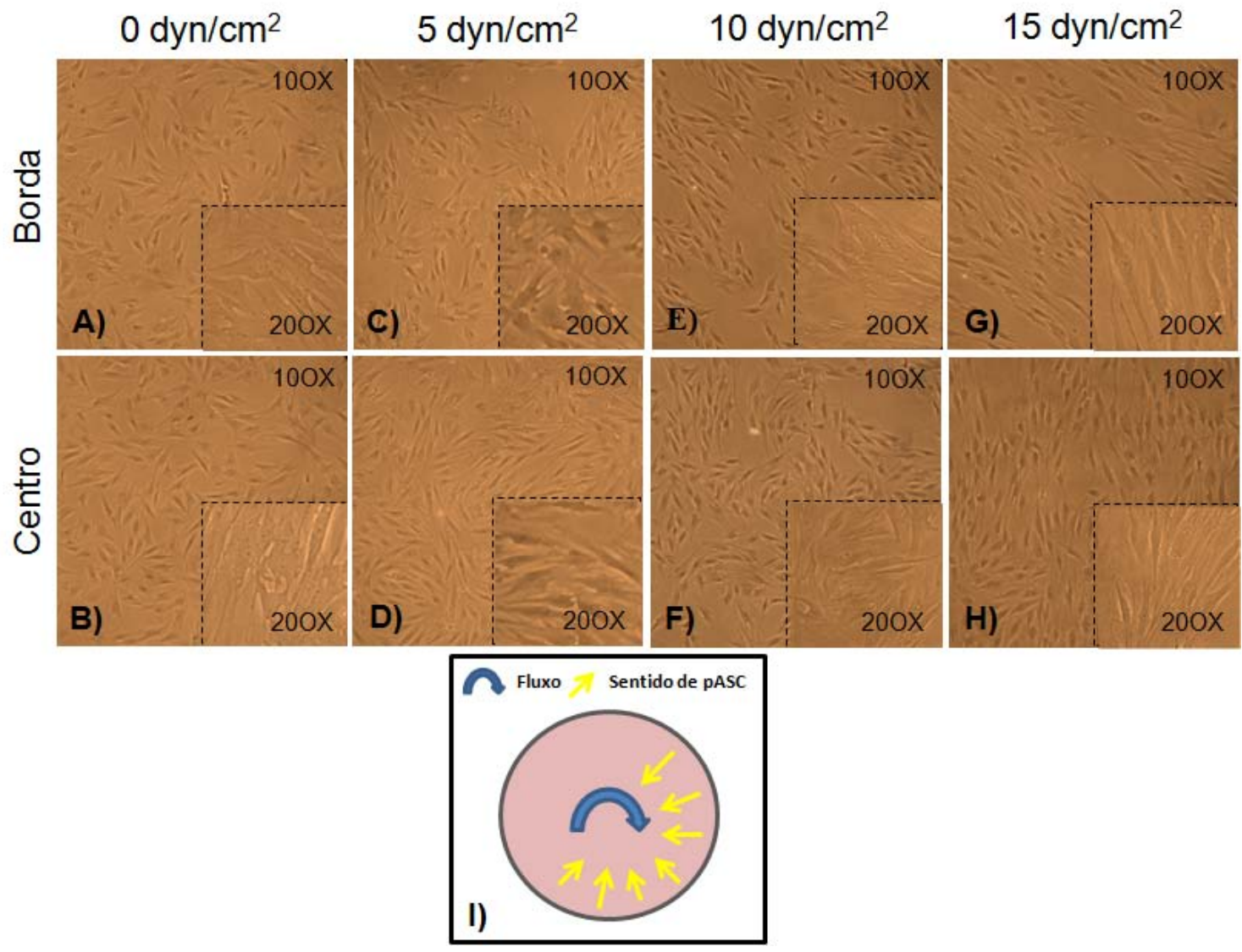

Figura 20: Morfologia de pASC após 48 horas de shear stress. A e B) Células controle em condição estática. C e D) pASC após 48 horas sob SS de 5 dyn/ $\mathrm{cm}^{2}$. E e F) pASC após 48 horas sob SS de $10 \mathrm{dyn} / \mathrm{cm}^{2}$. G e H) pASC após 48 horas sob SS de $15 \mathrm{dyn} / \mathrm{cm}^{2}$. Notar o formato fusiforme das células em G. As pASC tendem a se alinhar em direção ao centro da placa e essa organização aumenta conforme o aumento da intensidade do SS. I) Esquema da tendência de alinhamento das pASC após 48 horas submetidas ao shear stress. Magnificação de 200X. 
Resultados

\subsubsection{Análise de marcadores endoteliais em pASC submetidas ao SS}

Através das técnicas de citometria de fluxo, PCR quantitativo e western blotting as pASC foram analisadas, após serem submetidas por 48 horas ao shear stress de $15 \mathrm{dyn} / \mathrm{cm}^{2}$. O aparecimento de marcadores endoteliais e/ou alterações de marcadores mesenquimais foram avaliados.

Através da citometria de fluxo foi possível avaliar o tamanho e a granulosidade das pASC bem como a expressão dos marcadores de superfície que possibilitaram caracterizar a população de células-tronco. O padrão de tamanho e granulosidade das células não foram alterados significativamente quando submetidas ao SS por 48 horas (Figura 21).

\section{Estático}

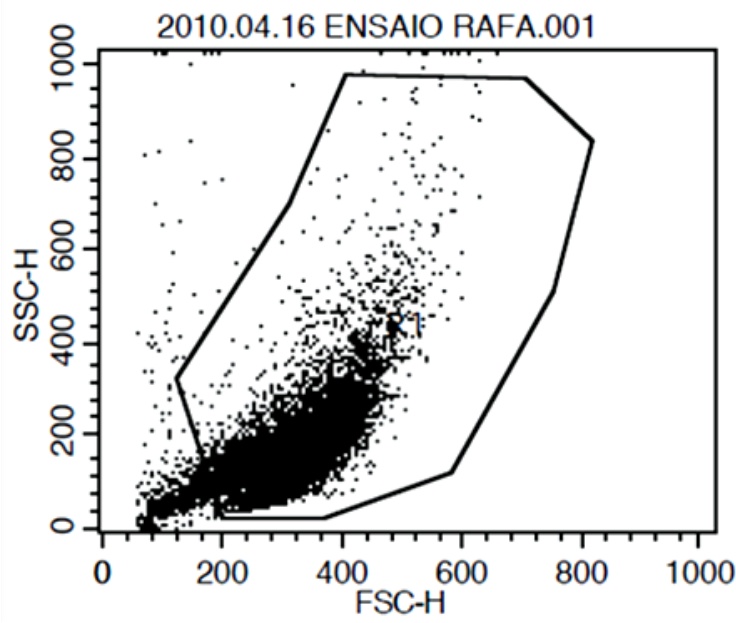

Shear Stress

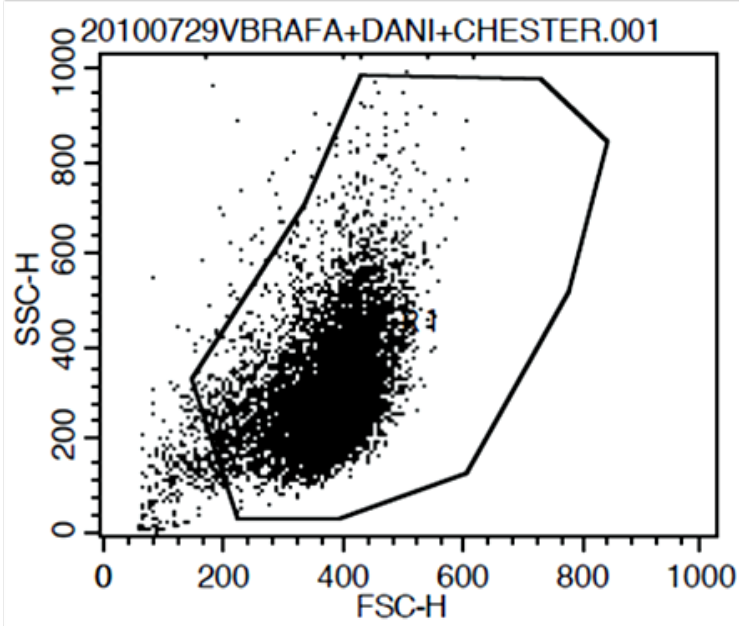

Figura 21: Gráfico de Tamanho (FSC) em função da granulosidade (SSC). Os polígonos representados (gates) evidenciam os eventos que foram considerados como células com tamanho e granulosidade adequadas as análises posteriores. Todos os procedimentos de análise foram realizados tanto para células estáticas como sob SS, sob as mesmas condições de calibração do citômetro de fluxo.

Ademais, as pASC submetidas ao estímulo de shear stress não apresentaram o marcador endotelial CD31. Nenhuma alteração significativa foi observada na expressão de marcadores de superfície mesenquimais 
Resultados

como CD29, CD90 e CD44 (Figura 22 A). O SS também falhou em modificar a expressão gênica de VE-Caderina, além da expressão de FLK-1 não ter sido identificada (Figura 22 B e C).

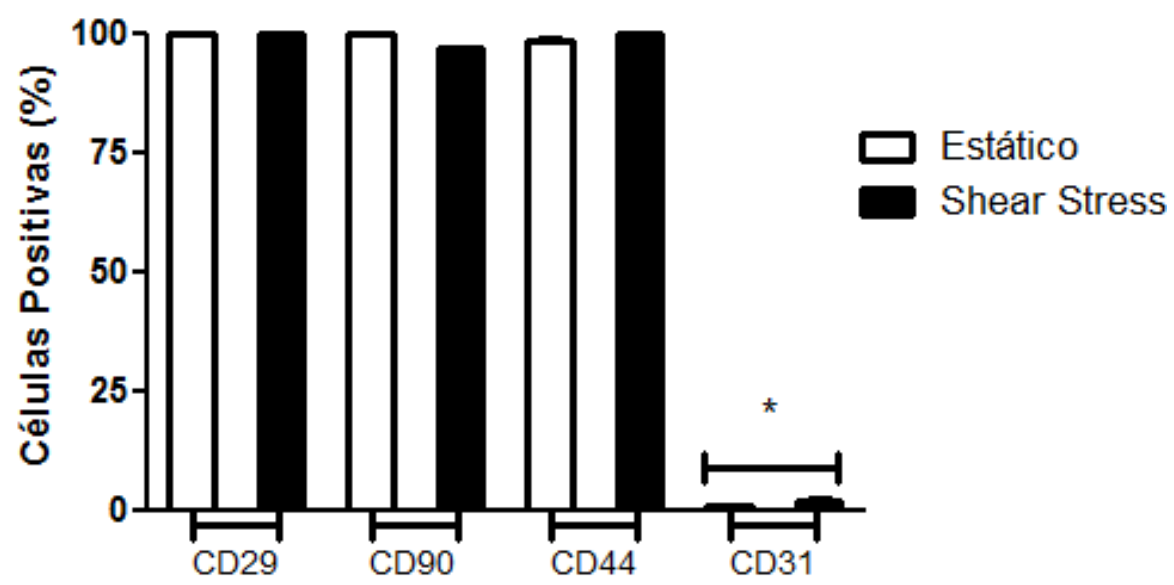

A)

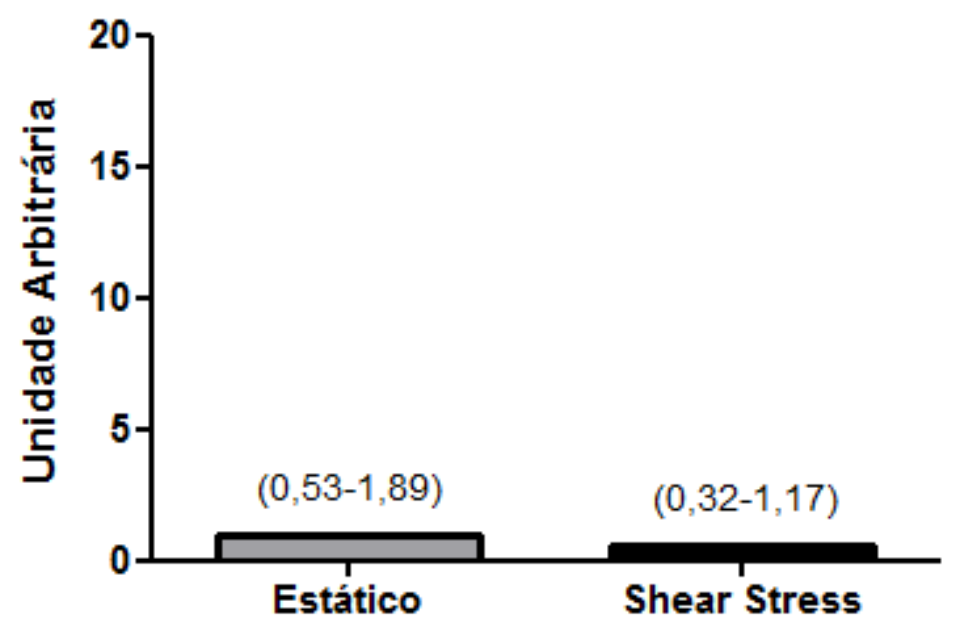

B) 
Resultados

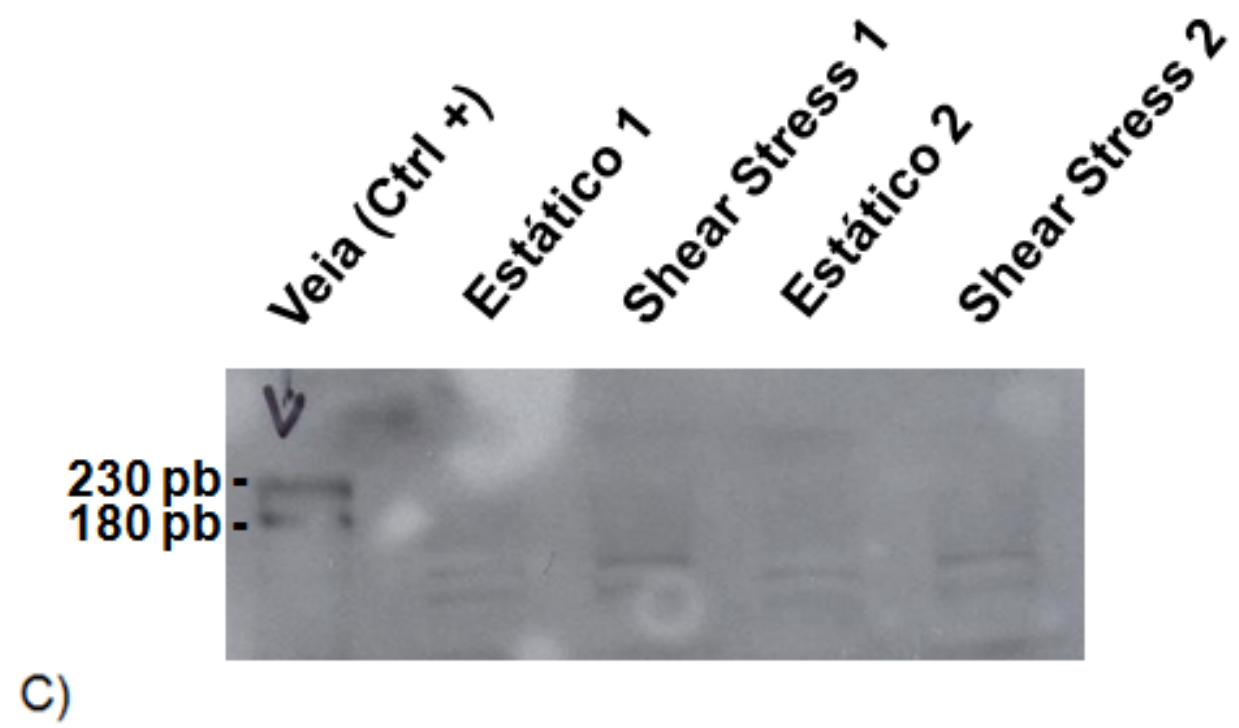

Figura 22: Análise de marcadores mesenquimais e endoteliais para pASC. A) Marcadores de superfície celular analisados por citometria de fluxo. Não há diferenças estatisticamente significativas entre as condições de célula estática e SS para nenhum dos anticorpos avaliados. * Notar que a expressão de CD31 é inferior a 3\% em ambas condições não sendo diferentes entre elas ( $\mathrm{N}=2$ ). B) VE-Caderina, outro marcador endotelial, foi avaliado através de PCR quantitativo. Não houve diferenças estatísticas significativas entre as condições, note intervalo de confiança sobre as barras $(\mathrm{N}=4)$. C) Note que além do controle positivo (Veia de porco), não houve expressão de proteínas FLK-1 em pASC, nem na condição estática, tão pouco na condição de shear stress $(\mathrm{N}=2)$.

\subsubsection{Dosagem de NO em pASC submetidas ao SS}

Apesar de o SS não provocar alterações no padrão fenotípico de ASC, alterações no perfil secretório destas células foram observadas. Motivados por dados prévios obtidos nesse laboratório com ASC humanas (27), avaliamos a liberação de óxido nítrico no meio de cultura, por pASC, em diferentes condições de tempo e intensidade de SS.

Inicialmente as pASC foram submetidas a $15 \mathrm{dyn} / \mathrm{cm}^{2}$ de SS por 48 horas. A cada 24 horas uma alíquota de meio de cultura foi coleta e posteriormente os íons nitrito foram dosados pelo método de Griess e então plotados no gráfico da figura 23. O shear stress induziu uma produção e liberação cumulativa de óxido nítrico em pASC. 


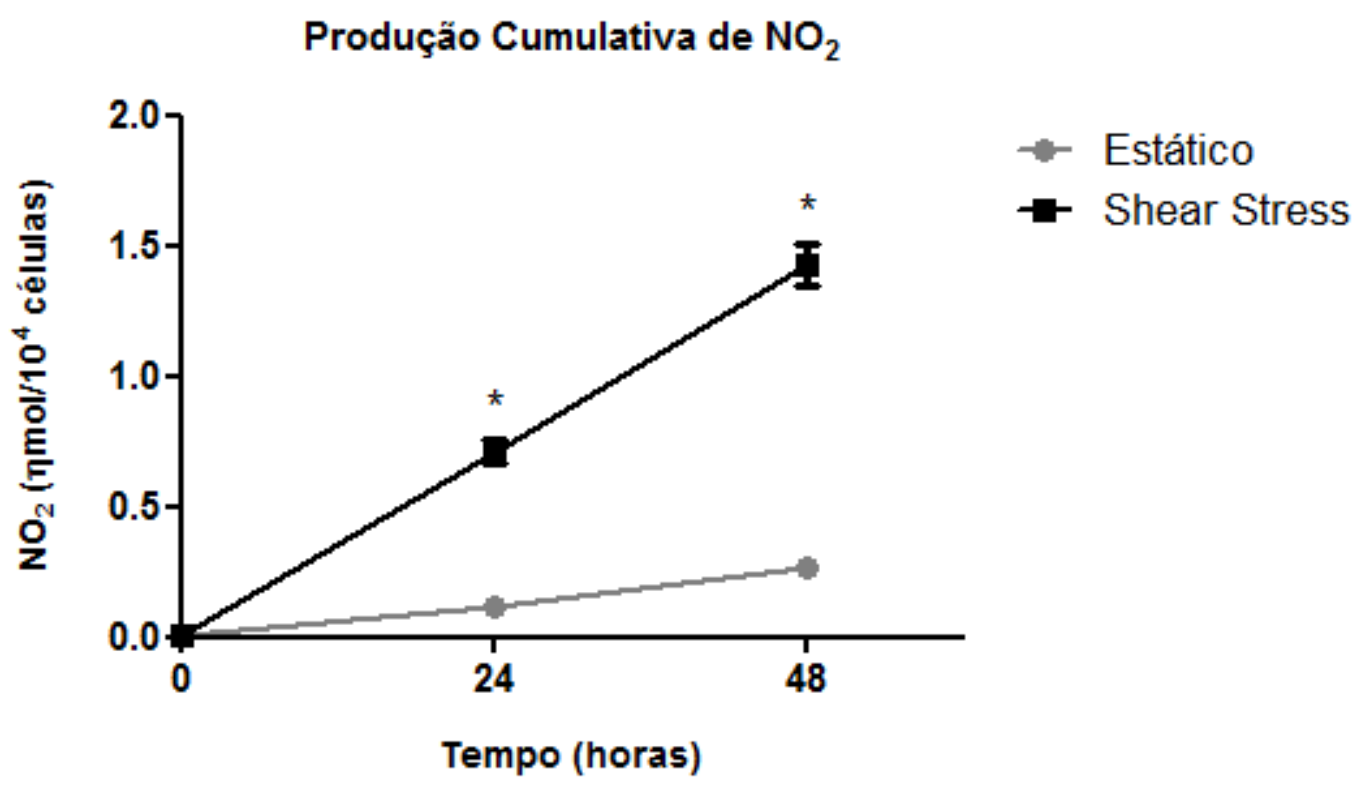

Figura 23: Shear stress induz a liberação de NO em pASC. Note que houve uma produção e liberação basal de óxido nítrico na condição estática de pASC. * para $p<0,05$, sendo $48 \mathrm{~h}$ SS diferente de $24 \mathrm{~h}$ SS e ambos diferentes de 24 e $48 \mathrm{~h}$ estático $(\mathrm{N}=7)$. Experimentos realizados em placas de $10 \mathrm{~cm}$.

Após confirmar que pASC são capazes de produzir e liberar óxido nítrico induzidas pelo SS, avaliou-se a síntese de NO para confirmar que esta se deu através de alguma das óxido nítrico sintases (NOS). pASC foram submetidas a shear stress de $15 \mathrm{dyn} / \mathrm{cm}^{2}$ por 24 horas, em meio de cultura suplementado um inibidor inespecífico de NOS (L-NAME). Após 24 horas de estímulo não foi possível observar diferenças entre os grupos SS e SS+L-NAME (Figura 24). 


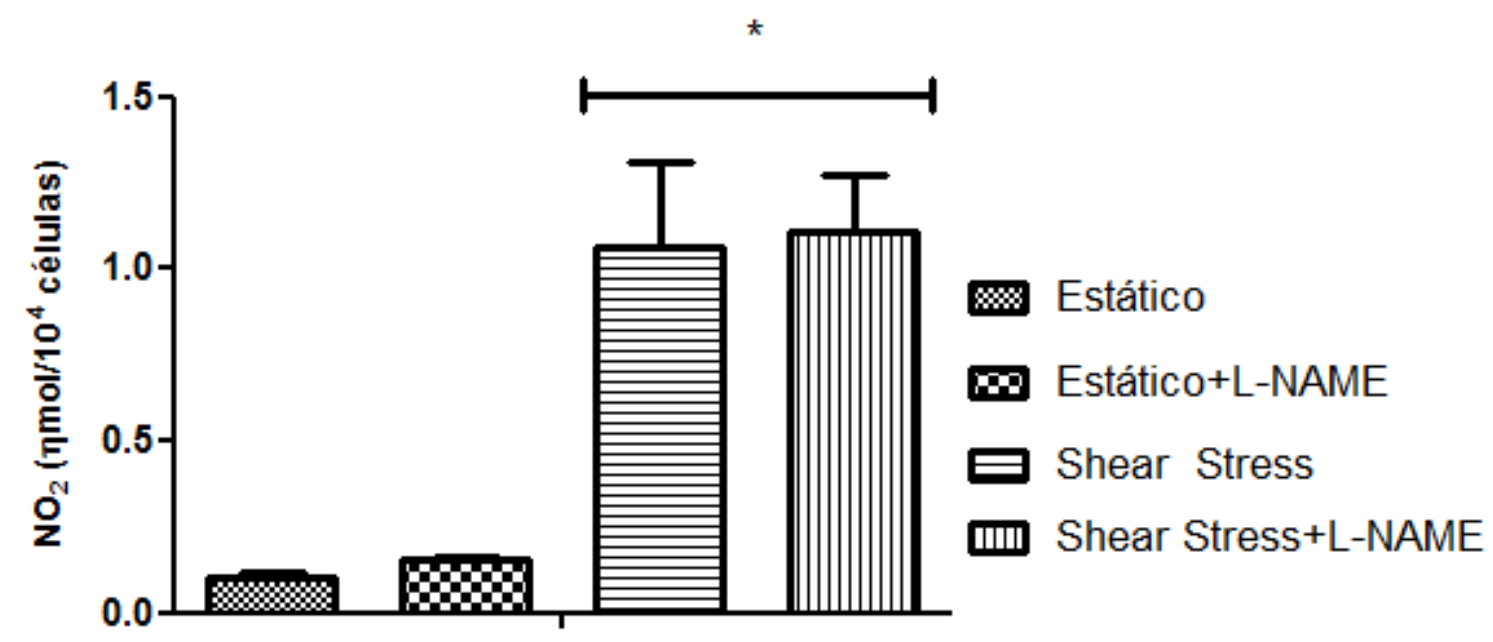

\section{Condição}

Figura 24: Shear stress induz a liberação de NO em pASC e esta não é bloqueada por LNAME após 24 horas de estímulo. * $p<0,05$, sendo SS diferentes das células em condição estática, mas não diferentes entre si $(\mathrm{N}=4)$. Experimento realizado em placas de $10 \mathrm{~cm}$.

Visto que 24 horas de SS não foram suficientes para demonstrar diferenças entre células submetidas ou não ao inibidor L-NAME, um experimento de 96 horas foi realizado para avaliar essa resposta ao longo do tempo. Coletas foram realizadas a cada 24 horas e posteriormente o método de Griess foi usado para dosagem de óxido nítrico no meio de cultura. Interessantemente ao longo do tempo (a partir de 48 horas) foi possível observar a inibição na liberação de NO (Figura 25) indicando que há relação entre o óxido nítrico produzido e a via de NOS. 


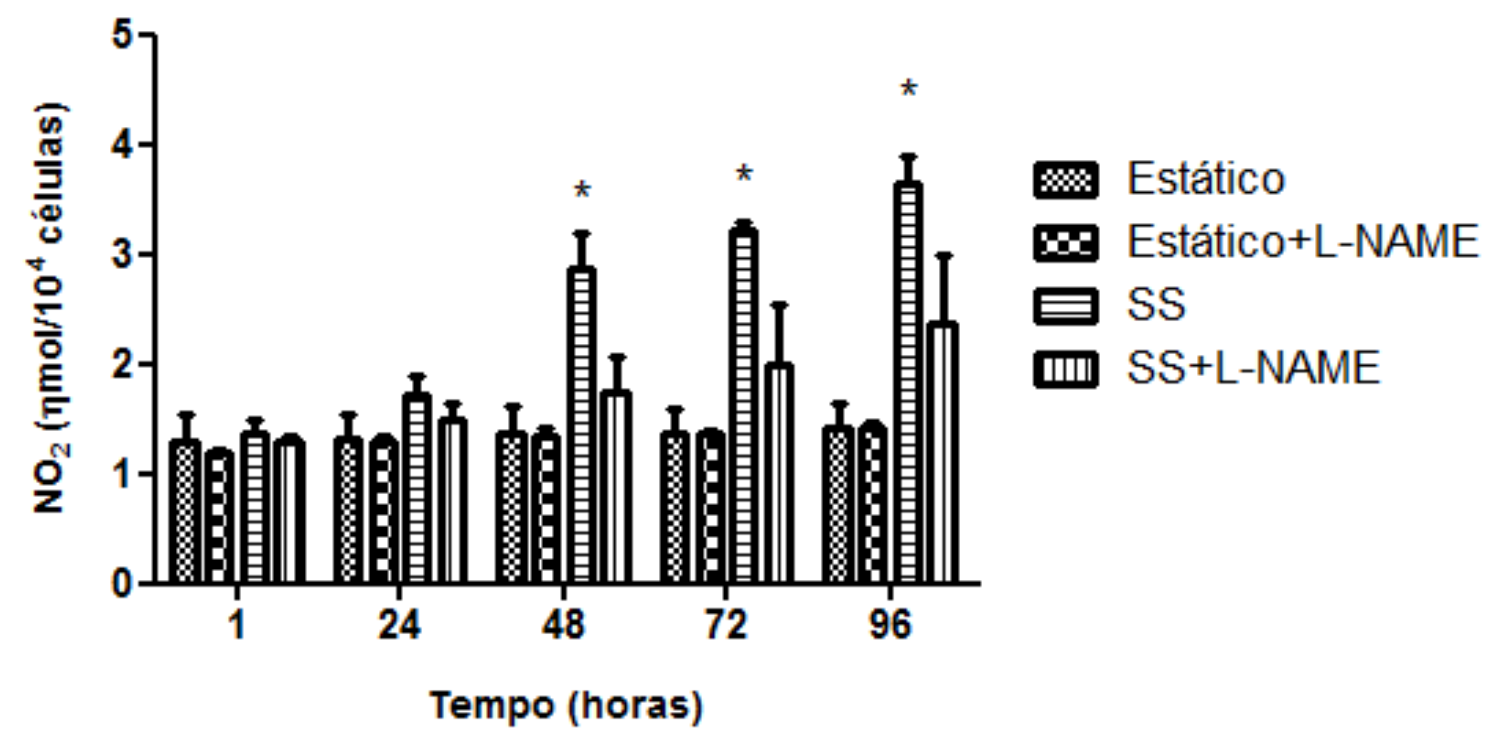

Figura 25: L-NAME bloqueia a atividade de NOS sob Shear stress reduzindo a liberação de NO em pASC. * $p<0,05$, sendo SS vs. células em condição estática e vs. células sob SS+L$\operatorname{NAME}(\mathrm{N}=3)$. Experimentos realizados em placas de $15 \mathrm{~cm}$.

\subsubsection{Dosagem de VEGF em pASC submetidas ao SS}

Considerando que é conhecida a alça de regulação entre o óxido nítrico e o VEGF, por exemplo, em células endoteliais, musculares lisas, linhagens cancerígenas e também em hASC $(36,49,50)$ onde o NO pode induzir a liberação de VEGF, neste trabalho foi verificado se as pASC são células produtoras de VEGF em condições estáticas, se essa produção é alterada quando essas células são submetidas ao estímulo mecânico de SS e se existe relação entre a produção de NO e VEGF.

Em um primeiro momento as pASC foram submetidas a $15 \mathrm{dyn} / \mathrm{cm}^{2}$ de SS por 48 horas (Figura 26 A). Ao fim de 48 horas as células foram lisadas com Trizol para posterior a expressão gênica de VEGF foi analisada por PCR quantitativo (Figura 26 C). Na figura 26 A é possível observar que as pASC apresentam uma produção basal, ainda que baixa, de VEGF quando em condição estática. Interessantemente foi observado que a 
Resultados

produção de VEGF é aumentada quando sob estímulo de SS. Verificamos também que após 48 horas o nível de expressão gênica de VEGF em pASC submetidas ao SS foi muito superior ao observado em pASC estáticas (Figura $26 \mathrm{C}$ ). Curiosamente, a taxa de produção de VEGF nas pASC submetidas ao SS não foi constante no período avaliado (Figura 26 B). Isto pode estar ocorrendo devido às condições experimentais aplicadas.

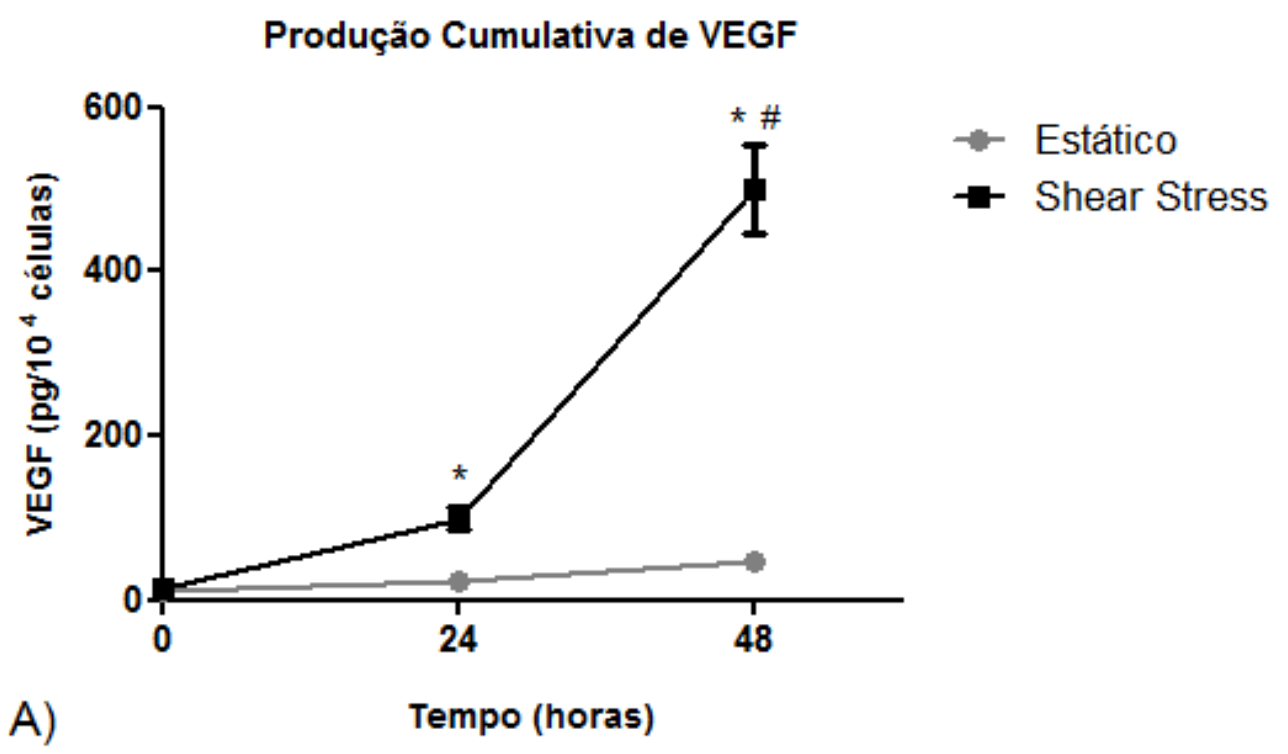

Taxa de Produção de VEGF por $10^{-4}$ células

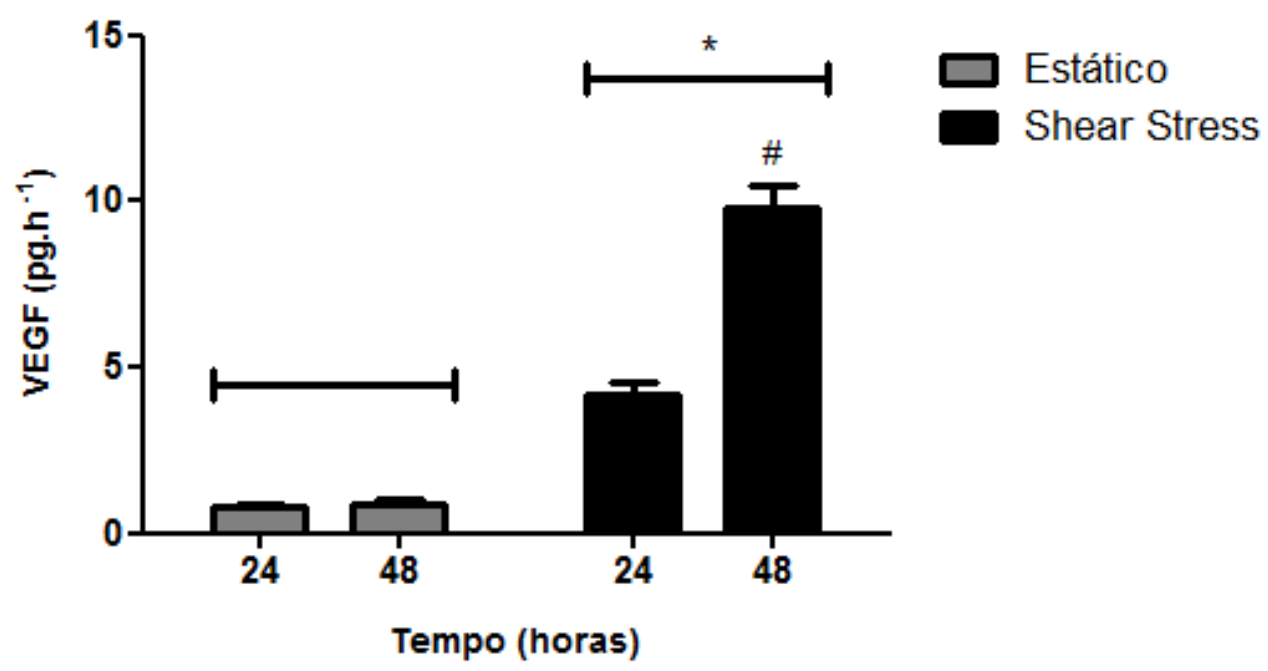

B) 


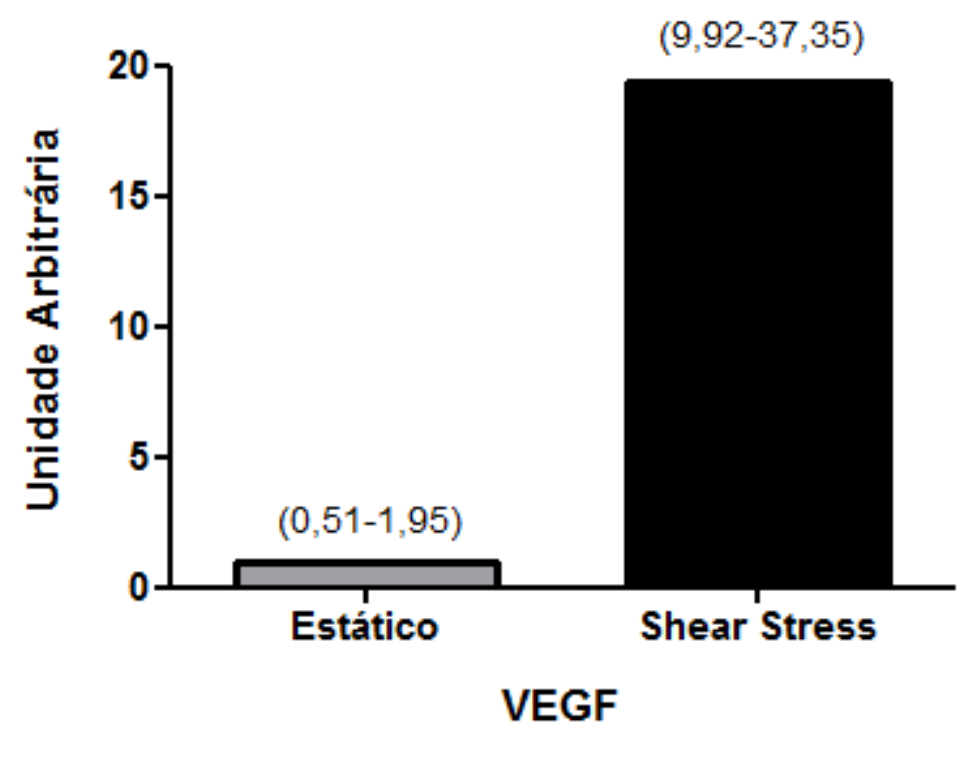

Figura 26: Shear stress induz a liberação de VEGF em pASC. A) Produção cumulativa de VEGF demonstrando diferença significativa entre SS e Ctrl e entre os tempos. B) Taxa de liberação de VEGF em pASC. Não há um aumento constante na produção de VEGF no intervalo e nas condições avaliadas. C) qRT-PCR para VEGF, mostrando aumento na expressão deste gene após $48 \mathrm{hr}$ de estímulo. * $\mathrm{p}<0,05,48 \mathrm{~h}$ SS e $24 \mathrm{~h}$ SS e ambos diferentes de 48 e 24 h estático respectivamente, $\# p<0,05,48 \mathrm{~h}$ SS diferente de $24 \mathrm{~h}$ SS $(\mathrm{N}=7)$. Experimentos realizados em placas de $10 \mathrm{~cm}$.

Testada a habilidade de pASC em produzir VEGF, foi investigada então a relação entre esta proteína e o NO. Como previamente demonstrado, quando as pASC foram submetidas a $15 \mathrm{dyn} / \mathrm{cm}^{2}$ de SS por até 24 horas, em presença do inibidor de NOS L-NAME, não foi possível detectar diferenças na liberação de NO comparativamente a células não inibidas. Sendo assim, o mesmo experimento de 96 horas de estímulo de SS utilizado para dosagem de $\mathrm{NO}$ ao longo do tempo e em presença de inibidor L-NAME, foi utilizado para dosagem de VEGF por ELISA. Os dados obtidos foram expressos no gráfico de barras da figura 27. 


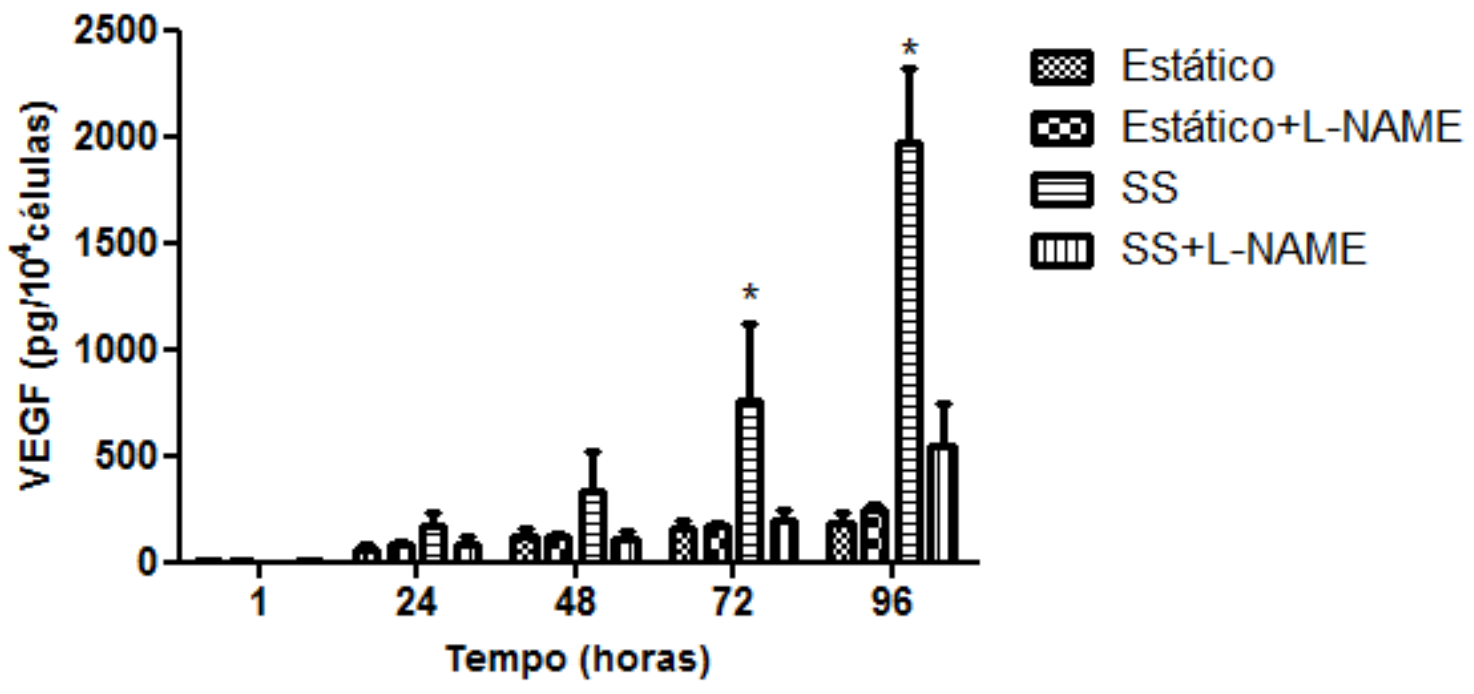

Figura 27: Shear stress induz a liberação de VEGF mediado por NO em pASC. Note a produção cumulativa de VEGF em 1, 24, 48, 72 e 96 horas após inicio do estímulo. * $\mathrm{p}<0,05$; Shear stress vs. Estático, Estático+ L-NAME e $\mathrm{SS}+\mathrm{L}-\mathrm{NAME}(\mathrm{N}=3)$. Experimentos realizados em placas de $15 \mathrm{~cm}$.

Esse gráfico demonstra que a partir de 72 horas houve diferenças estatisticamente significativas na produção de VEGF pelas pASC submetidas ao SS, quando comparadas com células nas mesmas condições, porém tratadas com inibidor de NOS. Juntos estes dados corroboram para a ideia de que a produção de VEGF é mediada pela produção e liberação de NO em pASC submetidas ao shear stress.

\subsubsection{Avaliação da fosforilação de ERK e AKT em pASC submetidas a curto período de SS}

Depois de demonstrado que o SS induz a produção de VEGF mediada por NO, avaliamos se essa produção pode estar relacionada com a via de sinalização ERK/AKT. Em uma primeiro experimento pASC foram submetidas a $15 \mathrm{dyn} / \mathrm{cm}^{2}$ de SS por 30,60 e 180 minutos (Figura 28). Observamos que o pico de fosforilação de ERK e também de AKT se dá aos 
Resultados

30 minutos de estimulação, comparativamente com os controles estáticos em cada tempo testado.

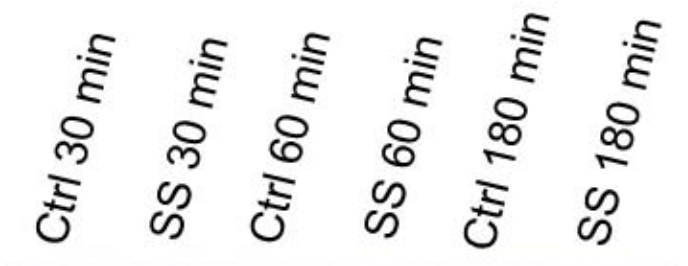

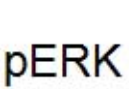

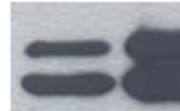

pAKT

\section{.}

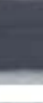

.

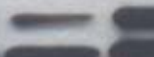

$44 / 42 \mathrm{kda}$

$60 \mathrm{kda}$

$\beta$-actina

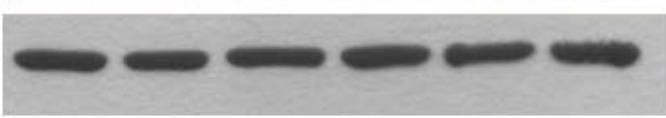

$47 \mathrm{kda}$
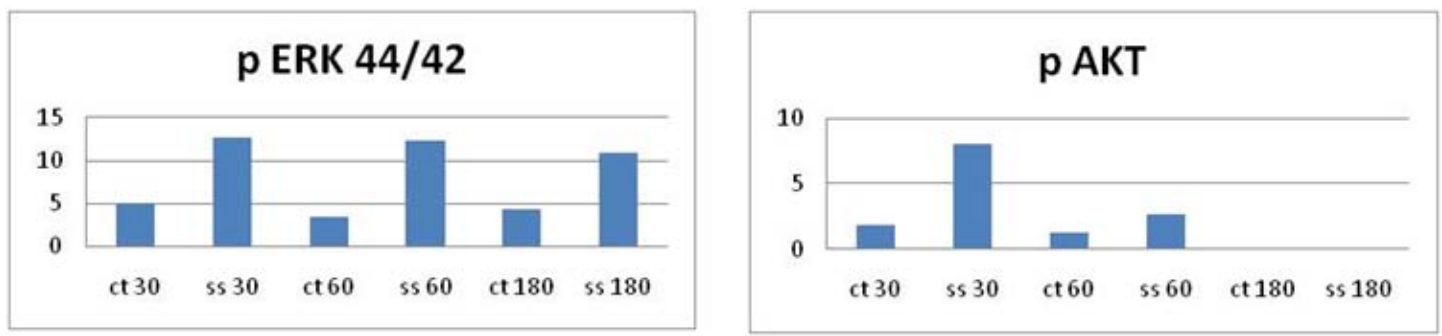

Figura 28: Pico de fosforilação de ERK e AKT em pASC submetidas a SS. Blotting representando a fosforilação da proteínas ERK e AKT e gráficos de quantificação por densitometria de bandas. Note que a fosforilação de ERK e AKT são superiores após 30 minutos de estímulo de SS comparativamente com células em condição estática e sob mesmo tempo para análise. $(\mathrm{N}=1)$. Experimentos realizados em placas de $10 \mathrm{~cm}$.

Baseado nesses resultados um novo experimento foi elaborado onde as pASC foram submetidas por 30 minutos a diferentes intensidade de SS $(1-3,5,15$ e 25-30 dyn/cm² ) e a fosforilação de ERK e AKT avaliadas. Para ERK observou-se uma fosforilação estatisticamente maior em 25-30 dyn/cm² comparado às células em condição estática (Figura 29). 


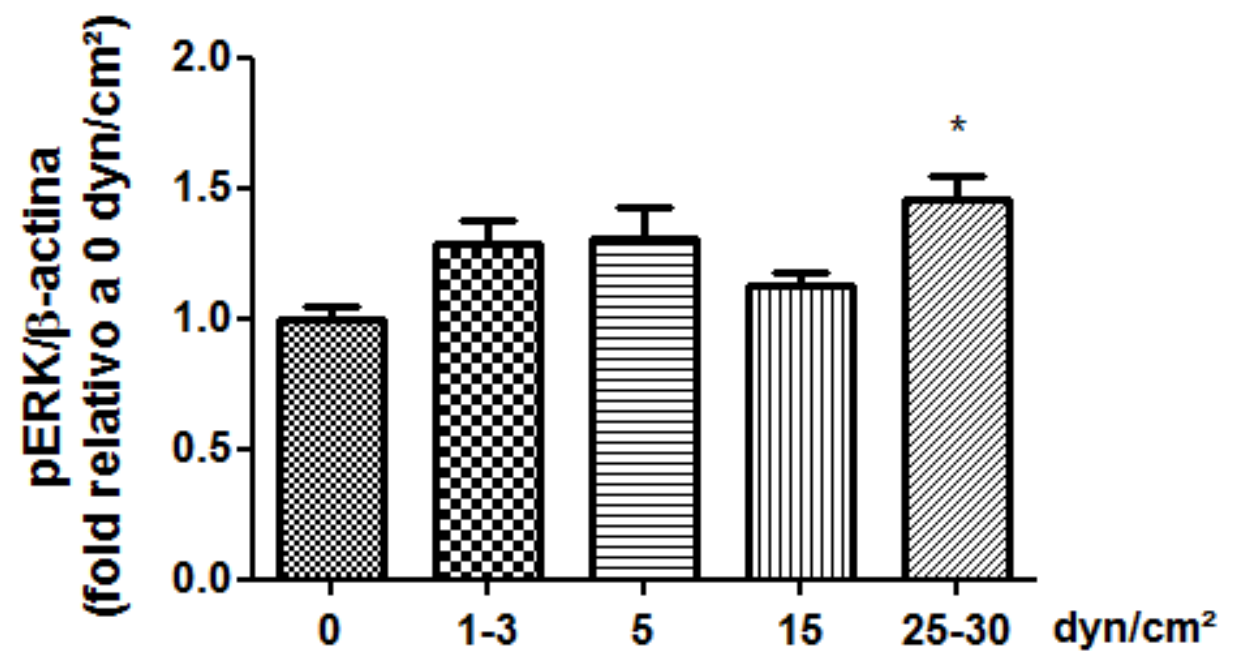

pERK

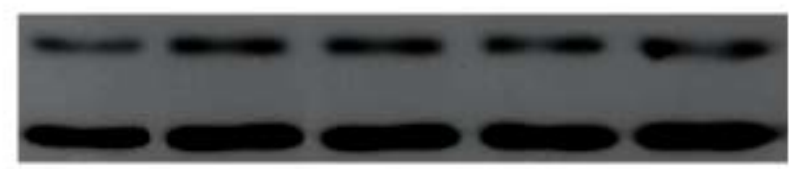

\section{$\beta$-actina}

Figura 29: Fosforilação de ERK em pASC submetidas a SS. Quantificação e blotting representativo para fosforilação de ERK após diferentes magnitudes de SS (* indica $p<0.05$ quando $25-30 \mathrm{dyn} / \mathrm{cm}^{2}$ vs. $\left.0 \mathrm{dyn} / \mathrm{cm}^{2} ; \mathrm{N}=4\right)$. Experimentos realizados em placas de $10 \mathrm{~cm}$.

Já para AKT observou-se uma fosforilação estatisticamente maior nos grupos 1-3, 5, 15 e 25-30 dyn/cm² versus o grupo de células estáticas e entre 1-3 dyn/cm² e os grupos 5 e 25-30 dyn/cm² (Figura 30). 
Resultados
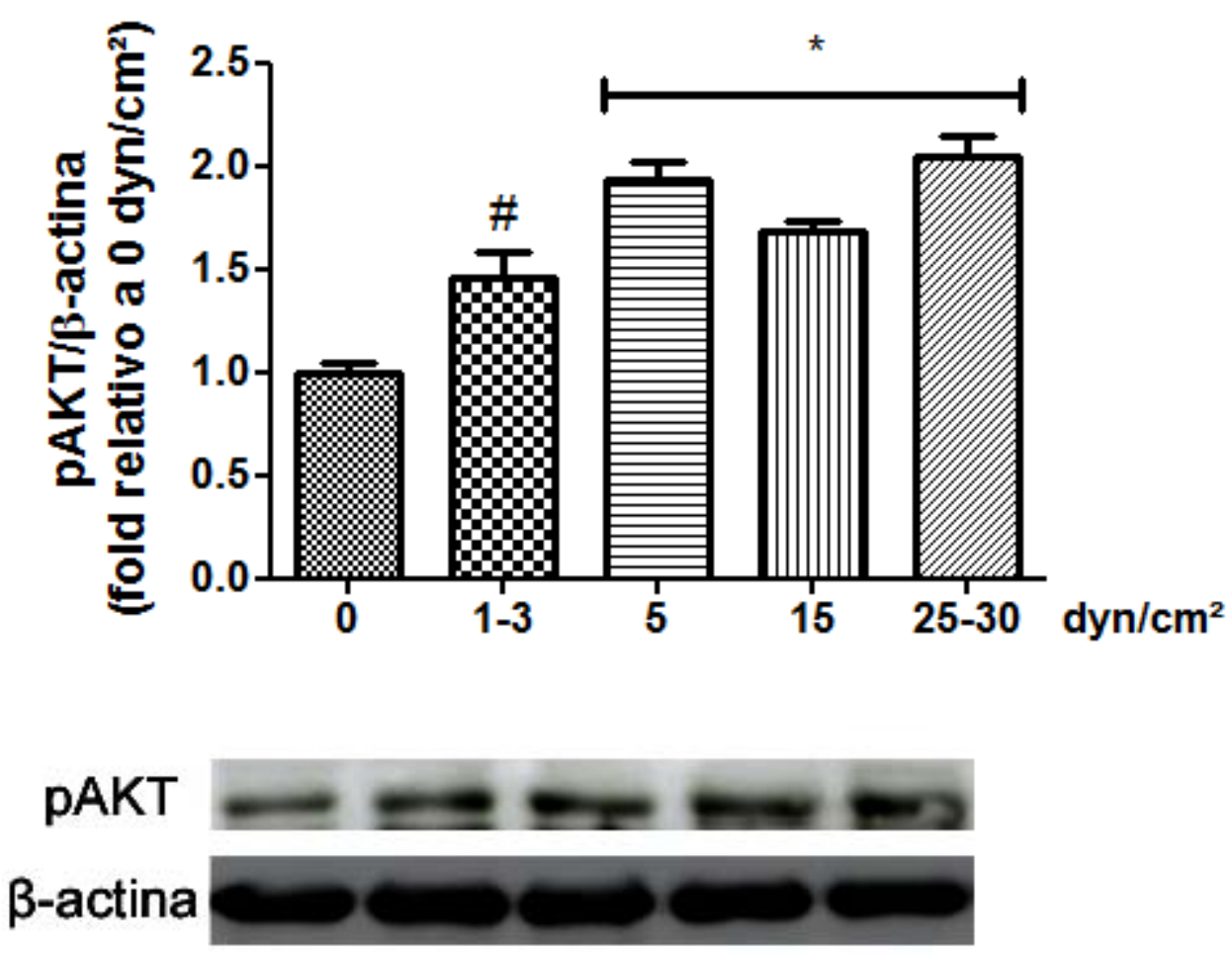

Figura 30: Fosforilação de AKT em pASC submetidas a SS. Quantificação e blotting representativo para fosforilação de ART após diferentes magnitudes de SS ( $p<0.05$ são indicados por * quando 5,15 e $25-30 \mathrm{dyn} / \mathrm{cm}^{2}$ vs. $0 \mathrm{dyn} / \mathrm{cm}^{2}$; \# quando $1-3 \mathrm{dyn} / \mathrm{cm}^{2}$ vs. 0,5 e $25-30 \mathrm{dyn} / \mathrm{cm}^{2} ; \mathrm{N}=4$ ). Experimentos realizados em placas de $10 \mathrm{~cm}$.

\subsubsection{Dosagem de NO e VEGF em pASC submetidas a diferentes magnitudes de SS}

Depois de ter sido demonstrado que o SS induz a produção de VEGF mediada por $\mathrm{NO}_{2}$ avaliamos se diferentes intensidades de SS podem alteram a produção de óxido nítrico e VEGF de forma significativa. Em um primeiro experimento as PASC foram submetidas a 30 minutos de SS de diferentes magnitudes $\left(1-3,5,15\right.$ e $\left.25-30 \mathrm{dyn} / \mathrm{cm}^{2}\right)$ no sistema para placas de $10 \mathrm{~cm}$. Medidas de nitrito e nitrato foram obtidas a dosagem de meio condicionado e os dados obtidos foram somados e corrigidos por volume e número de células e expressos no gráfico de barras da figura 31, 
Resultados

demonstrando não haver diferença na produção de NO em curto período de tempo.

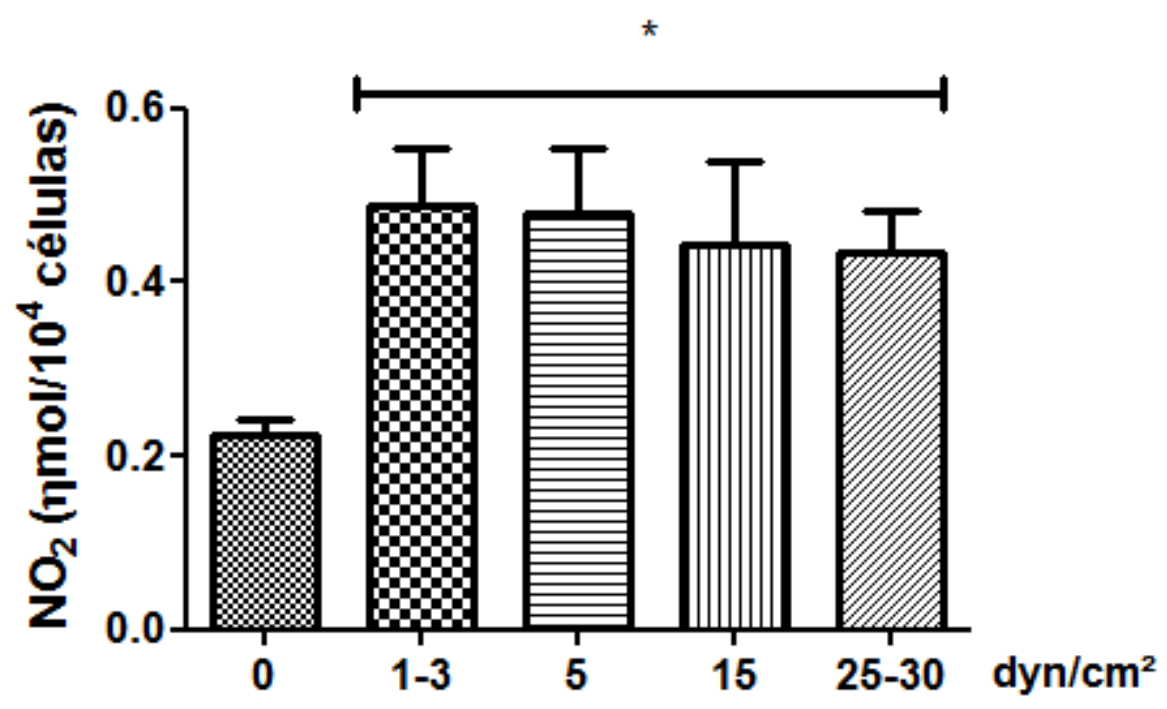

Figura 31: Diferentes intensidades de Shear stress de curta duração não alteram a liberação de NO em pASC. * $p<0,05$; Diferentes intensidades de Shear stress vs. Estático $(\mathrm{N}=4)$. Experimentos realizados em placas de $10 \mathrm{~cm}$.

Em um segundo momento, após observar que em curto período de estímulo as pASC não sofreram alterações significativas na produção óxido nítrico, estas células foram submetidas a diferentes intensidades de SS (5, 10 e $15 \mathrm{dyn} / \mathrm{cm}^{2}$ ) por até 48 horas. Nestas condições foi possível observar diferenças significativas na produção de NO (medida relativa de nitrito) bem como na produção de VEGF (Figura 32 A e B respectivamente). Também foram observadas diferenças significativas na expressão gênica de VEGF de pASC, por RT-PCR, nas diferentes intensidades de SS aplicadas após 48 horas de estímulo (Figura $32 \mathrm{C}$ e D). 

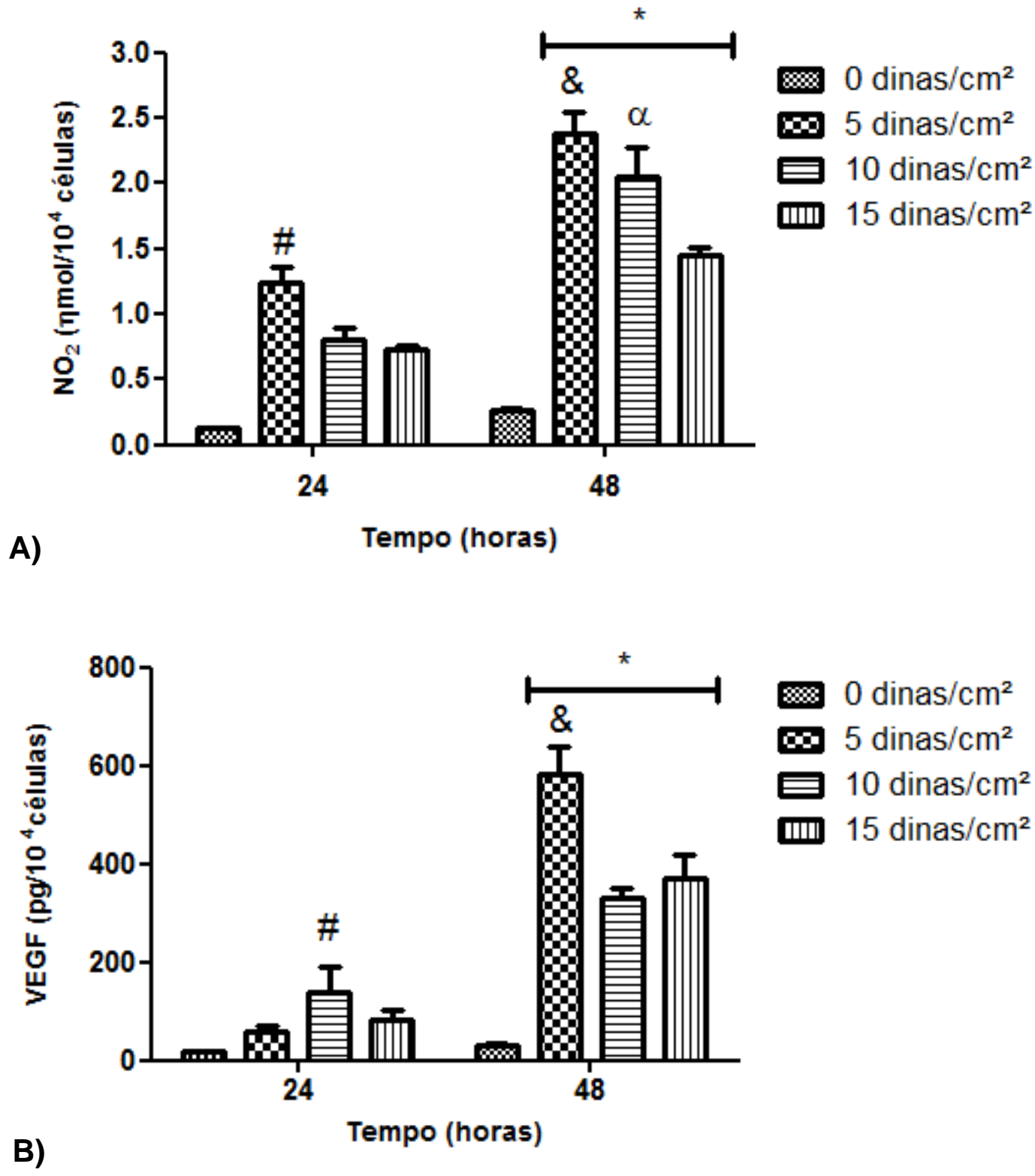
Resultados

\section{VEGF/28S}
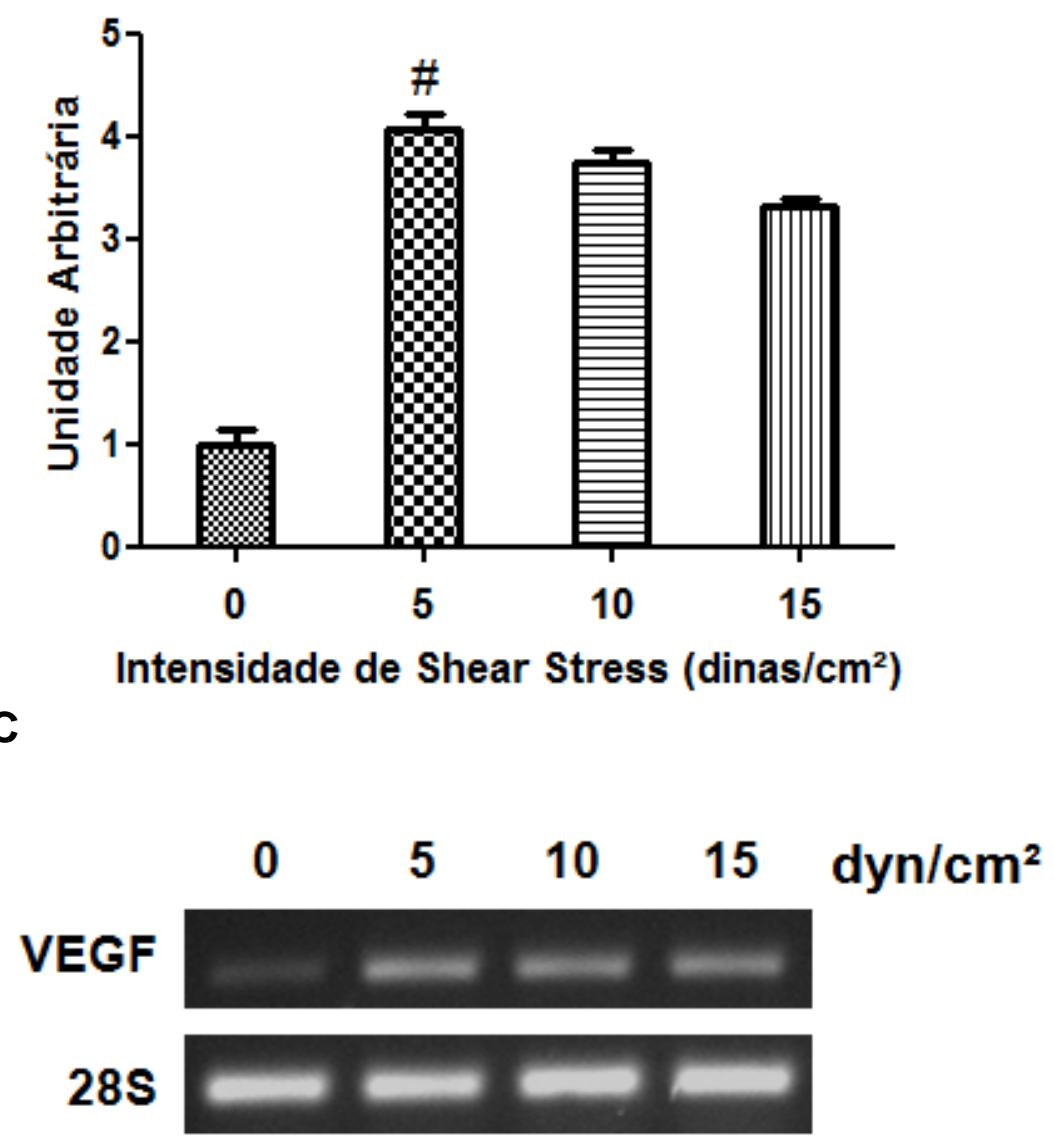

D)

Figura 32: Diferentes intensidades de Shear stress de longa duração induzem diferentes níveis de liberação de NO e VEGF em pASC. A) Produção de NO 24 e 48 horas após inicio do estímulo com 5, 10 e $15 \mathrm{dyn} / \mathrm{cm}^{2}$ de shear stress (* 5, 10 e $15 \mathrm{dyn} / \mathrm{cm}^{2}$ vs. 0 dinas $/ \mathrm{cm}^{2}$ e grupos 24 horas; \& 5 dyn/ $\mathrm{cm}^{2} 48$ horas vs. $15 \mathrm{dyn} / \mathrm{cm}^{2} 48$ horas; a $10 \mathrm{dyn} / \mathrm{cm}^{2} 48$ horas vs. $15 \mathrm{dyn} / \mathrm{cm}^{2} 48$ horas; \# $5 \mathrm{dyn} / \mathrm{cm}^{2} 24$ horas vs. 0, 10 e $15 \mathrm{dyn} / \mathrm{cm}^{2} 24$ horas; p<0,05. B) Produção de VEGF 24 e 48 horas após inicio do estímulo com 5, 10 e 15 dyn/cm² shear stress ( ${ }^{\star} 5,10$ e $15 \mathrm{dyn} / \mathrm{cm}^{2}$ vs. $0 \mathrm{dyn} / \mathrm{cm}^{2}$ e grupos 24 horas; $\& 5 \mathrm{dyn} / \mathrm{cm}^{2} 48$ horas vs. 10 e $15 \mathrm{dyn} / \mathrm{cm}^{2} 48$ horas; \# $10 \mathrm{dyn} / \mathrm{cm}^{2} 24$ horas vs. 0, 5, e $15 \mathrm{dyn} / \mathrm{cm}^{2} 24$ horas; $\mathrm{p}<0,05$. C) Quantificação de RT-PCR Semi-quantitativo demonstrando expressão de VEGF. * 5 dyn $/ \mathrm{cm}^{2}$ vs. 0 e $15 \mathrm{dyn} / \mathrm{cm}^{2} ; p<0,05$. D) Gel de agarose representativo do RT-PCR semiquantitativo de VEGF $(\mathrm{N}$ de todos os experimentos $=4$ ). Experimentos realizados em placas de $10 \mathrm{~cm}$.

Juntos os dados acima demonstraram que as diferentes intensidades de shear stress aplicadas à pASC induziram diferentemente a produção tanto de óxido nítrico com de VEGF. 
5. Discussão 
Discussão

Nossos dados demonstram características das células-tronco mesenquimais derivadas do tecido adiposo de suínos em cultura, após uma extração em grande escala e processo de criopreservação. Usando as metodologias descritas, fomos capazes de colher células de gordura subcutânea de quatro porcos, sendo um deles um doador e os outros 3 animais usados para comparações entre as condições estudadas. Durante os primeiros dias em cultura foi possivel observa alguns pequenos nichos de células com caracteristicas endoteliais, no entanto por volta da passagem de 4 estas poucas células desapareceram e a cultura passou a apresentar apenas células com morfologia de fibroblastos. Esta morfologia é consistente com ASC de roedores e humanos $(9,28)$.

Duas semanas após a extração, em passagem 4, foram obtidas cerca de 3 bilhões de células $\mathrm{CD}^{+} 9^{+}, \mathrm{CD}^{+}, \mathrm{CD}^{+} 4^{+}$e $\mathrm{CD}^{-}$(Figura 3), semelhantes a hASC (28) e cASC (70). Nesta passagem não foi observada heterogeneidade de marcadores de superfície como observado por Mitchell e colaboradores (71). A análise de viabilidade de pASC após ciclo de congelamento/descongelamento foi sempre superior a $90 \%$ para todos os criotubos testados, de acordo com os dados obtidos para este tipo celular em outras espécies $(50,51,53)$. Além disso, pASC não sofreram alterações nas suas características morfológicas nem na expressão de marcadores de superfície após descongelamento (passagens 4 e 5; Figura 6).

A cinética de crescimento de pASC durante o período avaliado (passagens 5-10) foi homogênea e constante. O tempo de dobramento de pASC foi calculado com base em curvas de crescimento (64) geradas a 
Discussão

partir de experimentos controlados. O tempo de dobramento obtido para pASC é consistente com obtido por outros $(72,73)$. Estas células apresentam uma relação linear entre o acumulado de duplicação da população e número de passagem. Estes dados indicam uma taxa constante de duplicação da população ao longo das passagens 5 a 10, conforme já observado para pASC $(73,74)$ e hASC $(29)$. Além disso, menos de $3,5 \%$ do pASC apresentaram fenótipo senescente na passagem 5 (células deixam de se dividir, morfologia alongada, forma irregular com citoplasma disperso e aparecimento de vacúolos citoplasmáticos) também semelhante a dados obtidos por Williams e colaboradores em células não congeladas (73).

Curiosamente, a cinética de crescimento de pASC frescas não diferiu da observada para pASC submetidas a ciclos de congelamento/descongelamento. Este dado permite sugerirmos a idéia de que se possa produzir um banco de células-tronco de porcos com potencial terapêutico para uso em estudos pré-clinicos.

A plasticidade das pASC descongeladas foi testada através da indução química de diferenciação. A morfologia de pASC foi alterada quando estas células foram submetidas a adipogênese. Durante três semanas de tratamento, as células apresentaram morfologia estendida e acúmulo de gotículas lipídicas no citopoplasma. No entanto, este evento sempre foi reduzido a pequenas regiões espalhadas por toda a placa de cultura (Figura 15). Comparado com o hASC (Figura 17) $(23,28)$ as gotículas lipídicas obtidas em pASC eram menores e escassas, dificultando a visualização e posterior coloração das mesmas. 
Discussão

A indução osteogênica resultou na alteração de morfologia de pASC quando comparadas com o controle negativo. Nódulos mineralizados corados pelo vermelho de alizarina foram observados, assim como em hASC $(23,28)$ e outros trabalhos com porcos $(72,75)$. Como observado na indução adipogênica, esse padrão de nódulos mineralizados foram observados apenas em algumas áreas da placa (Figura 19). Esta peculiaridade experimental observada pode sugerir que algumas células têm maior plasticidade do que outras em uma mesma população (76).

Células-tronco mesenquimais derivadas do tecido adiposo foram isoladas e caracterizadas pela primeira vez por Zuk e colaboradores $(23,40)$ em humano submetidos à lipoaspiração cirurgia estética. $\mathrm{O}$ isolamento de células-tronco do tecido adiposo permite a extração de várias regiões do corpo com o mínimo de desconforto para o paciente, além disso, a quantidade de células-tronco que podem ser obtidas do tecido adiposo é superior à obtida em extração da medula óssea (23). Essas células foram capazes de se diferenciar, por indução química, em células das linhagens adipogênica, osteogênica, condrogênica e miogênica demonstrando sua plasticidade. Após o isolamento e caracterização de ASC em humanos, outros animais como ratos (77), coelhos (78), camundongos (79), cães (80) e porcos (75) têm sido utilizados como fonte de ASC.

O porco é um interessante modelo pré-clínico para o estudo de doenças cardiovasculares $(17,18)$, sendo assim um modelo importante para testar abordagens terapêuticas. Células-tronco têm sido extensamente testadas como tratamento alternativo e complementar para uma variedade 
Discussão

de doenças incluindo a reparação cardíaca após infarto do miocárdio (9, 10, 16, 81). Considerando a falta de evidências robustas para transdiferenciação de cardiomiócitos, a melhora de função cardíaca observada até aqui tem sido atribuída a efeitos secundários relacionados à liberação de fatores de crescimento, pró-angiogênicos e anti-apoptóticos pelas células transplantadas $(13,14,82)$. A variedade de citocinas e proteases normalmente liberadas no microambiente do infarto ou peri-infarto colaboram para uma melhora global do coração e podem estar sendo potenciadas pelo transplante de células-tronco $(5,7)$.

Neste trabalho além de caracterizarmos as pASC criopreservadas, testamos a hipótese de que o SS pode diferenciar ou ao menos modificar funcionalmente estas células para o fenótipo endotelial in vitro. Para tanto, pASC foram submetidas a diferentes intensidades de SS em sistema de viscometro, o qual demonstrou anteriormente ser um sitema capaz de induzir alinhamento de células endoteliais de porcos (83) e células embrionárias mesenquimais progenitoras de murinos (84). No entanto, tal indução não foi observada em hASC (27), a despeito destas células apresentarem outras caracteristicas funcionais compativeis com um perfil de células endoteliais.

Nossos dados demonstraram que pASC sofrem alterações morfológicas tendendo ao alinhamento, mas curiosamente essa alteração ocorre perpendicularmente ao fluxo. Já foi observado que células endoteliais quando em placas de cultura subconfluentes, tendem ao alinhamento perpendicular ao fluxo (85), o que poderia explicar o evento observado. Nós também observamos que a intensidade $\left(5,10\right.$ e 15 dyn/ $\left.\mathrm{cm}^{2}\right)$ e tempo (24 e 
Discussão

48 horas) que pASC são submetidas ao SS parece estar relacionada com as alterações morfológicas observadas nas células estímulas (fusiforme) versus as células em condição estática (fibroblastos-like) (Figura 20). Apesar de as pASC apresentarem alterações morfológicas após o SS, marcadores endoteliais como CD31, VE-caderina e FLK-1 não foram detectados nestas células.

O FLK-1 ou KDR é uma proteína transmembrana que atua como um dos receptores de VEGF em células endoteliais. A proteína VE-caderina ou CDH5, é responsável por realizar conexão e, desta maneira, auxilia as células endoteliais na ancoragem e ligação intercelular. Outra proteína característica de superfície de células endoteliais é a PECAM-1 ou CD31, que atua como molécula de adesão encontrada em junções intercelulares. Trabalhos na literatura demonstraram que células-tronco submetidas a SS associadas a estímulos químicos passam a expressar essas proteínas características de células endoteliais $(62,63)$.

Nas condições experimentais ensaiadas, o SS não induziu alterações nos padrões de marcadores de superfície tipicamente mesenquimais (CD29, CD90 e CD44), sugerindo que o SS isoladamente não é suficiente para induzir a diferenciação endotelial de pASC, assim como observado anteriormente para hASC (27).

A despeitos dos resultados obtidos com estimulos físicos em hASC e agora pASC, o sinergismo entre SS e estímulos químicos tem sido apresentado por outros grupos de pesquisadores como uma solução para a 
Discussão

indução de marcadores endoteliais em células-tronco adultas. hASC prétratadas por três semanas com meio de cultura suplementado (ECGS) em sinergismo com SS por até 8 dias, foram capazes de formar conexões em Matrigel, incorporar LDL acetilado e expressar o marcador CD31 (62). Em outro estudo, células-tronco de pacientes idosos, cultivadas em meio de cultura de crescimento endotelial (EGM-2, Lonza) suplementado com VEGF, quando submetidas a SS foram capazes de incorporar LDL acetilado e lectina, expressar CD31 e, além disso, expressar outros marcadores endoteliais como VWF, VE-caderina e eNOS (63).

Embora não tenhamos encontrado evidências para a diferenciação endotelial de pASC, com base em marcadores de superfície celular e perfis de expressão gênica e protéica, observamos que estas células sofreram alterações funcionais quando submetidas a SS. Detectamos inicialmente um aumento na liberação de óxido nítrico (NO) em meio condicionado, conforme previamente demonstrado para células endoteliais $(86,87)$ e hASC $(27)$.

O NO é uma molécula importante na sinalização intra e extracelular e apresenta entre outras funções, uma potente ação vaso dilatadora agindo sobre o endotelio vascular (88). O NO é produzido por enzimas chamadas de óxido nítrico sintetases (do inglês, NOS). Esta enzima podem ser encontrada em três isoformas em mamíferos. A NOS induzível (iNOS), que leva este nome por ter sido isolada inicialmente em macrófagos imunoativados, a NOS neuronal (nNOS) isolada inicialmente em tecidos neuronais e a NOS endotelial (eNOS) principalmente em células endoteliais, 
Discussão

mas também encontrada em cardiomiócitos, plaquetas, células do hipocampo cerebral entre outros tecidos (89).

Existem evidências que apoiam a produção de NO mediada por iNOS em hASCs induzidas a diferenciar-se em condrócitos (90) ou influenciando a proliferação de células T (91). Em hASC submetidas a SS, a unica isoforma NOS detectada e em baixa quantidade, foi a eNOS (27). , deste modo, acreditamos que o mesmo mecanismo pode estar envolvido na regulação de liberação de NO em pASC sob SS. No entanto, devido a dificuldades técnicas, como a obtenção de anticorpos ou mesmo primers para esta espécie (porco), experimentos mais aprofundados como análise de proteínas da NOS não foram desenvolvidos até o presente momento.

Observamos também que as pASC submetidas ao SS sofreram aumento da liberação de VEGF. Observamos em experimentos realizados em um sistema de cone-plate para placas de $10 \mathrm{~cm}$, a $15 \mathrm{dyn} / \mathrm{cm}^{2}$ de SS, que a taxa de produção de VEGF não é constante. Acreditamos que isso se deve a questões técnicas relacionadas com o sistema, já que para manter as células por 48 horas sob estímulo este sistema deve ser desligado a cada 24 horas para reposição de meio de cultura, devido à evaporação do mesmo neste período. Especulamos que a parada repentina seguida do religamento do sistema de SS (intervalo de 15 minutos entre desligamento e religamento) possa dar um estímulo extra para liberação de VEGF, no período de parada. Tal fenômeno não foi observado nos experimentos de longa duração em sistema de SS para placas de $15 \mathrm{~cm}$, onde a evaporação é bem menos importante ao longo do tempo e o sistema não precisa ser desligado para 
Discussão

reposição de meio de cultura. Contudo esse fenômeno precisa ser mais bem investigado.

Outra observação curiosa é que a produção de VEGF em pASC é superior ao observado para hASC (27). Após 96 horas de SS, cinco vezes mais VEGF foi detectado em meio condicionado que o observado anteriormente para hASC em mesmas condições experimentais (27). Provavelmente esse evento deve-se a diferenças entre espécies, já que pASC em condições basais apresentaram níveis de produção de VEGF superiores quando comparadas com hASC verificado por nós e por outros (27, 92), o que por si explicaria as diferenças observadas sob SS. Além disso, nós também observamos que após 72 horas sob SS, cerca de $75 \%$ da produção do VEGF foi inibida, quando 1mM L-NAME (Figura 25), de maneira similar ao observado anteriormente para hASC (27).

O VEGF é um fator de crescimento vascular produzido por uma ampla gama de células (93), incluindo macrófagos, células musculares lisas vasculares, pericitos, fibroblastos, queratinócitos, células tumorais, linfócitos, megacariocitos, neutrófilos, basófilos, mastócitos, astrócitos, células-tronco mesenquimais derivadas de medula óssea (MSC) (94) e hASC (27). Este fator é um importante mediador de permeabilidade vascular processos de angiogênese e inflamação intimamente envolvido na reparação de tecidos, levando à formação de novos vasos sanguíneos $(95,96)$. Em cultura de células endoteliais não estimuladas, a Ser1177 de eNOS não é fosforilada, enquanto que esta serina sofre fosforilação quando submetida a SS (97) ou tratamento com VEGF (98). As quinases envolvidas nestes processos 
Discussão

variam de acordo com os estímulos aplicados. Por exemplo, o SS provoca a fosforilação da Ser1177 via PKA, já o VEGF age via Akt (99). FLK-1, um dos receptores de VEGF, não é observado em hASC, mas o SS fosforila Akt, consistentemente com a via de ativação de eNOS (27). Nós não identificamos FLK-1 em pASC estáticas ou sob SS. Depois de demonstrada, em condições fisiológicas de SS (15 dyn/ $\mathrm{cm}^{2}$ ), a produção de VEGF mediada por NO em pASC, e baseados em dados da literatura que apontam para uma relação na via de sinalização entre ERK/AKT/eNOS (100), testamos a hipotese de que diferentes magnitudes de SS, em diferentes tempos de estimulação, pudessem influenciar na fosforilação de ERK e AKT e então na produção e liberação de NO. Quando submetidas a diferentes intensidade de SS $(1-3,5,15$ e 25-30 dyn/cm² ) por um curto período de tempo (30 minutos) resultaram em comparável indução de fosforilação de ERK e AKT e liberação de óxido nítrico versus os controles com células estáticas (Figura 29, 30 e 31). Apesar de não termos avaliado eNOS, os dados obtidos em nosso laboratório para hASC (27) somados a fosforilação de ERK a AKT sugerem fortemente que o SS ativa eNOS por esta via também em pASC.

Apesar de não termos obtido diferenças significativas na fosforilação de ERK e AKT com diferentes magnitudes de SS em 30 minutos, a literatura demonstra que células progenitoras $\mathrm{FLK}-1^{+}$derivadas de células-tronco embrionárias, submetidas a diferentes intensidade de SS (1,5 e 5 dyn/cm²) por ao menos após 48, apresentam diferença estatisticamente significativa 
Discussão

entre a expressão gênica de FLK-1, Flt-1 e PECAM-1 entre outros genes (101).

Deste modo, foi avaliada a liberação de NO e VEGF em pASC submetidas a SS por 24 e 48 horas a 5, 10 e 15 dyn/ $/ \mathrm{cm}^{2}$ de SS. Nestas condições, a liberação de NO foi significativamente maior nas células submetidas a $5 \mathrm{dyn} / \mathrm{cm}^{2}$ versus as à 10 e 15 dyn/cm² (Figura 32A). Considerando essa diferença observada na liberação de NO, avaliamos a liberação de VEGF. Nossos dados demonstram que a produção de VEGF foi alterada nessas condições, dependentemente do aumento da liberação de NO em diferentes magnitudes de SS (5 dyn/cm² versus 10, $15 \mathrm{dyn} / \mathrm{cm}^{2}$; Figura 32B). Estes dados sugerem que a intensidade SS e tempo de estimulo, de fato, tem influência sob a liberação de NO e VEGF nessas células, no entanto, ainda não está claro qual o mecanismo envolvido neste processo biológico.

Dados de nosso laboratório mostram que fibroblastos geneticamente modificados para expressar VEGF injetados no coração de rato isquêmico estão associados com a preservação da função cardíaca destes animais e isso não é observado para injeção fibroblastos não modificados (102). Também já demonstramos que injeções intramiocárdicas de células-tronco mesenquimais derivadas da medula óssea ou tecido adiposo de ratos resultam na preservação do desempenho cardíaco de animais isquêmicos $(9,10,16)$. 
Discussão

Dados da literatura corroboram que as células-tronco quando submetidas a diferentes estímulos químico/farmacológicos e/ou físicos, in vitro e in vivo são capazes de responder e expressar a uma série de fatores solúveis $(57,103-106)$, os quais podem estar relacionados com a melhora de orgãos submetidos a terapias com estas células, senão explicar boa parte do efeito. Neste contexto, o estudo de NO e o VEGF, faz-se importante, uma vez que estes fatores estão relacionados com a formação de novos vasos e em vias de sinalização celular que possivelmente estão ocorrendo no coração infartado. 
6. Conclusões 


\subsection{Conclusões Sumarizadas}

a) A extração foi padronizada resultando um procedimento reprodutível capaz de isolar grandes quantidades viáveis de pASC de pequenas quantidades de tecido adiposo;

b) Um banco de células de aproximadamente 3 bilhões de pASC foi gerado tendo estas células a viabilidade celular preservada após descongelamento;

c) As pASC criopreservadas mantiveram suas características morfológicas, de crescimento e plasticidade quando comparadas com células não submetidas ao congelamento;

d) O uso do sistema de cone-plate para mimetizar de SS em culturas de pASC foi reprodutível;

e) As pASC responderam ao SS com alterações morfológica e funcionais, mas não imunofenotípicas. 
Conclusões

\subsection{Conclusão Final}

Tomados em conjunto, os dados obtidos neste estudo fornecem evidências de que viabilidade celular, morfologia, características de crescimento e a capacidade de responder a estímulos químicos ou físicos não foram influenciados pelo longo prazo de congelamento de pASC nas condições de armazenamento utilizadas, o que pode ser importante à considerar uma proposta de uso de um banco de célula-tronco como ferramenta para fins terapêuticos. Além disso, a magnitude do SS afeta a liberação de NO e VEGF nestas células, quando estas são submetidas a longos períodos de exposição a este estímulo físico. 
7. Anexos 
Anexos

Anexo A - Cópia do parecer de aprovação do Comitê de Ética para Análise de projetos de Pesquisa - CAPPesq.

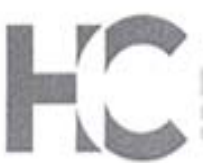

UDSPTHL BAS BLIMHES

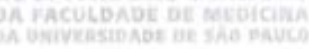

\section{APROVAÇÃO}

A Comissão de Ética para Análise de Projetos de Pesquisa CAPpesq da Diretoria Clinica do Hospital das Clínicas e da Faculdade de Medicina da Universidade de São Paulo, em sessão de 04/02/2009. APROVOU O Protocolo de Pesquisa $n^{\circ}$ 0022/09, intitulado: "ESTUDO DO EFEITO dO IMPLANTE CARdíaCO DE FIBROBLASTOS GENETICAMENTE MODIFICADOS PARA EXPRESSAR VEGF EM CORAÇÃO DE SUÍNOS INFARTADOS - AVALIAÇÃO SOBRE A ANGIOGÊNESE E A FUNÇÃO CARDÍACA." apresentado pelo Departamento de COMISSÃO CIENTíFICA DO INCOR.

Cabe ao pesquisador elaborar e apresentar à CAPPesq. os relatórios parciais e final sobre a pesquisa (Resolução do Conselho Nacional de Saúde n 196, de 10/10/1996, inciso IX.2, letra "c").

Pesquisador (a) Responsável: Prof. Dr. José Eduardo Krieger Pesquisador (a) Executante: Rafael Dariolli

CAPPesq, 04 de Fevereiro de 2009

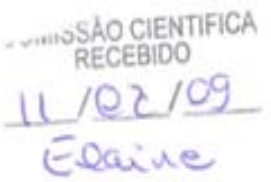

Prof. Dr. Eduardo Massad Presidente da Comissäo de Ética para Análise de Projetos de Pesquisa

Comissdo de Ética para Análise de Projetos de Pesquisa do HCFMUSP e da FMUSP Diretoria Clinica do Hospital das Clinicas da Faculdade de Medicina da Universidade de Såo Paulo Rua Ovidio Pires de Campos. 225, $5^{\circ}$ andar - CEP 05403010 - Såo Paulo - SP Fone: 01130696442 Fax 01130696492 e-mail: cappesq@henet usp. br / secretariacappesq2@hcnet. usp.br 
Anexos

Anexo B - Cópia do parecer de aprovação para adição de subprojeto no processo 0022/09, pelo Comitê de Ética para Análise de projetos de Pesquisa - CAPPesq.

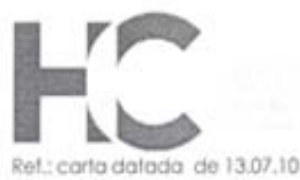

A

Comissão Científica

Incor

O Presidente da Comissăo de Ética para Análise de Projetos de Pesquisa - CAPPesa da Diretoria Clinica do Hospital das Clinicas e da Faculdade de Medicina da Universidade de São Paulo, em 08.09.10, tomou conhecimento que o Protocolo de Pesquisa $n^{\circ}$ 0022/09. intitulado: "Estudo Do Efeito Do Implante Cardíaco De Fibroblastos Geneficamente Modificados Para Expressar VEGF Em Coraçāo De Suínos Infartados - Avaliação Sobre A Angiogênese E A Função Cardíaca.". contempla o sub-projeto intitulado "Estudo do efeito do implante alogênico de células-tronco mesenquimais derivadas do tecido adiposo em coraçāo de suínos infartados - Avaliaçāo sobre a angiogênese e a função cardíaca", o qual será executado pelo aluno Rafael Dariolli. Bem como a prorrogaçāo da data de término previsto de 08/2010 para 08/2014 e relatório parcial.

CAPPesq, 10 de Setembro de 2010

Prof. Dr. Eduardo Massad Presidente da Comissão

COMISSAO CIENTIFICA RECEBIDO $\frac{14}{109} 1 \frac{10}{1000}$

Comissho de Etica para Andilise de Projetos de Pesquisa do HCrMUSP e da Fmusp Diretoria Clinica do Hospitat das Clinicas da Faculdade de Medicina da Universidade de Sa Paulo Rua Ovidio Pires de Campos. 225, 5 " andar - CEP 05430010 - 5áo Paulo + \$P

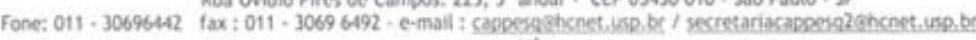
de Ética para Análise de Projetos de Pesquisa 


\section{Referências Bibliográficas}


Referências Bibliográficas

1. OMS. 2008 [atualizado em 2008; acessado em 16/05/2011]; Web URL: http://www.who.int/healthinfo/morttables/en/index.html.

2. MS D-MdS. Taxa de mortalidade específica por doenças do aparelho circulatório. 2008 [Atualizado em 2008; acessado em 16/05/2011]; Sistema de Informações sobre Mortalidade - SIM]. Web URL: http://tabnet.datasus.gov.br/cgi/deftohtm.exe?idb2009/c08.def.

3. Balsam LB, Wagers AJ, Christensen JL, Kofidis T, Weissman IL, Robbins RC. Haematopoietic stem cells adopt mature haematopoietic fates in ischaemic myocardium. Nature. 2004 Apr 8;428(6983):668-73.

4. Chen D, McKearin D. Gene circuitry controlling a stem cell niche. Curr Biol. 2005 Jan 26;15(2):179-84.

5. Kinnaird T, Stabile E, Burnett MS, Lee CW, Barr S, Fuchs S, et al. Marrow-derived stromal cells express genes encoding a broad spectrum of arteriogenic cytokines and promote in vitro and in vivo arteriogenesis through paracrine mechanisms. Circ Res. 2004 Mar 19;94(5):678-85.

6. Nygren JM, Jovinge S, Breitbach M, Sawen P, Roll W, Hescheler J, et al. Bone marrow-derived hematopoietic cells generate cardiomyocytes at a low frequency through cell fusion, but not transdifferentiation. Nat Med. 2004 May;10(5):494-501.

7. Wollert KC, Drexler $\mathrm{H}$. Clinical applications of stem cells for the heart. Circ Res. 2005 Feb 4;96(2):151-63.

8. Xie T, Kawase E, Kirilly D, Wong MD. Intimate relationships with their neighbors: tales of stem cells in Drosophila reproductive systems. Dev Dyn. 2005 Mar;232(3):775-90.

9. Danoviz ME, Nakamuta JS, Marques FL, dos Santos L, Alvarenga EC, dos Santos AA, et al. Rat adipose tissue-derived stem cells transplantation 
Referências Bibliográficas

attenuates cardiac dysfunction post infarction and biopolymers enhance cell retention. PLoS One. 2010;5(8):e12077.

10. Nakamuta JS, Danoviz ME, Marques FL, dos Santos L, Becker C, Goncalves GA, et al. Cell therapy attenuates cardiac dysfunction post myocardial infarction: effect of timing, routes of injection and a fibrin scaffold. PLoS One. 2009;4(6):e6005.

11. Kudo M, Wang Y, Wani MA, Xu M, Ayub A, Ashraf M. Implantation of bone marrow stem cells reduces the infarction and fibrosis in ischemic mouse heart. J Mol Cell Cardiol. 2003 Sep;35(9):1113-9.

12. Orlic D, Kajstura J, Chimenti S, Jakoniuk I, Anderson SM, Li B, et al. Bone marrow cells regenerate infarcted myocardium. Nature. 2001 Apr 5;410(6829):701-5.

13. Gimble JM, Katz AJ, Bunnell BA. Adipose-derived stem cells for regenerative medicine. Circ Res. 2007 May 11;100(9):1249-60.

14. Kilroy GE, Foster SJ, Wu X, Ruiz J, Sherwood S, Heifetz A, et al. Cytokine profile of human adipose-derived stem cells: expression of angiogenic, hematopoietic, and pro-inflammatory factors. J Cell Physiol. 2007 Sep;212(3):702-9.

15. Rehman J, Traktuev D, Li J, Merfeld-Clauss S, Temm-Grove CJ, Bovenkerk JE, et al. Secretion of angiogenic and antiapoptotic factors by human adipose stromal cells. Circulation. 2004 Mar 16;109(10):1292-8.

16. Dos Santos L, Santos AA, Goncalves GA, Krieger JE, Tucci PJ. Bone marrow cell therapy prevents infarct expansion and improves border zone remodeling after coronary occlusion in rats. Int J Cardiol. 2009 Jul 2.

17. Hughes GC, Post MJ, Simons M, Annex BH. Translational physiology: porcine models of human coronary artery disease: implications for preclinical trials of therapeutic angiogenesis. J Appl Physiol. 2003 May;94(5):1689-701. 
Referências Bibliográficas

18. Hughes HC. Swine in cardiovascular research. Lab Anim Sci. 1986 Aug;36(4):348-50.

19. Brehm M, Zeus T, Strauer BE. Stem cells--clinical application and perspectives. Herz. 2002 Nov;27(7):611-20.

20. Zipori D. Mesenchymal stem cells: harnessing cell plasticity to tissue and organ repair. Blood Cells Mol Dis. 2004 Nov-Dec;33(3):211-5.

21. Alison MR, Poulsom R, Forbes $S$, Wright NA. An introduction to stem cells. J Pathol. 2002 Jul;197(4):419-23.

22. Alberts B BD, Lewis J, Raff M, Roberts K, Watson JD. Molecular Biology of the Cell. $3^{\circ}$ ed, editor. New York; 1994.

23. Zuk PA, Zhu M, Ashjian P, De Ugarte DA, Huang Jl, Mizuno $\mathrm{H}$, et al. Human adipose tissue is a source of multipotent stem cells. Mol Biol Cell. 2002 Dec;13(12):4279-95.

24. Dudas JR, Marra KG, Cooper GM, Penascino VM, Mooney MP, Jiang $\mathrm{S}$, et al. The osteogenic potential of adipose-derived stem cells for the repair of rabbit calvarial defects. Ann Plast Surg. 2006 May;56(5):543-8.

25. Farrell E, Both SK, Odorfer KI, Koevoet W, Kops N, O'Brien FJ, et al. In-vivo generation of bone via endochondral ossification by in-vitro chondrogenic priming of adult human and rat mesenchymal stem cells. BMC Musculoskelet Disord. 2011;12:31.

26. Colter DC, Class R, DiGirolamo CM, Prockop DJ. Rapid expansion of recycling stem cells in cultures of plastic-adherent cells from human bone marrow. Proc Natl Acad Sci U S A. 2000 Mar 28;97(7):3213-8.

27. Bassaneze V, Barauna VG, Lavini-Ramos C, Kalil J, Schettert IT, Miyakawa $A A$, et al. Shear stress induces nitric oxide-mediated vascular 
Referências Bibliográficas

endothelial growth factor production in human adipose tissue mesenchymal stem cells. Stem Cells Dev. 2010 Mar;19(3):371-8.

28. Blande IS, Bassaneze V, Lavini-Ramos C, Fae KC, Kalil J, Miyakawa AA, et al. Adipose tissue mesenchymal stem cell expansion in animal serumfree medium supplemented with autologous human platelet lysate. Transfusion. 2009 Dec;49(12):2680-5.

29. Danoviz ME, Bassaneze V, Nakamuta JS, Santos-Junior GR, SaintClair D, Bajgelman MC, et al. Adipose tissue-derived stem cells from humans and mice differ in proliferative capacity and genome stability in long-term cultures. Stem Cells Dev. 2010 Aug 10.

30. Fraser JK, Schreiber RE, Zuk PA, Hedrick MH. Adult stem cell therapy for the heart. Int J Biochem Cell Biol. 2004 Apr;36(4):658-66.

31. Reyes $M$, Lund $T$, Lenvik $T$, Aguiar $D$, Koodie $L$, Verfaillie $C M$. Purification and ex vivo expansion of postnatal human marrow mesodermal progenitor cells. Blood. 2001 Nov 1;98(9):2615-25.

32. Reyes M, Verfaillie CM. Characterization of multipotent adult progenitor cells, a subpopulation of mesenchymal stem cells. Ann N Y Acad Sci. 2001 Jun;938:231-3; discussion 3-5.

33. Morel F, Szilvassy SJ, Travis M, Chen B, Galy A. Primitive hematopoietic cells in murine bone marrow express the CD34 antigen. Blood. 1996 Nov 15;88(10):3774-84.

34. Rickard DJ, Kassem M, Hefferan TE, Sarkar G, Spelsberg TC, Riggs $\mathrm{BL}$. Isolation and characterization of osteoblast precursor cells from human bone marrow. J Bone Miner Res. 1996 Mar;11(3):312-24.

35. Krampera M, Glennie S, Dyson J, Scott D, Laylor R, Simpson E, et al. Bone marrow mesenchymal stem cells inhibit the response of naive and 
Referências Bibliográficas

memory antigen-specific T cells to their cognate peptide. Blood. 2003 May 1;101(9):3722-9.

36. Murry CE, Soonpaa $M H$, Reinecke $H$, Nakajima $H$, Nakajima $H O$, Rubart $\mathrm{M}$, et al. Haematopoietic stem cells do not transdifferentiate into cardiac myocytes in myocardial infarcts. Nature. 2004 Apr 8;428(6983):6648.

37. Anversa P, Sussman MA, Bolli R. Molecular genetic advances in cardiovascular medicine: focus on the myocyte. Circulation. 2004 Jun $15 ; 109(23): 2832-8$.

38. Hattori H, Sato M, Masuoka K, Ishihara M, Kikuchi T, Matsui T, et al. Osteogenic potential of human adipose tissue-derived stromal cells as an alternative stem cell source. Cells Tissues Organs. 2004;178(1):2-12.

39. Tholpady SS, Katz AJ, Ogle RC. Mesenchymal stem cells from rat visceral fat exhibit multipotential differentiation in vitro. Anat Rec A Discov Mol Cell Evol Biol. 2003 May;272(1):398-402.

40. Zuk PA, Zhu M, Mizuno H, Huang J, Futrell JW, Katz AJ, et al. Multilineage cells from human adipose tissue: implications for cell-based therapies. Tissue Eng. 2001 Apr;7(2):211-28.

41. Lee RH, Kim B, Choi I, Kim H, Choi HS, Suh K, et al. Characterization and expression analysis of mesenchymal stem cells from human bone marrow and adipose tissue. Cell Physiol Biochem. 2004;14(4-6):311-24.

42. Di Nicola M, Carlo-Stella C, Magni M, Milanesi M, Longoni PD, Matteucci $P$, et al. Human bone marrow stromal cells suppress T-lymphocyte proliferation induced by cellular or nonspecific mitogenic stimuli. Blood. 2002 May 15;99(10):3838-43.

43. Liu J, Lu XF, Wan L, Li YP, Li SF, Zeng LY, et al. Suppression of human peripheral blood lymphocyte proliferation by immortalized 
Referências Bibliográficas

mesenchymal stem cells derived from bone marrow of Banna Minipig inbredline. Transplant Proc. 2004 Dec;36(10):3272-5.

44. Tse WT, Pendleton JD, Beyer WM, Egalka MC, Guinan EC. Suppression of allogeneic T-cell proliferation by human marrow stromal cells: implications in transplantation. Transplantation. 2003 Feb 15;75(3):389-97.

45. Bartholomew A, Sturgeon C, Siatskas M, Ferrer K, Mclntosh K, Patil $S$, et al. Mesenchymal stem cells suppress lymphocyte proliferation in vitro and prolong skin graft survival in vivo. Exp Hematol. 2002 Jan;30(1):42-8.

46. Poh KK, Sperry E, Young RG, Freyman T, Barringhaus KG, Thompson CA. Repeated direct endomyocardial transplantation of allogeneic mesenchymal stem cells: safety of a high dose, "off-the-shelf", cellular cardiomyoplasty strategy. Int J Cardiol. 2007 May 2;117(3):360-4.

47. McIntosh K, Zvonic S, Garrett S, Mitchell JB, Floyd ZE, Hammill L, et al. The immunogenicity of human adipose-derived cells: temporal changes in vitro. Stem Cells. 2006 May;24(5):1246-53.

48. McIntosh KR, Lopez MJ, Borneman JN, Spencer ND, Anderson PA, Gimble JM. Immunogenicity of allogeneic adipose-derived stem cells in a rat spinal fusion model. Tissue Eng Part A. 2009 Sep;15(9):2677-86.

49. Puissant B, Barreau C, Bourin P, Clavel C, Corre J, Bousquet C, et al. Immunomodulatory effect of human adipose tissue-derived adult stem cells: comparison with bone marrow mesenchymal stem cells. Br J Haematol. 2005 Apr;129(1):118-29.

50. Lee JE, Kim I, Kim M. Adipogenic differentiation of human adipose tissue-derived stem cells obtained from cryopreserved adipose aspirates. Dermatol Surg. 2010 Jul;36(7):1078-83.

51. Martinello T, Bronzini I, Maccatrozzo L, Mollo A, Sampaolesi M, Mascarello $F$, et al. Canine adipose-derived-mesenchymal stem cells do not 
Referências Bibliográficas

lose stem features after a long-term cryopreservation. Res Vet Sci. 2010 Aug 21.

52. Ock SA, Rho GJ. Effect of Dimethyl sulfoxide (DMSO) on cryopreservation of porcine mesenchymal stem cells (pMSCs). Cell Transplant. 2011 Feb 3.

53. Thirumala S, Gimble JM, Devireddy RV. Evaluation of methylcellulose and dimethyl sulfoxide as the cryoprotectants in a serum-free freezing media for cryopreservation of adipose-derived adult stem cells. Stem Cells Dev. 2010 Apr;19(4):513-22.

54. Nauta AJ, Fibbe WE. Immunomodulatory properties of mesenchymal stromal cells. Blood. 2007 Nov 15;110(10):3499-506.

55. Erickson GR, Gimble JM, Franklin DM, Rice HE, Awad H, Guilak F. Chondrogenic potential of adipose tissue-derived stromal cells in vitro and in vivo. Biochem Biophys Res Commun. 2002 Jan 18;290(2):763-9.

56. Safford KM, Hicok KC, Safford SD, Halvorsen YD, Wilkison WO, Gimble JM, et al. Neurogenic differentiation of murine and human adiposederived stromal cells. Biochem Biophys Res Commun. 2002 Jun 7;294(2):371-9.

57. Estrada R, Li N, Sarojini H, An J, Lee MJ, Wang E. Secretome from mesenchymal stem cells induces angiogenesis via Cyr61. J Cell Physiol. 2009 Jun;219(3):563-71.

58. Davies PF, Robotewskyj A, Griem ML, Dull RO, Polacek DC. Hemodynamic forces and vascular cell communication in arteries. Arch Pathol Lab Med. 1992 Dec;116(12):1301-6.

59. Miyakawa AA, de Lourdes Junqueira M, Krieger JE. Identification of two novel shear stress responsive elements in rat angiotensin I converting enzyme promoter. Physiol Genomics. 2004 Apr 13;17(2):107-13. 
Referências Bibliográficas

60. Rieder MJ, Carmona R, Krieger JE, Pritchard KA, Jr., Greene AS. Suppression of angiotensin-converting enzyme expression and activity by shear stress. Circ Res. 1997 Mar;80(3):312-9.

61. Eng E, Ballermann BJ. Diminished NF-kappaB activation and PDGF-B expression in glomerular endothelial cells subjected to chronic shear stress. Microvasc Res. 2003 May;65(3):137-44.

62. Fischer LJ, Mcllhenny S, Tulenko T, Golesorkhi N, Zhang P, Larson R, et al. Endothelial differentiation of adipose-derived stem cells: effects of endothelial cell growth supplement and shear force. J Surg Res. 2009 Mar;152(1):157-66.

63. Zhang P, Moudgill N, Hager E, Tarola N, Dimatteo C, Mcllhenny S, et al. Endothelial Differentiation of Adipose-Derived Stem Cells from Elderly Patients with Cardiovascular Disease. Stem Cells Dev. 2010 Nov 1.

64. Freshney RI. Culture of Animal Cells. A Manual of Basic Technique. 4th ed. Inc JW, editor. New York, NY; 2000.

65. Dimri GP, Lee X, Basile G, Acosta M, Scott G, Roskelley C, et al. A biomarker that identifies senescent human cells in culture and in aging skin in vivo. Proc Natl Acad Sci U S A. 1995 Sep 26;92(20):9363-7.

66. Kinkel AD, Fernyhough ME, Helterline DL, Vierck JL, Oberg KS, Vance TJ, et al. Oil red-O stains non-adipogenic cells: a precautionary note. Cytotechnology. 2004 Sep;46(1):49-56.

67. Jaiswal RK, Jaiswal N, Bruder SP, Mbalaviele G, Marshak DR, Pittenger MF. Adult human mesenchymal stem cell differentiation to the osteogenic or adipogenic lineage is regulated by mitogen-activated protein kinase. J Biol Chem. 2000 Mar 31;275(13):9645-52. 
Referências Bibliográficas

68. Malek A, Izumo S. Physiological fluid shear stress causes downregulation of endothelin-1 mRNA in bovine aortic endothelium. Am J Physiol. 1992 Aug;263(2 Pt 1):C389-96.

69. Ding $\mathrm{AH}$, Nathan $\mathrm{CF}$, Stuehr DJ. Release of reactive nitrogen intermediates and reactive oxygen intermediates from mouse peritoneal macrophages. Comparison of activating cytokines and evidence for independent production. J Immunol. 1988 Oct 1;141(7):2407-12.

70. Vieira NM, Brandalise V, Zucconi E, Secco M, Strauss BE, Zatz M. Isolation, characterization, and differentiation potential of canine adiposederived stem cells. Cell Transplant. 2010;19(3):279-89.

71. Mitchell JB, Mclntosh K, Zvonic S, Garrett S, Floyd ZE, Kloster A, et al. Immunophenotype of human adipose-derived cells: temporal changes in stromal-associated and stem cell-associated markers. Stem Cells. 2006 Feb;24(2):376-85.

72. Arrigoni E, Lopa S, de Girolamo L, Stanco D, Brini AT. Isolation, characterization and osteogenic differentiation of adipose-derived stem cells: from small to large animal models. Cell Tissue Res. 2009 Dec;338(3):401-11.

73. Williams KJ, Picou AA, Kish SL, Giraldo AM, Godke RA, Bondioli KR. Isolation and characterization of porcine adipose tissue-derived adult stem cells. Cells Tissues Organs. 2008;188(3):251-8.

74. Wang $\mathrm{KH}$, Kao AP, Wangchen $\mathrm{H}$, Wang $\mathrm{FY}$, Chang $\mathrm{CH}$, Chang $\mathrm{CC}$, et al. Optimizing proliferation and characterization of multipotent stem cells from porcine adipose tissue. Biotechnol Appl Biochem. 2008 Dec;51(Pt 4):159-66.

75. Qu CQ, Zhang GH, Zhang LJ, Yang GS. Osteogenic and adipogenic potential of porcine adipose mesenchymal stem cells. In Vitro Cell Dev Biol Anim. 2007 Feb;43(2):95-100. 
Referências Bibliográficas

76. Guilak F, Lott KE, Awad HA, Cao Q, Hicok KC, Fermor B, et al. Clonal analysis of the differentiation potential of human adipose-derived adult stem cells. J Cell Physiol. 2006 Jan;206(1):229-37.

77. Yoshimura H, Muneta T, Nimura A, Yokoyama A, Koga H, Sekiya I. Comparison of rat mesenchymal stem cells derived from bone marrow, synovium, periosteum, adipose tissue, and muscle. Cell Tissue Res. 2007 Mar;327(3):449-62.

78. Rangappa S, Fen C, Lee EH, Bongso A, Sim EK. Transformation of adult mesenchymal stem cells isolated from the fatty tissue into cardiomyocytes. Ann Thorac Surg. 2003 Mar;75(3):775-9.

79. Ogawa R, Mizuno H, Watanabe A, Migita M, Shimada T, Hyakusoku $\mathrm{H}$. Osteogenic and chondrogenic differentiation by adipose-derived stem cells harvested from GFP transgenic mice. Biochem Biophys Res Commun. 2004 Jan 23;313(4):871-7.

80. Neupane M, Chang CC, Kiupel M, Yuzbasiyan-Gurkan V. Isolation and Characterization of Canine Adipose-Derived Mesenchymal Stem Cells. Tissue Eng Part A. 2008 Apr 17.

81. Mummery CL, Davis RP, Krieger JE. Challenges in using stem cells for cardiac repair. Sci Transl Med. 2010 Apr 14;2(27):27ps17.

82. Gandia C, Arminan A, Garcia-Verdugo JM, Lledo E, Ruiz A, Minana $M D$, et al. Human dental pulp stem cells improve left ventricular function, induce angiogenesis, and reduce infarct size in rats with acute myocardial infarction. Stem Cells. 2008 Mar;26(3):638-45.

83. Dieterich $\mathrm{P}$, Odenthal-Schnittler M, Mrowietz C, Kramer M, Sasse L, Oberleithner $\mathrm{H}$, et al. Quantitative morphodynamics of endothelial cells within confluent cultures in response to fluid shear stress. Biophys J. 2000 Sep;79(3):1285-97. 
Referências Bibliográficas

84. Wang H, Riha GM, Yan S, Li M, Chai H, Yang H, et al. Shear stress induces endothelial differentiation from a murine embryonic mesenchymal progenitor cell line. Arterioscler Thromb Vasc Biol. 2005 Sep;25(9):1817-23.

85. Mott RE, Helmke BP. Mapping the dynamics of shear stress-induced structural changes in endothelial cells. Am J Physiol Cell Physiol. 2007 Nov;293(5):C1616-26.

86. Berk BC, Corson MA, Peterson TE, Tseng H. Protein kinases as mediators of fluid shear stress stimulated signal transduction in endothelial cells: a hypothesis for calcium-dependent and calcium-independent events activated by flow. J Biomech. 1995 Dec;28(12):1439-50.

87. Uematsu M, Ohara Y, Navas JP, Nishida K, Murphy TJ, Alexander $R W$, et al. Regulation of endothelial cell nitric oxide synthase mRNA expression by shear stress. Am J Physiol. 1995 Dec;269(6 Pt 1):C1371-8.

88. Cohen RA, Weisbrod RM, Gericke M, Yaghoubi M, Bierl C, Bolotina VM. Mechanism of nitric oxide-induced vasodilatation: refilling of intracellular stores by sarcoplasmic reticulum $\mathrm{Ca} 2+$ ATPase and inhibition of storeoperated Ca2+ influx. Circ Res. 1999 Feb 5;84(2):210-9.

89. Michel T, Feron O. Nitric oxide synthases: which, where, how, and why? J Clin Invest. 1997 Nov 1;100(9):2146-52.

90. Mais A, Klein T, Ullrich V, Schudt C, Lauer G. Prostanoid pattern and iNOS expression during chondrogenic differentiation of human mesenchymal stem cells. J Cell Biochem. 2006 Jul 1;98(4):798-809.

91. Sato K, Ozaki K, Oh I, Meguro A, Hatanaka K, Nagai T, et al. Nitric oxide plays a critical role in suppression of T-cell proliferation by mesenchymal stem cells. Blood. 2007 Jan 1;109(1):228-34.

92. Zisa D, Shabbir A, Suzuki G, Lee T. Vascular endothelial growth factor (VEGF) as a key therapeutic trophic factor in bone marrow mesenchymal 
Referências Bibliográficas

stem cell-mediated cardiac repair. Biochem Biophys Res Commun. 2009 Dec 18;390(3):834-8.

93. Kimura $\mathrm{H}$, Esumi $\mathrm{H}$. Reciprocal regulation between nitric oxide and vascular endothelial growth factor in angiogenesis. Acta Biochim Pol. 2003;50(1):49-59.

94. Wang Y, Crisostomo PR, Wang M, Weil B, Abarbanell A, Poynter J, et al. Nitric oxide suppresses the secretion of vascular endothelial growth factor and hepatocyte growth factor from human mesenchymal stem cells. Shock. 2008 Nov;30(5):527-31.

95. Eming SA, Krieg T. Molecular mechanisms of VEGF-A action during tissue repair. J Investig Dermatol Symp Proc. 2006 Sep;11(1):79-86.

96. Pettersson A, Nagy JA, Brown LF, Sundberg C, Morgan E, Jungles S, et al. Heterogeneity of the angiogenic response induced in different normal adult tissues by vascular permeability factor/vascular endothelial growth factor. Lab Invest. 2000 Jan;80(1):99-115.

97. Dimmeler S, Fleming I, Fisslthaler B, Hermann C, Busse R, Zeiher AM. Activation of nitric oxide synthase in endothelial cells by Akt-dependent phosphorylation. Nature. 1999 Jun 10;399(6736):601-5.

98. Michell BJ, Chen Z, Tiganis T, Stapleton D, Katsis F, Power DA, et al. Coordinated control of endothelial nitric-oxide synthase phosphorylation by protein kinase C and the cAMP-dependent protein kinase. J Biol Chem. 2001 May 25;276(21):17625-8.

99. Fleming I. Molecular mechanisms underlying the activation of eNOS. Pflugers Arch. 2010 May;459(6):793-806.

100. Arroyo JA, Anthony RV, Parker TA, Galan HL. eNOS, NO, and the activation of ERK and AKT signaling at mid-gestation and near-term in an 
ovine model of intrauterine growth restriction. Syst Biol Reprod Med. Feb;56(1):62-73.

101. Yamamoto K, Sokabe T, Watabe T, Miyazono K, Yamashita JK, Obi $\mathrm{S}$, et al. Fluid shear stress induces differentiation of Flk-1-positive embryonic stem cells into vascular endothelial cells in vitro. Am J Physiol Heart Circ Physiol. 2005 Apr;288(4):H1915-24.

102. Goncalves GA, Vassallo PF, dos Santos L, Schettert IT, Nakamuta JS, Becker $\mathrm{C}$, et al. Intramyocardial transplantation of fibroblasts expressing vascular endothelial growth factor attenuates cardiac dysfunction. Gene Ther. 2010 Mar;17(3):305-14.

103. Nakagami H, Maeda $\mathrm{K}$, Morishita R, Iguchi S, Nishikawa T, Takami $\mathrm{Y}$, et al. Novel autologous cell therapy in ischemic limb disease through growth factor secretion by cultured adipose tissue-derived stromal cells. Arterioscler Thromb Vasc Biol. 2005 Dec;25(12):2542-7.

104. Wei X, Du Z, Zhao L, Feng D, Wei G, He Y, et al. IFATS collection: The conditioned media of adipose stromal cells protect against hypoxiaischemia-induced brain damage in neonatal rats. Stem Cells. 2009 Feb;27(2):478-88.

105. Zvonic S, Lefevre M, Kilroy G, Floyd ZE, DeLany JP, Kheterpal I, et al. Secretome of primary cultures of human adipose-derived stem cells: modulation of serpins by adipogenesis. Mol Cell Proteomics. 2007 Jan;6(1):18-28.

106. Quevedo HC, Hatzistergos KE, Oskouei BN, Feigenbaum GS, Rodriguez JE, Valdes $\mathrm{D}$, et al. Allogeneic mesenchymal stem cells restore cardiac function in chronic ischemic cardiomyopathy via trilineage differentiating capacity. Proc Natl Acad Sci U S A. 2009 Aug 18;106(33):14022-7. 
Apêndices 
Apêndices

Apêndice I - Cópia da confirmação de submissão do artigo resultante desta dissertação na revista Stem Cells and Development.

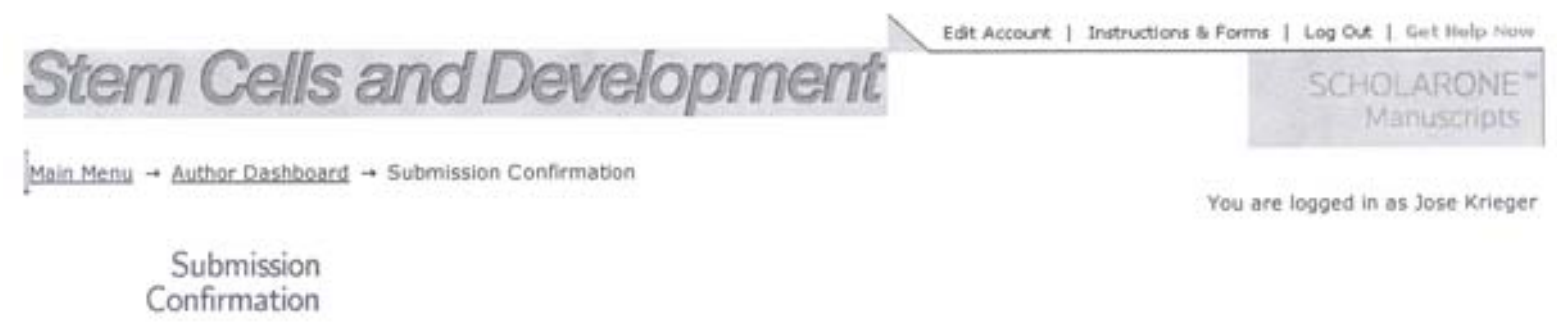

Thank you for submitting your manuscript to Stem Cells and Development.

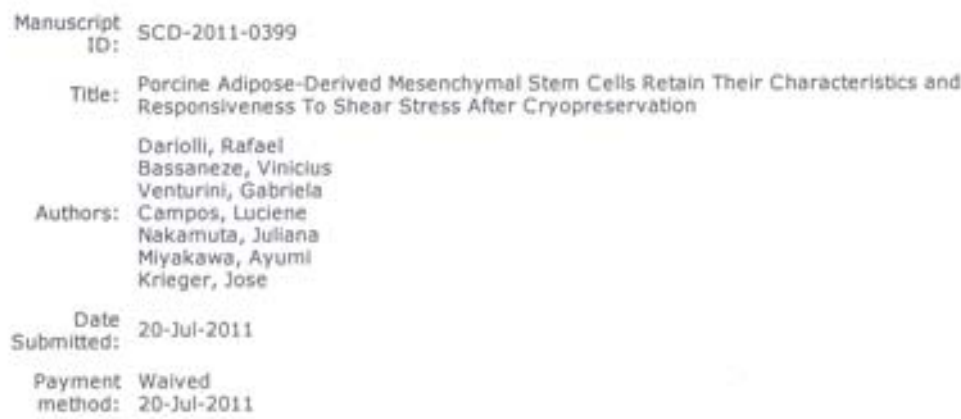

